\title{
DALLAH: THE DEATH KNELL FOR DEFERENCE?
}

\author{
BY
}

\section{ANASTASIA LEE FRASER}

\begin{abstract}
A dissertation
submitted to the Victoria University of Wellington

in partial fulfilment of the requirements for the degree of Master of Laws
\end{abstract}

Victoria University of Wellington

(2014) 
Acknowledgement ..................................................................................................................................... 3

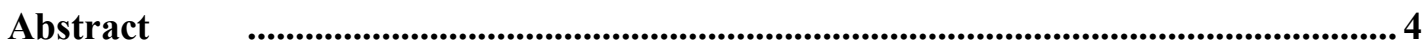

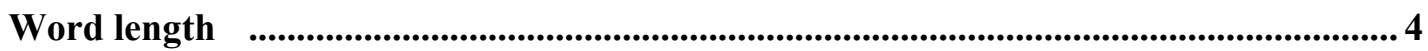

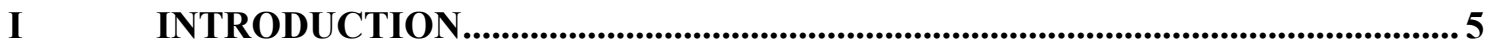

II DALLAH IN CONTEXT: THE BORDERS BETWEEN COURTS AND ARBITRATION ............................................................................................. 10

A The Nature of Arbitration ............................................................................... 11

B The International Legal Framework for Recognition and Enforcement............... 13

C The Relationship between Courts and Tribunals in the International

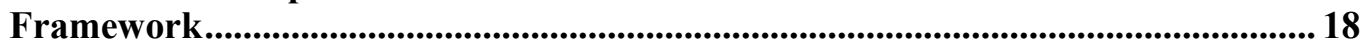

1 The role of the tribunal ........................................................................... 19

2 The function of the court......................................................................... 21

III THE PROCEEDINGS .................................................................................................. 25

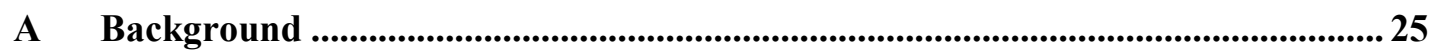

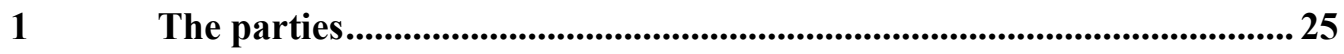

$2 \quad$ Memorandum of Understanding.................................................................... 25

3 Establishment of the Awami Hajj Trust..................................................... 26

$4 \quad$ Agreement between Dallah and the Awami Hajj Trust ........................... 27

5 Performance .......................................................................................... 28

B Proceedings before the National Courts of Pakistan and Reference to Arbitration ................................................................................................................................. 28

C Proceedings before the Arbitral Tribunal ........................................................................ 31

D Proceedings under the New York Convention ..................................................... 35

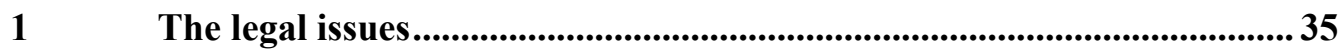

2 The decision of the English courts............................................................... 39

$3 \quad$ Proceedings before Paris Cour d'Appel .....................................................40

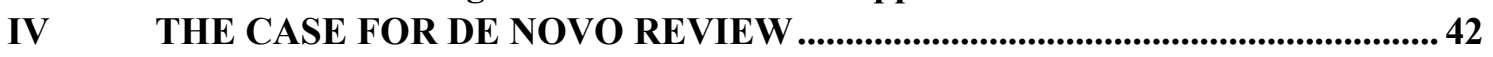

A Approach to Interpretation of the New York Convention .......................................43

$1 \quad$ Statutory interpretation ....................................................................................... 43

$2 \quad$ Relevance of cases decided under section 67 Arbitration Act 1996 (UK)......................................................................................................................5 50

B Response to Dallah's Core Arguments on the Scope of Enquiry.............................55

$1 \quad$ No primacy to court at the arbitral seat .........................................................56

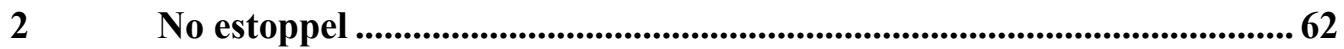

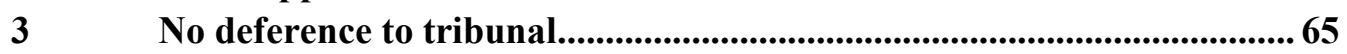

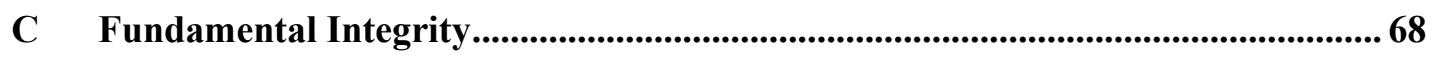

$V$ THE EXISTENCE (OR NOT) OF AN AGREEMENT TO ARBITRATE .......... 72

A Deciding the applicable law................................................................................................ 73

B Applying the law - "same same but different?"................................................... 74

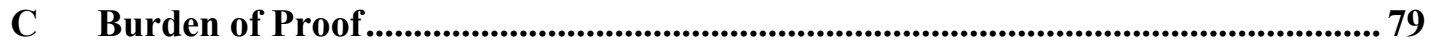

VI ALTERNATIVES TO DE NOVO REVIEW .......................................................... 83

A A pathological result? ................................................................................................. 83

B The options for judicial decision making ......................................................................... 87 


\begin{tabular}{|c|c|c|}
\hline \multirow{6}{*}{$\mathbf{C}$} & 1 & 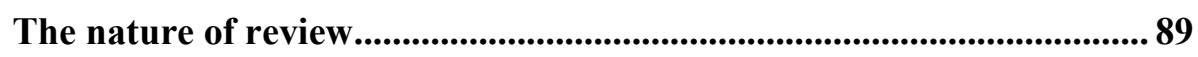 \\
\hline & 2 & 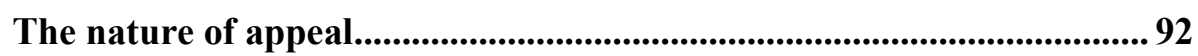 \\
\hline & Di & t approaches under the English Arbitration Act 1996.............................. 93 \\
\hline & 1 & 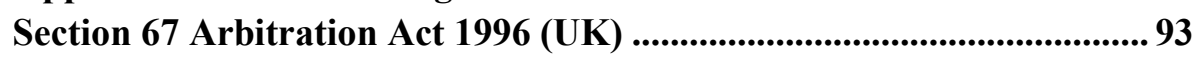 \\
\hline & 2 & 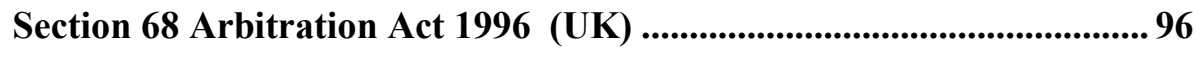 \\
\hline & 3 & 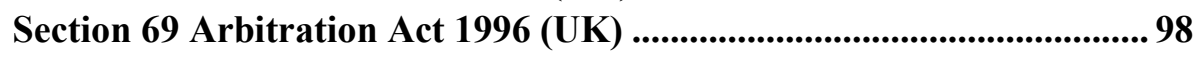 \\
\hline \multirow[t]{3}{*}{ D } & & 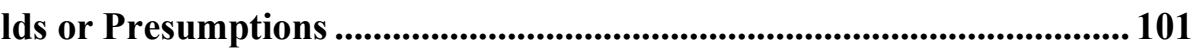 \\
\hline & 1 & 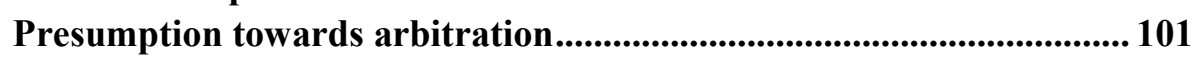 \\
\hline & 2 & Deference to findings of Tribunal ............................................................. 103 \\
\hline \multirow[t]{3}{*}{$\mathbf{E}$} & & 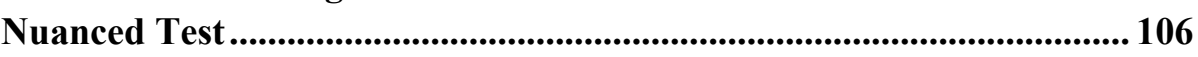 \\
\hline & 1 & 108 \\
\hline & 2 & 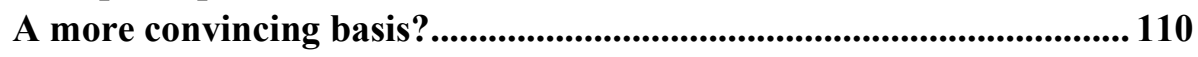 \\
\hline & & SION \\
\hline & & RAPHY \\
\hline
\end{tabular}




\section{Acknowledgement}

Much gratitude is owed to Dr Petra Butler and Professor Tony Angelo for their unwavering support and guidance over this period of study. Thanks also to my colleagues at MNZ for their indulgence, and last, but most definitely not least, to family and friends, especially Dan, for their tolerance and patience. 


\begin{abstract}
This paper examines the decision of the United Kingdom Supreme Court in Dallah Real Estate and Tourism Holding Company v The Minister of Religious Affairs, Government of Pakistan, a rare case where an English court refused enforcement of an international arbitral award under the United Nations Convention on the Recognition and Enforcement of Foreign Arbitral Awards (the New York Convention).

Although in Dallah the United Kingdom Supreme Court acknowledged the trend to limit reconsideration of the findings of arbitral tribunals in fact and in law, the Court considered it was bound to decide the question of validity de novo. Contrary to the tribunal, the Court held the arbitration agreement was not valid under the law to which it was subject and refused enforcement of the arbitral award.

This paper analyses how the English Supreme Court decided the legal issues before it. It concludes the English court could have reached the same decision on a more convincing basis. Even where the issue is initial consent, holding the court at the place of enforcement is always bound to decide a matter de novo neither serves the objectives of international commercial arbitration nor is necessary to promote the fundamental integrity of arbitral proceedings.
\end{abstract}

\title{
Word length
}

The text of this paper (excluding abstract, table of contents, footnotes and bibliography) comprises approximately 31,951 words.

\section{Subjects and Topics}

International Commercial Arbitration - Enforcement of Foreign Arbitral Awards - Role of Court at Place of Enforcement 


\section{Introduction}

This paper examines the decision of the United Kingdom Supreme Court in Dallah Real Estate and Tourism Holding Company $v$ The Minister of Religious Affairs, Government of Pakistan. ${ }^{1}$ Dallah is a rare case where an English court refused enforcement of a foreign arbitral award under the United Nations Convention on the Recognition and Enforcement of Foreign Arbitral Awards (the New York Convention). ${ }^{2}$

Arbitration represents a conscious rejection of national court systems and their control. Moreover, studies consistently demonstrate international commercial arbitration is the preferred mechanism for resolution of transnational disputes over litigation in national courts. ${ }^{3}$ Consequently, the question of the scope and extent of control by a national court on matters that have been the subject of consideration and determination by an arbitral tribunal is of more than theoretical interest. Identifying how a court may exercise control, and understanding why, has practical implications for the users of international commercial arbitration. Those practical implications go to the very choice of arbitration as an appropriate means of dispute resolution, the parties' choice of the arbitral seat and place where enforcement may be sought, as well as the efficacy of the framework for international arbitration as a whole in meeting its objectives. It is for these reasons the decision in Dallah is of "international importance."

The English court proceedings followed Dallah's attempt to enforce in England the award of the arbitral tribunal seated in Paris. The arbitration proceedings arose from an agreement signed on behalf of Dallah and the Awami Haj Trust, established by the Pakistani Minister of Religious Affairs, under which Dallah would provide housing for

\footnotetext{
${ }^{1}$ Dallah Real Estate and Tourism Holding Company $v$ The Minister of Religious Affairs, Government of Pakistan [2010] UKSC 46, [2011] 1 AC 763, (henceforth Dallah UKSC).

${ }^{2}$ United Nations Convention on the Recognition and Enforcement of Foreign Arbitral Awards 1958 (opened for signature on 21 December 1958, entered into force 7 June 1959). Until the decision in Dallah the only two reported cases where enforcement had been refused in England were Irvani v Irvani [2000] 1 Lloyd's Rep 412 and Kaniora v Guinness [2006] EWCA Civ 222, [2006] 1 Lloyd's Rep 701.

${ }^{3} 2013$ International Arbitration Survey Corporate choices in International Arbitration: Industry Perspective (School of International Arbitration at Queen Mary University of London) and previously, 2012 International Arbitration Survey Current and Preferred Practices in the Arbitral Process; 2010 International Arbitration Survey Choices in International Arbitration; 2008 International Arbitration Survey Corporate Attitudes and Practices: Recognition and Enforcement of Foreign Awards; 2006 International Arbitration Study: Corporate Attitudes and Practices. $<$ http://www.arbitrationonline.org/research/2013/>.

${ }^{4}$ Dallah UKSC above n 1 at [71] per Lord Collins.
} 
pilgrims, subject to a lease and associated financing. Enforcement was opposed by the Government of Pakistan on the basis it was not a party to the arbitration agreement.

One of the fundamental issues the Court had to decide was the role of the court at the place where enforcement was sought, when the validity of an arbitration agreement is challenged on grounds set out at Article V(1)(a) of the New York Convention.

The New York Convention has been ratified by 148 States, ${ }^{5}$ reflecting a broad range of the international community in geographical, legal-cultural and economic terms. ${ }^{6}$ The New York Convention defines the relationship between the courts and arbitration proceedings by a set of uniform rules. Those rules require national courts to give effect to foreign arbitration agreements, and to recognise and enforce foreign arbitral awards. Arbitral awards have presumptive validity, subject only to a limited - and exhaustive - list of exceptions specified at Article V of the New York Convention. Indeed, is the very ability for the State to exercise its coercive power in support of the arbitral process that helps makes arbitration the preferred mechanism for resolution of international commercial disputes.

In Dallah the United Kingdom Supreme Court expressly acknowledged the trend "both national and international to limit reconsideration of the findings of arbitral tribunals, both in fact and in law." Nonetheless the Supreme Court confirmed the task of the enforcement court was a rehearing rather than a review, holding an English court: ${ }^{8}$

...is entitled (and indeed bound) to revisit the question of the tribunal's decision on jurisdiction if the party resisting enforcement seeks to prove that there was no arbitration agreement binding upon it.

\footnotetext{
$\overline{5}$ The New York Convention, "New York Convention Countries" <www.newyorkconvention.org/newyork-convention-countries>.

${ }^{6}$ G Born International Commercial Arbitration (Kluwer Law International, Netherlands, 2009) at 99 fn 58 citing G Petrochilos Procedural law in International Arbitration (Oxford University Press, USA, 2004) at 16.

${ }^{7}$ Dallah UKSC above $\mathrm{n} 1$ at [101] per Lord Collins.

${ }^{8}$ Dallah UKSC above $\mathrm{n} 1$ at [104] per Lord Collins.
} 
Contrary to the tribunal, the Supreme Court (like the English High Court ${ }^{9}$ and Court of Appeal ${ }^{10}$ before it) held the arbitration agreement was not valid under the law to which it was subject, and refused enforcement of the arbitral award.

To reach that decision the Court had to form a view on the core submissions by Dallah namely, (1) the policy of the New York Convention gives primacy to the 'supervisory' court at the arbitral seat meaning only the supervisory court could undertake a substantive review, (2) an enforcement court was required to give deference to the findings of the arbitral tribunal, and (3) issue estoppel arose either by decision of the tribunal on its own jurisdiction or by the failure of the Government of Pakistan to challenge the award at the arbitral seat.

Only three months after the decision of the United Kingdom Supreme Court, the Paris Court of Appeal (being the court of the arbitral seat) upheld the decision of the tribunal, finding the agreement was valid under French law. ${ }^{11}$

While some commentators have broadly accepted the approach by the Supreme Court (or at least aspects of it) ${ }^{12}$ others have surmised the decision may have resulted from the English court viewing proceedings, which required the application of French law, through "English spectacles."13 Less equivocally, Gary Born has characterised Dallah as a "pathological" case,${ }^{14}$ commenting that "...the decision accords scant deference to the arbitral process and the considered conclusions of arbitral tribunals." $" 15$

\footnotetext{
${ }^{9}$ Dallah Real Estate and Tourism Holding Company $v$ The Minister of Religious Affairs, Government of Pakistan [2008] EWHC 1901, [2009] 1 All ER (Comm) 505 (henceforth Dallah HC).

${ }^{10}$ Dallah Real Estate and Tourism Holding Company $v$ The Minister of Religious Affairs, Government of Pakistan [2009] EWCA Civ 755, [2010] 1 All ER 592, (henceforth Dallah CA).

${ }^{11}$ Gouvernement du Pakistan v Societe Dallah Real Estate \& Tourism Holding Co, Cour d'appel, de Paris, Pôle 1 - Ch.1, n 09/28533 (February 17, 2011).

${ }^{12}$ Patrick Heneghan \& Jonathon Egerton-Peters "Dallah v Pakistan: Vive la différence?" (2011) 6 (3) Global Arbitration Rev. 25 at 26, Devika Khanna "Dallah: The Supreme Court's Positively Pro-Arbitration "No" to Enforcement" (2011) 28 J. of Int'l Arbitration 127, at 129-130.

${ }^{13}$ Nicholas Bouchardie, Paul Brumpton, Christophe von Krause, Christophe Seraglini and Robert Wheal "Insight: In Dallah, the Paris Court of Appeal and UK Supreme Court Reach Contrary Decisions Applying Same Law to Same Facts" (February 2011) White \& Case Newsletters <www.whitecase.com>.

${ }^{14}$ Gary Born "Dallah and the New York Convention" (7 April 2011) Kluwer Arbitration Blog $<$ www.kluwerarbitrationblog.com>.

${ }^{15}$ Gary Born "The Impact of Dallah" (10 February 2011) Kluwer Arbitration Blog $<$ www.kluwerarbitrationblog.com>.
} 
This paper analyses the issues in Dallah, the approach of the respective courts, and argues that Dallah should, at best, represent a high-water mark, for de novo review.

Part II sets out the context of the proceedings. It describes the autonomous nature of international commercial arbitration, canvassing its objectives and the development of the international legal framework. Part III then briefly describes the background to the proceedings, the decision of the arbitral tribunal and the legal issues decided under the New York Convention.

Part IV analyses how the Court decided an enforcement court was bound to decide by way of a rehearing. It analyses how the legal issues were framed, and demonstrates the Court approached the legal issues from a domestic rather than international framework. Further the Court appeared to conflate the question of the courts task and how it should fulfil that task. It concludes the justification for a mandatory rehearing when enforcement is opposed is not compelling.

Part V reviews how the Court decided the Government was not a party to the arbitration agreement, and how two Courts applying the same law to the same facts can reach different decisions. The Court's approach suggests there are some matters where the English courts prefer the policy of legal certainty in commercial transactions rather than finality of arbitral awards. In cases where there are competing principles Dallah may influence courts in other cases to strive for 'the right result'. Such an approach has the potential to undermine the finality and enforceability of arbitral awards as well as the goal of uniform approach to treatment of arbitral awards.

Part VI considers the effect of a Court being bound to conduct a rehearing whenever a party resists enforcement, identifying the pathological consequences that would result. The alternative options are reviewed, demonstrating it was not necessary to hold that an enforcement court is always bound to decide the question of validity de novo. It argues alternative approaches would better serve the objectives of the New York Convention. A more nuanced test to the role of enforcement courts when faced with a challenge to the validity of an arbitration agreement under Article V of the New York Convention can, and should, be developed.

This paper concludes holding that a court at the place of enforcement is always bound to decide a matter de novo neither serves the objectives of international commercial 
arbitration nor is necessary to promote the fundamental integrity of arbitral proceedings. Moreover, the English Supreme Court might have reached the same result on a more convincing basis. 


\section{Dallah in Context: The borders between courts and arbitration}

The relationship between courts and arbitral proceedings has always varied according to the prevailing political, historical and social contexts. ${ }^{16}$ From suspicion as to whether arbitration was even a legitimate means of dispute resolution capable of recognition or enforcement by national courts, recent developments see national court systems actively promoting their jurisdiction as "pro-arbitration" or "arbitration friendly." 17

The nature of arbitral proceedings and the nature of disputes more generally, ensure a continued role for national courts given the many borders they share with arbitration. The points where arbitral proceedings and national courts may find themselves meeting include prior to the start of arbitration (where one party seeks to instigate proceedings in national court where an arbitration agreement is claimed to exist), where an arbitral tribunal has been constituted, during arbitral proceedings and (as in Dallah) where enforcement of an arbitral award is sought.

In the modern context of the international framework provided by the New York Convention, and many 'pro arbitration' domestic regimes, Gary Born characterises "border skirmishes" between national courts and arbitral proceedings as largely constructive and a necessary part of making the hybrid regime effective. ${ }^{18}$ This reflects a view that the needs of modern arbitration practice will naturally evolve as courts and institutions react to new circumstances.

\footnotetext{
${ }^{16}$ See generally G Born International Commercial Arbitration (Kluwer Law International, Netherlands, 2009) at ch 1.

${ }^{17}$ For example, see speech of the Chief Justice of the Supreme Court of Victoria (Australia) M Warren AC, "Australia as a safe and neutral arbitration seat", speaking notes Australian Centre for International Commercial Arbitration's “The Australian Option" Chinese Tour, Shanghai and Beijing, People's Republic of China, 6-7 June $2012<\mathrm{http}: / /$ www.supremecourt.vic.gov.au/home/library/speech++ australia + as $+\mathrm{a}+\mathrm{safe}+$ and + neutral + arbitration + seat $>$. A relatively recent statement by the Canadian Supreme Court to the effect that it is not the judiciary's role to encourage arbitration as a dispute resolution method was met with concern that the "arbitration friendliness" of Canada would be diminished, a fact subsequently not borne out. Telling was the eagerness of the judiciary itself to confirm Canada as an arbitration friendly jurisdiction, see Seidel v. TELUS Communications Inc. [2011] 1 S.C.R. 531 and Marc Gold "Canadian Courts One Year after Seidel: Pro-Arbitration and Still Holding" (2 August 2012) Kluwerblog <http://kluwerarbitrationblog.com >.

${ }^{18}$ Gary Born keynote address at "Border Skirmishes: The Intersection between Litigation and International Commercial Arbitration" (21 October 2011) University of Missouri School of Law, Center for the Study of Dispute Resolution 2011 <mms://streaming.missouri.edu/public/law/csdr2011/keynote.wmv>.
} 
However the decision of the English court in Dallah is more than a "border skirmish" and represents a "border incursion." 19 To understand why, and to understand the basis of Dallah's submissions, it is helpful to revisit the function of a court in relation to arbitration. In particular, the policy considerations that underpin the relationship, how these have changed over time, and how the domestic and international legal framework specifically developed a limited role for national courts to meet the objectives of arbitration and the needs of the international business community.

\section{A The Nature of Arbitration}

Arbitration is the "process by which parties consensually submit a dispute to a nongovernmental decision maker, chosen by or for them, to render a binding resolution of the dispute in accordance with adjudicatory processes affording the parties an opportunity to be heard. ${ }^{20}$

Arbitration developed because of the demand from those who regard it as better meeting their needs and overcoming the limitations of existing public institutions. The limitations of national legal systems have remained remarkably consistent throughout the ages. Sources from Ancient Greece, medieval England, and 18th century America report overburdened judicial systems subject to delay and utilised at great expense. ${ }^{21}$ As Gary Born notes, the nature of commercial transactions between merchants in medieval England bears many of the hallmarks of modern international commerce and the "special jurisdictional and enforcement obstacles" they present. ${ }^{22}$

Litigation brings with it inefficiencies and uncertainty. The prospect of parallel proceedings in different courts claiming jurisdiction, inconsistent decisions and difficulties enforcing awards have remained constant. ${ }^{23}$ It is for these reasons Gary Born

\footnotetext{
${ }^{19}$ Born, above $\mathrm{n} 18$.

${ }^{20}$ Born International Commercial Arbitration, above n 16 at 217.

${ }^{21}$ Born International Commercial Arbitration, above n 16 at Ch 1.

${ }^{22}$ Born International Commercial Arbitration, above n 16 at 28. Born refers to III Blackstone's Commentaries on the Laws of England (1768) where Blackstone commented on the reason for use of arbitration by merchants in medieval England, saying: "The reason of their original institution seems to have been to do justice expeditiously among the variety of persons that resort from distant places to a fair or market; since it is probable that no inferior court might be able to serve its process, or execute its judgments, on both or perhaps either of the parties."

23 Born International Commercial Arbitration, above n 16 at 3, in respect of the feudal period see M Bloch, Feudal Society 359 (1961) cited in Born International Commercial Arbitration, above n 16 at 32, and for modern references see G Born International Commercial Arbitration above n 16 at 32-57.
} 
describes international arbitration as an 'autonomous' system "specifically designed to achieve a particular set of objectives which other branches of private international law fail satisfactorily to resolve." ${ }^{24}$ Some objectives of arbitration are largely the same whether domestic or international: enforceable agreements and awards, commercial competence and expertise of tribunal, finality of decision's, party autonomy and procedural flexibility, cost, speed, confidentiality or privacy of dispute resolution process, and the facilitation of amicable settlement. To the objectives specific to international commercial arbitration can be added neutrality and centralisation of the dispute resolution forum. ${ }^{25}$ Above all, the avoidance of litigation before national courts is fundamental: ${ }^{26}$

In short, while speed, informality, and economy have had some influence on the growth of international commercial arbitration, the essential force has been the desire of each party to avoid having its case determined in a foreign judicial forum.

However there are often qualifications on arbitration due to public policy of the State or local traditions. ${ }^{27}$ Arbitration may be private in many ways, but "[t]here is no private life which is not determined by a wider public life". ${ }^{28}$ A States arbitration laws reflect the balance of competing policy issues. These include the right of access to courts, freedom of contract, the importance of holding parties to their bargains, the finality of litigation, the interest in reducing duplication of effort and conserving judicial resources, discouraging dilatory tactics, costs of multiple proceedings, as well as (the somewhat amorphous) 'public policy' considerations.

Historically, approaches have differed from State to State. This reflects the legal and cultural distinctions between States whether arising from political or religious differences or from common law and civil law influences. ${ }^{29}$ Equally, the approach within a State's legal system might distinguish between domestic, international and foreign arbitrations though these conceptualisations escape easy description. For example, while English domestic law historically focused on the residence or nationality of parties to determine

\footnotetext{
${ }^{24}$ G Born International Commercial Arbitration above n 16 at 189.

${ }^{25}$ G Born International Commercial Arbitration (Kluwer Law International, Netherlands, 2009) at $71-90$.

${ }^{26}$ W. Laurence Craig "Some Trends \& Developments in the Laws and Practice of International Commercial Arbitration" (1995) 30 Tex. Int'l L.J 1 at 2.

${ }^{27}$ G Born International Commercial Arbitration above n 16 at 111.

${ }^{28}$ George Eliot (Mary Anne Evans Felix Holt, the Radical (1866).

${ }^{29}$ Thomas E Carbonneau, "The Exercise of Contract Freedom in the Making of Arbitration Agreements, (2003) 36 V and J. Trannat'l L, 1189 at 1206 cited in Julian Lew "Does National Court Involvement Undermine the International Arbitration Process” (2008-2009) 24 Am. U. Int'l Rev. 489 at 535.
} 
whether arbitration was domestic, French law looked to whether "international commercial interests" were implicated. American law represented something of a halfway house, including commercial matters that had a foreign element though otherwise excluding commercial contracts between citizens. ${ }^{30}$

Domestic laws further indicate differing views of the relationship between domestic laws and international arbitration: the law applicable to arbitration as opposed to the law applicable in arbitration. The two extremes have been described by one scholar as "the dogmatic territorialism of Francis Mann" and "Parisian Poetry." ${ }^{31}$ In the former no act can have any legal effect except as the result of a sanction given to it by a specific system of national law, while under the latter the authority operates outside any national legal order.

The fundamental characteristic of modern international commercial arbitration is the existence of a legal framework that strives to "unify the standards by which agreements to arbitrate are observed and arbitral awards are enforced in the signatory nations." ${ }^{23}$ This international legal framework seeks to achieve the objectives of international commercial arbitration by leaving only a limited role for national courts.

\section{B The International Legal Framework for Recognition and Enforcement}

A legal framework was needed to support the expansion of international trade in the early nineteenth century. The impetus for the development of modern international commercial arbitration was driven by the international business community and bolstered by support from the International Chamber of Commerce and increased lobbying by the legal profession. $^{33}$

\footnotetext{
${ }^{30}$ W. W Park "The Lex Loci Arbitri and International Commercial Arbitration" (1983) 32 ICLQ 21 at 43.

${ }^{31}$ Jan Paulsson "Arbitration in Three Dimensions" (text of inaugural lecture as Centennial Professor at the LSE delivered 24 November 2009) LSE Law, Society and Economy Working Papers 2/2010 at 2 $<$ www.lse.ac.uk/collections/law/wps/wps.hm>.

${ }^{32}$ Scherk v Alberto-Culver Co., 417 U.S. 506, 502 n.15 (U.S S.Ct.1974) cited G Born International Commercial Arbitration (Kluwer Law International, Netherlands, 2009) at 95.

${ }^{33}$ G Born International Commercial Arbitration above n 16 at 58-59. See also Julius Henry Cohen, "The Law of Commercial Arbitration and the New York Statute" (1921) Yale Law Journal 147 at 148 referring to Statements of the Committee on Law Reform which described the historical attitudes that relegated many arbitration agreements as nullities and unenforceable as "unintelligible" to the business man saying "the demands of international commerce dictate that this nation should not be behind others, either honesty
} 
By the nineteenth century, the use of multilateral conventions to regulate international arbitration proceedings had already occurred in the State to State context with the Montevideo Convention, the 1899 Pacific Settlement of Disputes and the 1907 Hague Convention on the Pacific Settlement of Disputes. ${ }^{34}$ Although those instruments may not have been wholly successful they paved the way for the 1923 Geneva Protocol on Arbitration Clauses in Commercial Matters, subsequently ratified by a relatively small, but commercially significant number of States. ${ }^{35}$

Although article 1 of the Geneva Protocol limited its application to arbitration agreements "between parties subject respectively to the jurisdiction of different contracting states" where it did apply, it required State Parties to recognise the validity of an agreement. ${ }^{36}$ In addition, article IV imposed an obligation on national courts to give effect to those agreements, ${ }^{37}$ and to enforce awards made within its territory in accordance with its national laws. ${ }^{38}$ The effect of making international arbitration agreements more enforceable than domestic agreements was "reflecting a deliberate policy of promoting the use of arbitration to resolve international commercial disputes." 39

The limited application of the Geneva Protocol 1923 to domestic arbitral awards was remedied with the Geneva Convention for the Execution of Foreign Arbitral Awards of

or in facilitation of contracts containing agreements for arbitration of disputes" reported in Proceedings of New York State Bar Association (1902) 43282.

${ }^{34} \mathrm{G}$ Born International Commercial Arbitration above n 16 at 58.

${ }^{35}$ Geneva Protocol on Arbitration Clauses in Commercial Matters 1923 (opened for signature 14 September 1923, entered into force 28 July 1924), (“Geneva Protocol”). Ratification included for example, the United Kingdom, Germany, France, Japan, India, and Brazil, see G Born International Commercial Arbitration above $\mathrm{n} 16$ at 59.

${ }^{36}$ Geneva Protocol, art. I.

${ }^{37}$ Geneva Protocol, art IV "The tribunals of the Contracting Parties, on being seized of a dispute regarding a contract made between persons to whom Article I applies and including an arbitration agreement whether referring to present or future differences which is valid by virtue of the said article and capable of being carried into effect, shall refer the parties on the application of either of them to the decision of the arbitrators."

${ }^{38}$ Geneva Protocol, art III.

${ }^{39}$ G Born International Commercial Arbitration above n 16 at 59 citing further E. Gaillard \& J. Savage (ed) Fouchard Gaillard Goldman on International Commercial Arbitration (Kluwer Law International 1999) at 242, A Redfern \& M Hunter (eds) Law and Practice of International Commercial Arbitration ( $4^{\text {th }}$ ed, Sweet and Maxwell, London 2004) at 10-21. 
1927. ${ }^{40}$ The 1927 Geneva Convention required State Parties to recognise and enforce foreign awards (those made in another Contracting State not just in the State's territory) and prohibited substantive judicial review of the merits. ${ }^{41}$

While the principles were commendable, its efficacy was flawed in the execution. The Geneva Convention 1927 imposed the burden of proof on an award creditor and required double exequatur - whereby the award creditor had to show both that the award was final in the arbitral seat and was not contrary to the public policy of the State where enforcement was sought. ${ }^{42}$

Both the Geneva Protocol and Geneva Convention cease to have effect between parties that have become bound to its successor, the New York Convention. Contrary to suggestions the Geneva Protocol played little role in development of the modern law, Born says although imperfect in its application, it played "a critical role." 43

The Protocol's internationally binding requirement of recognition on the validity of arbitration agreements and the formulae used in implementing that requirement, had a profound and decisive effect on the future of international arbitration law and in the language of the New York Convention, the UNCITRAL Model Law, and other leading legislation and international instruments in the field.

The New York Convention applies to the recognition and enforcement of arbitral awards made in the territory of a State other than the State where recognition and enforcement is sought, and to arbitral awards not considered "domestic" in the State where recognition and enforcement is sought - foreign awards. ${ }^{44}$ In addition to continuing to promote and encourage the recognition and enforcement of foreign awards, one of the main aims of

\footnotetext{
${ }^{40}$ Geneva Convention for the Execution of Foreign Arbitral Awards of 1927 (opened for signature 26 September 1927 entered into force 25 July 1929) (“Geneva Convention”).

${ }^{41}$ Geneva Convention arts I, II, III, IV.

${ }^{42}$ Geneva Convention, art (1)(e).

${ }^{43}$ G Born International Commercial Arbitration above n 16 at 62. Notwithstanding their shortcomings the Geneva Conventions were a necessary destination on the journey to develop a workable framework for the resolution of international disputes. One of the more significant roles performed by the Geneva Protocol and Geneva Convention was the fact they "inspired and paralleled national legislation and business initiatives to augment the legal regime governing international commercial arbitration agreements." $c f \mathrm{H}$. Gharavi "The International Effectiveness of the Annulment of An Arbitral Award "46 (2002) referred to at G Born International Commercial Arbitration above n 16 at 59 fn 336.

${ }^{44}$ New York Convention 1958, art I(1).
} 
the New York Convention was to eliminate double exequatur and shift the burden of proof: $^{45}$

The main [aims] [of the New York Convention] were, first of all, the elimination of the double exequatur...Under the 1927 Geneva [Convention], we always requested both. It is logical to require an exequatur only in the country where enforcement of the award is sought and not also in the country where the award was made, but no enforcement sought. Another element of the proposal was to restrict the ground for refusal or recognition and enforcement as much as possible and to switch the burden of proof of the existence of one or more of these grounds to the party against whom the enforcement was sought. This again stands to reason.

Largely as a result of these changes it is widely accepted the New York Convention creates a presumptive obligation to enforce arbitral agreements and arbitral awards, frequently referred to as a "pro enforcement approach" 46 or "pro enforcement bias." What this "pro enforcement" policy requires of national courts in practice sits at the core of proceedings in Dallah.

As noted earlier, the New York Convention requires national courts to give effect to arbitration agreements, and to recognise, and enforce arbitral awards. ${ }^{48}$ The inclusion of provisions dealing with arbitration agreements, not just arbitral awards, was a late adoption, ${ }^{49}$ but represented a major innovation that has made the Convention "the cornerstone of current commercial arbitration." ${ }^{50}$ The language of the Convention is mandatory requiring that States "shall" recognise arbitral awards as binding and refusal of recognition or enforcement is permitted "only if" the party proves that one of the

\footnotetext{
${ }^{45}$ P. Sanders, Enforcing Arbitral Awards under the New York Convention: Experience and Prospects, UN No. 92-1-133609-0, at 3 (1998) "cited G Born International Commercial Arbitration (Kluwer Law International, Netherlands, 2009) at 2714.

${ }^{46}$ The ICCA's Guide to Interpretation of the New York Convention, A Handbook for Judges (International Council for Commercial Arbitration, 2011), at Ch I.2, available at $<$ http://www.arbitrationicca.org/index.html >.

${ }^{47} \mathrm{G}$ Born International Commercial Arbitration above $\mathrm{n} 16$ at 2716, referring to Ministry of Defense of the Islamic republic of Iran v Gould Inc., 969 F.2d 764 ( $9^{\text {th }}$ Cir 1992) and Brostrom Tankers AB v Factorias Vulcano SA, XXXY.B. Comm. Arb 591, 596-97.

${ }^{48}$ New York Convention, articles, III, V.

${ }^{49}$ This followed a proposal from the Dutch delegation, see A. van den Berg The New York Convention of $1958(1981)$ at $12-13$.

${ }^{50}$ M Kerr "Concord and Conflict in International Arbitration" (1997) 13 Arb. Int'l 121 at 127, cited G Born International Commercial Arbitration above n 16 at 95 fn 558.
} 
exception's is met. Failure to comply or give effect to these provisions puts a State in breach of its obligations as a party to the Convention. ${ }^{51}$

The exceptions to the obligations imposed on courts are specified at article $\mathrm{V}$ of the New York Convention, and are exhaustive. As these sit at the heart of the proceedings between Dallah and the Government of Pakistan it is helpful to set article V (1) out in full: ${ }^{52}$

(1) recognition and enforcement of the award may be refused, at the request of the party against whom it is invoked, only if that party furnishes to the competent authority where the recognition and enforcement is sought, proof that:

(a) The parties to the agreement referred to in article II were, under the law applicable to them, under some incapacity, or the said agreement is not valid under the law to which the parties have subjected it or, failing any indication thereon, under the law of the country where the award was made; or

(b) The party against whom the award is invoked was not given proper notice of the appointment of the arbitrator or of the arbitration proceedings or was otherwise unable to present his case; or

(c) The award deals with a difference not contemplated by or not falling within the terms of the submission to arbitration, or it contains decisions on matters beyond the scope of the submission to arbitration, provided that, if the decisions on matters submitted to arbitration can be separated from those not so submitted, that part of the award which contains decisions on matters submitted to arbitration may be recognized and enforced; or

(d) The composition of the arbitral authority or the arbitral procedure was not in accordance with the agreement of the parties, or, failing such agreement,

\footnotetext{
${ }^{51}$ Vienna Convention on the Law of Treaties 1969 (opened for signature 23 May 1969, entered into force 27 January 1980) art 18, 26 ("Vienna Convention 1969"). See The ICCA's Guide to Interpretation of the New York Convention, A Handbook for Judges above n 46 at Ch V.1, referring also two cases in investment arbitration where failure to recognise the validity of arbitration agreement constituted a breach of a bilateral treaty Saipem SpA v Bangladesh, International Centre for Settlement of Investment Disputes (ICSID) case no. ARB/05/07 and Salini Construttori SpA $v$ Jordan, ICSID case no, ARB/02/13, at $<$ www.icisd.world.bank.org. $>$.

${ }^{52}$ New York Convention, article V.
} 
was not in accordance with the law of the country where the arbitration took place; or

(e) The award has not yet become binding on the parties, or has been set aside or suspended by a competent authority of the country in which, or under the law of which, that award was made.

Those exceptions go to the integrity of foreign arbitral proceedings, being matters "considered as serious defects in the arbitration and award." ${ }^{53}$ They introduce international standards that must be established by the party opposing enforcement, not standards to be determined by reference to national laws. ${ }^{54}$ The exclusions at article V(1) do not allow recognition or enforcement to be refused where the tribunal got the law wrong or provide for substantive review on the merits of a dispute. This reflects that parties to international disputes favour efficiency and finality over protected appeal rights. ${ }^{55}$ The New York Convention enables a national court to decide if one of the exceptions has been proven, but how courts should fulfil that function is not expressed. This was a fundamental question for the Court in Dallah.

\section{The Relationship between Courts and Tribunals in the International Framework}

Underpinning the question of the court's function and how it should fulfil it, is the nature of arbitration and the relationship between the court and the tribunal. Principles of party autonomy and freedom of contract tell only part of the story. While parties may enter the realm of arbitration through private means, its efficacy requires a simultaneous 'relinquishment' of the public power and control that might otherwise be exercised by national courts. ${ }^{56}$ Understanding when a national legal system and its institutions may relinquish or retain control of arbitration, even in an international context, is informed by the analysis of how courts have conceived of their role, and that of the arbitral tribunal.

\footnotetext{
${ }^{53}$ A van den Berg The New York Convention of 1958 (1981) at 265.

${ }^{54}$ This distinguishes article V(1) from article V(2) New York Convention which permits enforcement or recognition to be refused where the subject matter of the dispute is not capable by settlement by arbitration, or is contrary to public policy under the laws of the country where enforcement is sought (and can be raised by the courts on its own volition).

${ }^{55} 2013$ International Arbitration Survey, above n 3.

${ }^{56}$ Julian Lew QC, "Does National Court Involvement Undermine the International Arbitration Process." (2008-2009) 24 Am. U. Int’l Rev. 489 at 491.
} 


\section{The role of the tribunal}

The general role of the tribunal is relatively straightforward. Its primary role is to decide the issue submitted to arbitration, in accordance with the law and procedures agreed by the parties. ${ }^{57}$ This flows largely from the exercise of party autonomy, but as well as giving effect to the parties' intentions, reflects the adjudicative nature of the arbitrator's role.

General obligations are expressly incorporated into most national arbitration legislation and institutional rules, though these are not exhaustive of arbitrators' duties. There is also a distinction between personal obligations, that may give rise to a remedy against the arbitrator personally, ${ }^{58}$ and subject matter obligations (jurisdiction, procedure, substantive decision), that may give rise to a remedy against the agreement or award through proceedings for annulment, recognition or enforcement. Further, the obligations imposed on a tribunal in respect of those three subject matter functions is not necessarily the same.

The obligations on the tribunal in respect of the procedures it follows are relatively straightforward: Failure to follow the procedures agreed by the parties, including for composition of the tribunal, forms a basis for refusing recognition and enforcement under the New York Convention and for setting aside or annulling the award under most national laws and under the Model Law. ${ }^{59}$ In practice this will require factual consideration as non-compliance with mere formalities will not necessarily be fatal, and failure to object will be deemed a waiver.

\footnotetext{
57 These are not exhaustive. Other duties such as confidentiality will attach see generally G Born International Commercial Arbitration above n 16 at 1615-1639. For recent discussion of the nature of the arbitrator's relationship to the parties under English law see Jivraj v Hashwani [2011] UKSC 40.

${ }^{58} \mathrm{G}$ Born International Commercial Arbitration above n 16 at 1638, 1639.

${ }^{59}$ Art V(I) New York Convention, arts 34, 36 Model Law. In practice the obligation to follow procedures imposed by the national law at the seat of arbitration arguably provides arbitrators with some leeway before annulment would necessarily follow. However the general principle to be discerned is that arbitrators must correctly give effect to the procedure agreed by the parties. Gary Born notes that although annulment or non-recognition is sometimes referred to as a "remedy" against the arbitrator for breach of his/her obligations, this is (strictly speaking) incorrect $c f$ J. Lew, L. Mistelis \& S. Kroll, Comparative International Arbitration (Kluwer International, The Hague, 2003) at 12-35, E Gaillard \& J Savage (eds) Fouchard Gaillard Goldman on International Commercial Arbitration (Kluwer International, The Hague, 1999) at 1135. See G Born above n 16 at 1644, 1645.
} 
The substantive decision is a decision of the tribunal, and it is generally not subject to review of the merits or scrutiny of the courts. Arbitrators finding of fact are effectively immune from scrutiny by the courts and this includes not only primary facts but any secondary findings or inferences of a factual nature. ${ }^{60}$ Put another way, the tribunal is generally not required to be "correct" in its decision resolving the merits of any dispute. ${ }^{61}$ This can be described as jurisdiction to decide includes jurisdiction to decide wrongly, and recognises the public policy interest in giving effect to agreements validly concluded. ${ }^{62}$

Any decision of course assumes 'jurisdiction' on the part of the tribunal. As William Park notes, "labelling matters as 'jurisdictional' puts them into the realm where judges would normally expect to exercise some scrutiny depending on the circumstances of the case and the approach of the relevant legal system." ${ }^{63}$ Further, "every jurisdictional ruling by an arbitrator begs two further questions, one relating to timing and the other to finality." Finality presumes that the decision of a national court will have preclusive effect, but that is not always the case. ${ }^{64}$

As both Dallah, and the response to the decision illustrate, there is an inherent tension between the scrutiny a court might usually be expected to exercise, and that within a legal framework that represents a conscious and deliberate rejection of a national judicial system and its controls. Different concepts of what exactly a jurisdictional question is, and the fact that in any one case, a decision will require determination of the relevant facts and the application of those facts to the law, adds a layer of complexity to the issue.

\footnotetext{
${ }^{60}$ Geogas SA v Trammo Gas Ltd ("The Baleares") [1993] 1 Lloyd's Rep 215 at [228], per Lord Steyn.

${ }^{61}$ Cf Mexico v Cargill, Incorporated [2011] ONCA 622 infra at 82-85.

${ }^{62}$ Historically this conflicted with the perceived public policy against ousting of the court's jurisdiction. In the $18^{\text {th }}$ century Lord Campbell was a proponent of this latter approach. His dismissive attitude towards earlier decisions holding the contrary, was set out most famously in the case of Scott v Avery: Is there anything contrary to public policy in saying that the Company shall not be harassed by actions, the costs of which might be ruinous, but that any dispute that arises shall be referred to a domestic tribunal, which may speedily and economically determine the dispute?... I can see not the slightest ill consequence that can flow from such an agreement, and I see great advantage that may arise from it...Public Policy, therefore, seems to me to require that effect should be given to the contract. Scott v Avery (1856) 5. H.L. Cas. 811, 853. See also van den Berg "The New York Convention of 1958: An Overview" (2008) ICCA $<$ http://www.arbitration-icca.org/articles. $>$.

${ }^{63}$ William Park, "The Arbitrator's Jurisdiction to Determine Jurisdiction", in International Arbitration 2006: Back to Basics? (ICCA congress Series No. 13, Kluwer, The Hague, 2007) at 65.

${ }^{64}$ Park, above $\mathrm{n} 63$ at 4.
} 


\section{The function of the court}

Courts fulfil a public and constitutional function. However, in the context of arbitration, the primary function of a court, crudely put, is to keep out of the way. The limited role envisaged for courts in the international context is demonstrated by the Model Law. ${ }^{65}$ The Model Law is territorial in its scope, applying where the place (seat) or arbitration is in the territory of a State (although in the context of international arbitration the territorial principle takes on a detached application) and provides that no court may intervene other than in accordance with the provisions of that law. ${ }^{66}$ The Explanatory Note to the Model Law expressly refers to the trend of limiting court involvement in international commercial arbitration, saying: ${ }^{67}$

This seems justified in view of the fact that the parties to an arbitration agreement make a conscious decision to exclude court jurisdiction and, in particular in commercial cases, prefer expediency and finality to protracted battles in court.

Even where the Model Law has not been incorporated, as in England, domestic legal regimes considered "supportive" or "pro arbitration" share similar traits. ${ }^{68}$ This is usually characterised by the court limiting its role to ensuring arbitration is effective, by referring parties to arbitration when there is an agreement to arbitrate (including staying its own proceedings), providing support to the arbitral process (through procedural assistance such as securing the attendance of witness and appointment of arbitrators), and (with

\footnotetext{
${ }^{65}$ UNCITRAL Model Law on International Commercial Arbitration (As adopted by the United Nations Commission on International Trade Law on 21 June 1985, and as amended by the United Nations Commission on International Trade Law on 7 July 2006) ("Model Law").

${ }^{66}$ Art 6 Model Law.

${ }^{67}$ Explanatory Note by UNCITRAL Secretariat on the 1985 Model Law on International Commercial Arbitration as amended in 2006 (reproduced in UNCITRAL Yearbook, vol XVI - 1985, United Nations publication. Sales No E.87.V.4). As adopted by the United Nations Commission on International Trade Law on 21 June 1985 on 7 July 2005 UN doc A/40/17, annex I and A/61/17, annex I) available at $<$ http://www.uncitral.org/pdf/english/texts/arbitration/ml-arb/07-86998_Ebook.pdf.>.

${ }^{68}$ G Born International Commercial Arbitration above n 16 at $109-115 c f$ comments attributed to Lord Mustill (one of the Arbitrators in Dallah), describing the focus on commercial advantage that drove the legislative amendments of the Arbitration Act 1979 as "shallow" and "rotten." The advent of the 1979 Act was wholly attributable to a desire to protect and promote London as a seat of international arbitration: Lord Hacking “The Story of the Arbitration Act 1979" (2010) 76 Arbitration 125-129.
} 
varying degrees of success) to prevent proceedings that occur in breach of an arbitration agreement). ${ }^{69}$ When it becomes necessary, arbitration also needs national courts to provide legitimacy to arbitration agreements and awards through the process for recognition and enforcement. The limitations on courts in those contexts have been set out above. Most developed jurisdictions have broadly similar pro arbitration regimes. ${ }^{70}$

It is a noticeable feature of the shift towards 'pro arbitration' legislative regimes that national courts themselves have recognised and developed two principles fundamental to arbitration: First, the recognition that an arbitration agreement is a distinct agreement that can be separated from the underlying contract, ${ }^{71}$ and second, the competence of a tribunal to determine its own jurisdiction and to proceed or decline to proceed to hear a dispute. ${ }^{72}$ These are most recognisable as the principle of separability and the doctrine of competence-competence ("jurisdiction on jurisdiction") though their form is not quite the same in all jurisdictions. The two doctrines are separate but complementary. ${ }^{73}$ While the principle of separability is generally uniform in its application, the principle of competence-competence has been said to "possess a chameleon-like quality that changes colour according to the national and institutional background of its application."74

Both become relevant where there are objections to the jurisdiction of an arbitral tribunal. Objections to a tribunal's jurisdiction may frequently arise at the outset of proceedings, when the question of whether the court or tribunal should decide the existence of an agreement to arbitrate arises, after proceedings have commenced, or when enforcement is sought.

At the first stage, before arbitration has even commenced, some courts elect to undertake only a prima facie review, conserving judicial resources until the conclusion of arbitral

\footnotetext{
${ }^{69}$ Ust-Kamenogorsk Hydropower Plant JSC (Appellant) v AES Ust-Kamenogorsk Hydropower Plant LLP (Respondent) [2013] UKSC 35 cf West Tankers Inc v Allianz SpA [2009] 1 AC 1138.

${ }^{70} \mathrm{G}$ Born International Commercial Arbitration above n 16 at 115.

${ }^{71}$ For example, in England see Heyman v Darwins Ltd [1942] AC 346, 374 and Harbour Assurance Co (UK) Ltd v Kansa General International Insurance Co Ltd [1993] QB 488, the principle now expressed in s 7 Arbitration Act 1996 (UK), Amokura Kawharu "Arbitral Jurisdiction" (2008) 23 New Zealand Universities Law Review 238 at 242.

${ }^{72}$ Christopher Brown Ltd v Gennossenschaft Osterreichischer Waldbesitzer Holzwirtschaftsbetriebe [1954] 1 Q. B. $812-13$.

${ }^{73}$ The distinction between separability and competence-competence is made clear in the English Arbitration Act 1996 at s 7 and 30 see G Born International Commercial Arbitration above n 16 at 960.

${ }^{74}$ W.W Park, "The Arbitrator's Jurisdiction to Determine Jurisdiction", in International Arbitration 2006: Back to Basics? (ICCA congress Series No. 13, Kluwer, The Hague, 2007) at 4.
} 
proceedings,${ }^{75}$ while some elect to undertake a comprehensive assessment at the outset, protecting the parties from the risk of incurring costs of arbitration unnecessarily. ${ }^{76}$ For others, the approach may vary depending on whether the court seized of the matters is at the place of arbitration (and therefore may have later supervisory jurisdiction over proceedings) or if the claimed arbitration has a foreign seat. ${ }^{77}$

Even where the court is located at the seat of arbitration some national courts have mandatory rules restricting intervention, in arbitral proceedings once commenced, ${ }^{78}$ while other take a more flexible approach. ${ }^{79}$ The intersect requires a balance to be struck between the interests of efficiency and avoiding duplication of resource, or preventing obstruction to the arbitral process and preventing unnecessary proceedings.

Competence competence is not merely a procedural mechanism, enabling a tribunal to proceed in the face of an objection. The benefit of a court deferring consideration includes the conservation of judicial resources, and the benefit of considered conclusions. In cases where courts do re-visit decisions made by arbitrators, usually there must be something more than an error of law or fact for intervention. In this context, the courts and counsel will commonly refer to the concept of deference, indicating at the least a presumption in favour of arbitration or arbitral authority, and as will be discussed shortly, perhaps something more.

When proceedings come before a national court there may be a tension between the limited role for court involvement envisaged by the international arbitral process, and its inherent judicial nature. Is the function to ensure legally correct results, to provide only such safeguards as are necessary to ensure fundamental fairness or to intervene only when the integrity of the arbitral process or interests of third parties are implicated? ${ }^{80}$

\footnotetext{
${ }^{75}$ France, which delays until the review of the arbitral award see Park "The Arbitrator's Jurisdiction to Determine Jurisdiction", above n 74 at 43.

${ }^{76}$ See Park "The Arbitrator's Jurisdiction to Determine Jurisdiction", above n 74 at 43 .

${ }^{77}$ As in Switzerland ,see Park "The Arbitrator's Jurisdiction to Determine Jurisdiction", above n 74 at 48.

${ }^{78}$ As in France and Germany, see John J Barcelo III, "Who decides the Arbitrator's Jurisdiction? Separability and Competence-Competence in Transnational Perspective" (2003) 36 Vanderbilt Journal of Transnational Law 1115 at 1124.

${ }^{79}$ For example, the United States see Park "The Arbitrator's Jurisdiction to Determine Jurisdiction", above n 74 at 43 .

${ }^{80}$ W W Park "The Lex Loci Arbitri and International Commercial Arbitration" (1983) 32 International and Comparative Law Quarterly 21 at 21-22.
} 
Julian Lew QC draws the analogy of international commercial arbitration to a giant squid "stretching its tentacles down from the domain of international arbitration to the national legal systems to forage for legitimacy, support, recognition and effectiveness." ${ }^{81}$ Where courts fail to provide the right support at the right time and in the right place, Lew observes that "the giant squid of international arbitration might be forced into shallower waters, where it will inevitably find itself in peril." 82

However, as Dallah illustrates, there are divergent views about how that legitimacy, support, recognition and effectiveness should be affected. Although most domestic legal systems provide for some allocation of competence between arbitral tribunals and courts in the support and control of international commercial arbitration proceedings, there remains a varied approach to how and when that competence is exercised, and to the relevance or effect of a prior arbitral, or even court, decision. Those domestic legal systems themselves, sit within an international framework that seeks to promote uniformity but leaves ample room for states and national court to implement and apply its provisions.

A fairly detailed description of the events leading to the dispute in Dallah is necessary. As later sections show, the nature of the facts had a significant influence on what the English courts did, what they could have done, and arguably, what they should have done.

\footnotetext{
${ }^{81}$ Julian Lew QC, "Does National Court Involvement Undermine the International Arbitration Process." (2008-2009) 24 Am. U. Int'l Rev. 489 at 493.

${ }^{82}$ Julian Lew QC, "Does National Court Involvement Undermine the International Arbitration Process." (2008-2009) 24 Am. U. Int'l Rev. 489 at 537.
} 


\section{The Proceedings}

The dispute arose out of dealings between Dallah, the Religious Affairs Division of the Ministry of Religious Affairs, and the Awami Haj Trust, established by the Pakistani Minister of Religious Affairs. These centred on arrangements for Dallah to provide housing for pilgrims, subject to a lease and associated financing.

\section{A Background}

\section{The parties}

The Religious Affairs Division of the Ministry of Religious Affairs (MORA) is a Ministry of the Federal Government of Pakistan. ${ }^{83}$ MORA includes amongst its functions matters relating to the welfare and safety of pilgrims beyond Pakistan, and donations for religious purposes. ${ }^{84}$ Dallah Real Estate and Tourism Holding Company (Dallah) is a Saudi Arabian company, and the largest provider of services to Muslims who perform Hajj. ${ }^{85}$ Dallah and the Government of Pakistan had a pre-existing and longstanding commercial relationship. ${ }^{86}$

The establishment of the Awami Hajj Trust was approved in principle by the Pakistani Cabinet in December 1994. Before the Trust could come into effect it required an Ordinance promulgated by the President of Pakistan. A cabinet committee chaired by the Minister of Finance determined it should take corporate form with objectives related to the investment of savings from pilgrims for the purpose of performing Hajj. ${ }^{87}$

\section{Memorandum of Understanding}

On 15 February 1995 an approach was made by Dallah to the Government of Pakistan to provide housing on a long term lease with associated funding. ${ }^{88}$ This resulted in a

\footnotetext{
${ }^{83}$ Defined as such under The Rules of Business 1973, promulgated by under the Constitution of the Islamic Republic of Pakistan: Dallah HC above $\mathrm{n} 9$ at [8].

${ }^{84}$ Dallah $H C$ above $n 9$ at [8].

${ }^{85}$ Dallah $H C$ above $n 9$ at [8].

${ }^{86}$ Dallah UKSC above $\mathrm{n} 1$ at [3].

${ }^{87}$ The four objectives being (1) to mobilise savings from intended pilgrims (2) to invest such savings in Sharia approved modes of investment; (3) to meet the cost of performance of Hajj by members out of the balance of their accounts; and (iv) to take steps to facilitate the performance of Hajj by its members. See Dallah $H C$ above $n 9$ at [9].

${ }^{88}$ Dallah UKSC above $\mathrm{n} 1$ at [3].
} 
Memorandum of Understanding being entered into on 24 July 1995 between Dallah and the President of the Islamic Republic of Pakistan "through the Ministry of Religious Affairs." 89

Under the Memorandum of Understanding, Dallah would purchase land and build housing for pilgrims that would be taken under a 99 year lease by the Government, subject to Dallah arranging the necessary finance. ${ }^{90}$ Dallah was to submit both the terms and conditions of the proposed lease and the plans for housing to the Government of Pakistan for approval. ${ }^{91}$ The finance was to be "secured by the borrower designated by the Government of Pakistan under the Sovereign Guarantee of The Government of Pakistan.",92

\section{Establishment of the Awami Hajj Trust}

The Ordinance establishing the Awami Hajj Trust was promulgated on 31 January $1996 .^{93}$ The Ordinance provided for a number of matters including the appointment of the Minister of Religious Affairs (MORA) as Chairman of the board and the Secretary of the Religious Affairs Division of the Ministry to be a member of the board (if not appointed managing trustee) and to act as its Secretary. ${ }^{94}$

Article 3(2) of the Ordinance provided that the Trust was established as a body corporate "having perpetual succession and a common seal with power to acquire, hold and dispose of property, and may by its name, sue and be sued." However the Federal Government would determine where regional offices may be established ${ }^{95}$ and the board was required to obtain prior approval from the federal government before making rules "for carrying out the purpose of the Ordinance." 96

MORA formally notified the Trusts' creation on 14 February $1996 .^{97}$ On 29 February 1996, Dallah wrote to MORA with a revised proposal including options for the legal

\footnotetext{
${ }^{89}$ Dallah $H C$ above $\mathrm{n} 9$ at [11] and Annex 1.

${ }^{90}$ Clause 3, Memorandum of Understanding see Dallah $H C$ above $\mathrm{n} 9$ at [11] and Annex 1.

${ }^{91}$ Clause 4 \& 5 Memorandum of Understanding see Dallah $H C$ above $n 9$ at [11].

${ }^{92}$ Clause 5, Memorandum of Understanding Dallah HC above $\mathrm{n} 8$ at at Annex 1.

${ }^{93}$ Ordinance, No. VII of 1996 to provide for the establishment of the Awami Hajj Trust pursuant to Article 89(1) Constitution of the Islamic Republic of Pakistan.

${ }^{94}$ Article 5 Awami Hajj Trust Ordinance, No. VII of 1996.

${ }^{95}$ Article 3(3) Awami Hajj Trust Ordinance, No. VII of 1996.

${ }^{96}$ Article 12 Awami Hajj Trust Ordinance, No. VII of 1996.

${ }^{97}$ Dallah $H C$ above $\mathrm{n} 9$ at [15].
} 
structure taking account the involvement of both MORA, and the Trust ${ }^{98}$ At a subsequent Board of Trustees meeting on 30 July 1996 there was agreement to Dallah's proposal that it raise a loan of US\$100 million for the Trust. The Government of Pakistan was also to counter-guarantee the guarantee that was to be given by the Trust. ${ }^{99}$

Under Art. 89(2) of the Constitution of Pakistan, an Ordinance had to be laid before Parliament within 4 months, or renewed, or it would lapse. The Ordinance establishing the Awami Hajj Trust was not laid before Parliament but was renewed on 2 May 1996 and 12 August 1996 respectively. ${ }^{100}$

\section{Agreement between Dallah and the Awami Hajj Trust}

Dallah and the Government of Pakistan continued to engage in negotiations and an Agreement between Dallah and the Trust was subsequently entered into on 10 September 1996. The Agreement was signed by the Minister of Religious Affairs in his capacity as Chairman of the Trust Board.

Under the Agreement, Dallah would construct and complete housing for Pakistani Pilgrims performing Hajj and Umra, ${ }^{101}$ while the Trust agreed to pay a lump sum advance lease payment of US\$100 million. ${ }^{102}$ The payment was subject to Dallah arranging that finance against a guarantee of the Government of Pakistan, and the Trust approving specifications for the proposed housing within 90 days of execution of the Agreement. $^{103}$

The Agreement provided for arbitration, the arbitration clause, saying in full: ${ }^{104}$

Any dispute or difference of any kind whatsoever between the Trust and Dallah arising out of or in connection with this Agreement shall be settled by arbitration

\footnotetext{
${ }^{98}$ Dallah UKSC above n 1 at [6].

${ }^{99}$ Dallah $H C$ above $n 9$ at [16].

${ }^{100}$ As Ordinance LXXXI of 1996 and Ordinance XLIX of 1996.

${ }^{101}$ Clause 1 Agreement between Dallah and the Awami Hajj Trust dated 10 September 1996, Dallah HC above $\mathrm{n} 9$ at Annex 3 .

${ }^{102}$ Clause 2 Agreement between Dallah and the Awami Hajj Trust dated 10 September 1996, Dallah HC above $\mathrm{n} 9$ at Annex 3.

${ }^{103}$ Clause 4 Agreement between Dallah and the Awami Hajj Trust dated 10 September 1996, Dallah HC above $\mathrm{n} 9$ at Annex 3 .

${ }^{104}$ Clause 23 Agreement between Dallah and the Awami Hajj Trust dated 10 September 1996, Dallah HC above $n 9$ at Annex 3.
} 
held under the Rules of Conciliation and Arbitration of the International Chamber of Commerce, Paris by three arbitrators appointed under such Rules.

The Trust would not claim, and waived, immunity, ${ }^{105}$ and the agreement provided for the rights or obligations of the Trust to be transferred or assigned to the Government of Pakistan without the prior consent of Dallah. ${ }^{106}$

\section{Performance}

After the agreement was signed, civil servants from the Ministry of Religious Affairs, who had no other connection with the Trust, twice wrote to Dallah regarding different matters related to the Trust. ${ }^{107}$ On 26 September 1996 correspondence relating to the appointment of the Trustee Bank was sent, and on 4 November 1996 MORA requested Dallah send to it the "proposed rupee based savings scheme for Hajj finalised so far."108

By midnight of 11 December 1996 the Ordinance establishing the Trust had been in effect for 4 months without being laid before Parliament. It was not renewed and no new Ordinance was promulgated.

Following a change of Government in Pakistan on 6 November 1996, the relationship between Dallah and the Government deteriorated. On 19 January 1997, Mr Mufti wrote to Dallah, advising that the Agreement was no longer effective in law due to Dallah's failure to submit the plans for approval, or arrange the requisite financing facility. The letter was on Ministry of Religious Affairs' letterhead, signed as "Secretary", and in the header made reference to the agreement of 10 September $1996 .{ }^{109}$

\section{B Proceedings before the National Courts of Pakistan and Reference to Arbitration}

On 20 January 1997 the Trust (through Mr Mufti who swore his affidavit in his capacity as Secretary Board of Trustee of the Trust), ${ }^{110}$ attempted to bring proceedings against

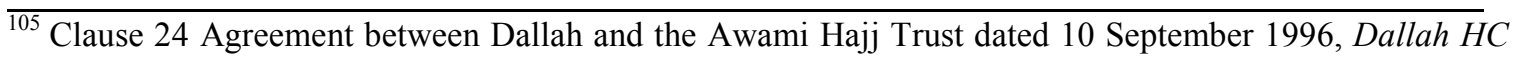
above $\mathrm{n} 9$ at Annex 3 .

${ }^{106}$ Clause 27 Agreement between Dallah and the Awami Hajj Trust dated 10 September 1996, Dallah HC above $\mathrm{n} 9$ at Annex 3.

${ }^{107}$ On 26 September 1996 and 4 November 1996 respectively.

${ }^{108}$ Dallah HC above $\mathrm{n} 9$ at [13].

${ }^{109}$ Dallah $H C$ above $n 9$ at [26].

${ }^{110}$ Dallah $H C$ above $n 9$ at [27].
} 
Dallah before the courts in Pakistan. The Trust sought a declaration that Dallah had repudiated the agreement and an order restraining it from making any claim under the agreement.

Dallah sought a stay of proceedings pending arbitration, which were opposed by the Trust, with Mr Mufti filing two further "counter affidavits. ${ }^{111}$ However, as the Ordinance establishing the Trust had not been renewed since 12 August 1996, and had not been laid before Parliament within the 4 months period required under the Constitution of Pakistan, it had lapsed. This meant the Trust no longer existed as a legal entity. ${ }^{112}$ Consequently, on 21 February 1998 the Court of the Senior Civil Judge, Islamabad held the claim could not proceed in the Trust's name. ${ }^{113}$

Dallah subsequently initiated arbitral proceedings against the Government of Pakistan, nominating Lord Mustill as its arbitrator: In its Points of Claim dated 19 May 1998 the Government of Pakistan was named as respondent. Dallah asserted (in reference to clause 23 of the main Agreement) "the respondent was at all material times a party to the Agreement and to the Arbitration Agreement" ${ }^{114}$ and specified: ${ }^{115}$

On 19.01.97 the Secretary, Ministry of Religious Affairs of the Respondent [i.e. the MORA], acting on behalf of itself as principal and on behalf of the Trust, purported to repudiate the Agreement....

The letter of 19.01.97 amounted to an unlawful repudiation of the Agreement and evidenced an intention on the part of the Respondent [ie the MORA] not to be bound by its terms. The Respondent continues to refuse to implement the Agreement. Accordingly the Claimant has accepted the Respondent's repudiation.

Then, a further series of thwarted court proceedings in the national courts of Pakistan followed.

$\overline{{ }^{111} \text { Dallah } H C \text { above } \mathrm{n} 9 \text { at [29] the pleadings also contained a verification of truth signed by Mr. Mufti as }}$ plaintiff.

${ }^{112}$ This was also the view of the experts on Pakistan law before Aikens J in the High Court. Although Aikens $\mathrm{J}$ expressed some scepticism at this conclusion, it was a matter of foreign law, and essentially an agreed fact he felt bound to accept it, Dallah $H C$ above n 9 at [18] fn 5.

${ }^{113}$ Dallah $H C$ above $n 9$ at [30].

${ }^{114}$ At para 18 and 19 Points of Claim Dallah $H C$ above $n 9$ at [31].

115 At para 23 of its Points of Claim Dallah $H C$ above $n 9$ at [31]. 
First, on 2 June 1998 another claim was filed in the Court of the Senior Civil Judge, Islamabad, by the "Islamic Republic of Pakistan through the Secretary, Ministry Religious Affairs" against Dallah on the same grounds as the civil claim initially made by the Trust. The claim was made on the basis that although the Trust stood repealed the cause of action had "accrued" to the Government. ${ }^{116}$

Pending the hearing, an interim order preventing Dallah from claiming a contractual relationship with Government of Pakistan under the Agreement was made. When the Government of Pakistan was notified by the International Chamber of Commerce (ICC) of Dallah's request for arbitration on 5 June 1998, the Government provided a copy of the order to the ICC in support of its assertion that the arbitration proceedings could not proceed while the matter was before the court. ${ }^{117}$

Dallah sought to stay these proceedings on the basis that MORA was a party to, and subject to, the arbitration clause of the Agreement. MORA did not directly deny that it was a party to the Agreement or arbitration clause, rather it sought to defeat the argument by claiming that no effective Agreement had come into effect due to the failure of Dallah to comply with the 'pre conditions'. ${ }^{118}$ After its unsuccessful application for a stay, ${ }^{119}$ the subsequent appeal by Dallah to the District Court became null after MORA sought to withdraw its claim due to 'a formal defect'. Withdrawal of the suits and disposal of the appeal occurred on 14 January 1999.

Subsequent applications by the Government of Pakistan under the Arbitration Act 1940 (Pakistan) seeking various declarations that the Government of Pakistan was not a party to the arbitration agreement were dismissed on Dallah's argument that the Government had no standing to bring a claim under the Arbitration Act 1940, while simultaneously

\footnotetext{
${ }^{116}$ Para 15 of the Government's claim said "That the cause of action accrued to the plaintiff against the defendant at Islamabad firstly when the defendant entered into the Agreement and thereafter when it defaulted in fulfilling the pre-conditions of the Agreement and the same was repudiated and finally in January 1997 when it refused to treat the Agreement as repudiated." Dallah HC above n 9 at [34].

${ }^{117}$ The Government relied on sections 34 and 35 of the Arbitration Act 1940 (Pakistan) which essentially provided that unless a stay was granted, a reference to arbitration could not proceed after legal proceedings had been commenced. Dallah HC above $\mathrm{n} 9$ at [33].

${ }^{118}$ Dallah $H C$ above $\mathrm{n} 9$ at [36].

${ }^{119}$ The application was dismissed on a variety of grounds including (1) the Arbitration Act 1940 did not apply to foreign arbitrations (2) In any event a stay could only occur on submission of both parties (3) No evidence was produced by Dallah to show Trust had transferred its rights and obligations (4) the Government of Pakistan was not a signatory to the Agreement and MORA was not a juristic person: see Dallah $H C$ above $n 9$ at [37].
} 
claiming it was a not a party and had no relationship with the Trust. Two subsequent attempts by the Government to file revised petitions also failed on the same grounds. In the Lahore High Court the presiding Judge commented on the status of the Government of Pakistan in relation to the agreement, holding: ${ }^{120}$

I therefore do find that the learned judge has very correctly found that the petitioner GoP is neither a party to the said agreement nor it claims under any of the parties to the same. This being so the petitioner cannot be proceeded against under the said arbitration agreement which forms part of the said agreement dated 10.0.1996.

The arbitration under the ICC continued notwithstanding Dallah's appeal to the Supreme Court in Pakistan, ${ }^{121}$ and the refusal of the Government of Pakistan to participate or sign the terms of reference agreed by the arbitrators and Dallah on 26 March 1999. On 17 April the ICC approved the terms of reference. Paris, France was the seat of arbitration.

\section{Proceedings before the Arbitral Tribunal}

The Arbitral Tribunal consisted of 3 highly respected arbitrators. Lord Mustill had been appointed on behalf of Dallah, and in accordance with its rules, the ICC appointed Justice Dr Nassim Hasan Shah as the Government's arbitrator and Dr Ghaleb Mahmassani as Chair.

In respect of jurisdiction, which the Tribunal dealt with first, the question the Tribunal considered it had to answer was: ${ }^{122}$

Does an agreement to arbitrate under the ICC rules exist between the Claimant (i.e. Dallah) and the Defendant (i.e. the Government of Pakistan) and does the arbitral tribunal have jurisdiction in respect to the Defendant over the claims submitted by the Claimant in the present case?

Only Dallah was represented at the oral hearings on 17 September 1999 and 27 March 2000, although the Government of Pakistan submitted written observations on 11 September 1999 on a without prejudice basis. A further memorial was provided by the

\footnotetext{
${ }^{120}$ Dallah $H C$ above $n 9$ at [43].

${ }^{121}$ The appeal included the question of the effect of Article 264 Constitution of Pakistan when an Ordinance lapsed. There is no record of the appeal proceeding.

${ }^{122}$ Dallah $H C$ above $n 9$ at [43].
} 
Government on 17 November 1999 in response to a request for assistance from the Tribunal, also on a without prejudice basis. ${ }^{123}$

Before the tribunal Dallah and the Government of Pakistan argued respectively, for the application of Saudi Arabian and Pakistani law on the basis that these were the systems of law with which the contract had the closest connection. ${ }^{124}$ However the legal test adopted by the Tribunal was determined by "reference to those transnational general principles and usages reflecting the fundamental requirements of justice in international trade and the concept of good faith in business." ${ }^{25}$ Although Lord Mustill and Dr Justice Shah expressed doubts about the notion of a "transnational procedural law independent of all nations" ${ }^{126}$ they agreed on the test to be applied: ${ }^{127}$

Arbitral as well as judicial case-law has widely recognised that, in international arbitration, the effects of the arbitration clause may extend to parties that did not actually sign the main contract but were directly involved in the negotiation and performance of such contract, such involvement raising the presumption that the common intention of all parties was that the non-signatory party would be a true party to such contract and would be bound by the arbitration agreement.

The reference to "common intention" indicates the Tribunal was applying the test set out by the French Cour de Cassation in Dalico. ${ }^{128}$ For the purpose of determining whether a valid arbitration agreement exists, Dalico looks to the intention of the parties rather than the law of the contract, the procedural law or other conflict of laws analysis. ${ }^{129}$

\footnotetext{
${ }^{123}$ Dallah $H C$ above $n 9$ at [47].

${ }^{124}$ Dallah $C A$ above n 10 at [24]. The decision and reasoning of the Tribunal has been discerned from references made within the decisions, primarily that of the High Court and Supreme Court.

${ }^{125}$ First Partial Award (FPA), Section III, para 4 (bis) page 20, referred to in Dallah HC above n 9 at [49].

${ }^{126}$ FPA, Section III, para 4 (bis) page 20 referred to in Dallah $H C$ above $n 9$ at [49] fn 14. The tribunal decided it was not necessary to determine the law applicable to the contract.

${ }^{127}$ FPA Section III, Para 6, Page 26, referred to in Dallah HC above n 9 at [49].

${ }^{128}$ Municipalite de Khoms El Mergeb v Soc Dalico, 20 December 1993, 1994 Rev Arb 116 (Cour de Cassation).

129 Municipalité de Khoms El Mergeb v. Société Dalico, December 20, 1993, Case no. 91-16828): “by virtue of a substantive rule of international arbitration, the arbitration agreement is legally independent of the main contract containing or referring to it, and the existence and effectiveness of the arbitration agreement are to be assessed, subject to the mandatory rules of French law and international public policy, on the basis of the parties' common intention, there being no need to refer to any national law." See Dallah UKSC above $\mathrm{n} 1$ at [114].
} 
The Tribunal reviewed the dealings related to the project in their entirety. Relevant was the structure of the Trust and the control the Government exerted over it as well as the guarantee to be provided by the Government, and the unilateral right of the Trust to assign its rights and obligations to the Government without prior consent.

In addition, the active involvement of the government officials in performance of the agreement was noted, alongside the failure of the Government to renew the Ordinance: ${ }^{130}$

The Trust, in spite of its distinct legal personality in theory, appears thus in fact and in conduct to have been considered - and to have acted - as a part and a division of the Defendant to which it is fully assimilated, a temporary instrument that has been created by a political decision of the Defendant for specific activities which the Defendant wanted to perform, and which was cancelled also by a political decision of the Defendant. Therefore, the Trust appears as having been no more than the alter ego of the Defendant which appears, in substance, as the real party in interest, and therefore as a proper party to the Agreement and to the Arbitration with the Claimant.

The Tribunal was influenced by the exchange of correspondence from Ministry officials and in particular the letter of termination which the arbitrators considered 'significant' because it confirmed in the clearest way possible, that the Government regarded the Agreement with Dallah "its own". ${ }^{131}$ In this respect, the Tribunal clearly regarded the reference to 'Secretary' in the signing of the correspondence as being in the capacity as Secretary of MORA, with the consequence: ${ }^{132}$

the signatory of the letter engages and binds the Government, as he has continued to bind it during the whole previous period where the Trust was in existence.

In addition, the proceedings brought by the Government on 2 June 1998 and the letter to the ICC of 5 June 1998 were considered relevant. The former was viewed as evidence the Government considered "that it was a party to such Agreement and that it could accept repudiation of the Agreement." ${ }^{133}$ The latter was relevant insofar as the Government asserted that arbitration could not proceed on the bass of the existence of

\footnotetext{
${ }^{130}$ FPA Section III, Para 12-1, referred Dallah UKSC above n 1 at [37].

${ }^{131}$ FPA Section III, Para 11-1, referred Dallah UKSC above n 1 at [56].

${ }^{132}$ FPA Section III, Para 11-1, referred Dallah UKSC above $\mathrm{n} 1$ at [56].

${ }^{133}$ FPA Section III, Para 11-2, referred Dallah UKSC above n 1 at [62].
} 
proceedings to which it was a party, and did not assert it was not a party to the agreement. $^{134}$

In holding that the Government was a party the Tribunal said: ${ }^{135}$

Certainly, many of the above mentioned factual elements, if isolated and taken in a fragmented way, may not be construed as sufficiently conclusive for the purpose of this section.

However, Dr Mahmassani believes that when all the relevant factual elements are looked into globally as a while, such elements constitute a comprehensive set of evidence that may be relied upon to conclude that the Defendant is a true party to the Agreement with the Claimant and therefore a proper party to the dispute that has arisen with the Claimant under the present arbitration proceedings.

Whilst joining in this conclusion Dr Shah and Lord Mustill note that they do so with some hesitation, considering that the case lies very close to the line.

Dr Mahmassani further considered the requirements of good faith and morality should operate to bind the Government of Pakistan. In contrast Justice Shah and Lord Mustill did not consider good faith could, absent other grounds, operate to make a non-signatory a party to an agreement. ${ }^{136}$ However, all the arbitrators agreed the result accorded with the "general justice of the case". ${ }^{137}$ The FPA recorded that Dr Shah and Lord Mustill were reassured "the more so given the background of the Memorandum of Understanding in which the participation of the State was not in doubt."

The tribunal made a first partial award on the question of jurisdiction on 26 June 2011. A second partial award on the merits (19 January 2004) was followed by a final award (23 June 2006) in Dallah's favour for breach of contract awarding US\$18,907,603 in damages as well as costs and expenses.

\footnotetext{
${ }^{134}$ First Partial Award (FPA), Section III, para11.2, referred to in Dallah $H C$ above $\mathrm{n} 9$ at [124].

${ }^{135}$ FPA Section III, para11.2 referred to in Dallah HC above $\mathrm{n} 9$ at [50].

${ }^{136}$ FPA Section III, para 14, page 35 referred to in Dallah $H C$ above $n 9$ at [51].

${ }^{137}$ FPA Section III, para114, page 35 referred to in Dallah HC above $\mathrm{n} 9$ at [51].

${ }^{138}$ Jan Kleinheisterkamp "Lord Mustill and the Courts of Tennis - Dallah v Pakistan, in England, France and Utopia” (2012) Modern Law Review 75 (4) 606 - 654 at 653, citing ICC Case No 9987, Partial Award on Jurisdiction of 26 June 2011 International Journal of Arab Arbitration [2010/2] 337 at 365-366.
} 


\section{Proceedings under the New York Convention}

Following some procedural hiccups, ${ }^{139}$ the English High Court granted Dallah permission to enforce the Final Award in England on 9 October 2006.

The order provided for the Government of Pakistan to apply to set the order aside and, unsurprisingly given the history in the matter, enforcement proceedings were resisted. Initially this was both on the basis that the Government was immune to enforcement as a State entity and that the Government of Pakistan was not a party to the arbitration agreement. The Government reserved its position on state immunity, but did not argue it before the English courts.

The ground on which the Government of Pakistan opposed recognition was under section 103(2) (b) of the Arbitration Act 1996 (UK). Section 103(2) (b) of the English statute reflects the grounds specified at Article V (1) (a) of the New York Convention:

...that the arbitration agreement was not valid under the law to which the parties subjected it, or failing any indication thereon, under the law of the country where the award was made.

\section{The legal issues}

The fundamental questions for the enforcement court was whether the Government of Pakistan was a party to the arbitration agreement with Dallah, and by what process should it determine that question - if at all?

As to the nature of the task to be undertaken by the court when enforcement proceedings were opposed under section 103(2) (b) Arbitration Act 1996, in the High Court, Aikens J characterised the question thus: ${ }^{140}$

\footnotetext{
${ }^{139}$ The original order granted by Gloster J on 12 July 1996 had a defect in form as it failed to properly set out the period that the State entity could apply to set aside the order in accordance with section 12(2) of the State Immunity Act 1978 (UK). An amended order was subsequently granted by Christopher Clarke J on 9 October 2006, and following application from Government of Pakistan the time to file any opposition to enforcement was extended by consent for 6 weeks while advice from French lawyers was obtained. See Dallah $H C$ above $n 9$ at [54].

${ }^{140}$ Dallah $H C$ above $n 9$ at [65].
} 
Is it a full hearing of all the relevant evidence, as Mr. Landau submits or, at least in this case is it more in the nature of a review of the decision of the arbitrators on the issue of jurisdiction as Miss Helibron argues?

The four key arguments before the English courts can be summarised briefly.

1. Whether the policy of the New York Convention gives primacy to the 'supervisory' court at the arbitral seat meaning only the supervisory court could undertake a substantive review.

Essentially Dallah submitted that as a matter of policy the New York Convention accords primacy to the supervisory courts, and consequently the supervisory court was the only court with jurisdiction for a wholesale rehearing, Article V.1 of the New York Convention otherwise "contemplating a review within a narrow compass."

Dallah identified a number of pragmatic reasons why the distinction between the primary and secondary jurisdiction was appropriate. This included legal certainty, as the court at the arbitral seat would be better placed to decide any question of law, and it would prevent the risk of different outcomes if enforcement was opposed in many different jurisdictions. ${ }^{142}$ In contrast, the Government of Pakistan argued that "when the issue is initial consent to arbitration, the Court must determine for itself whether or not the objecting party actually consented." 143

2. Whether an enforcement Court was required to give deference to the findings of the arbitral tribunal.

Although acknowledging that the Government bore the burden of proof (which it said it could seek to discharge as it saw fit) the Government submitted that while the Court

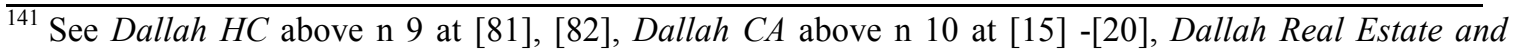
Tourism Holding Company $v$ The Minister of Religious Affairs, Government of Pakistan [2010] UKSC 46 at [20].

${ }^{142}$ Dallah $C A$ above n 10 at [19] per Lord Justice Moore Bick.

${ }^{143}$ Dallah UKSC above n 1 [31]. Although proceedings for enforcement were brought by Dallah and opposed by the Government of Pakistan on the basis that it was not a party to the arbitration agreement the Government of Pakistan's submissions are conspicuously absent from the judgments, which focus almost exclusively on the submissions made on behalf of Dallah. The relevance of this is discussed further below at 78 .
} 
"may have regard to the reasoning and findings of the alleged arbitral tribunal, if they are helpful" it was "neither bound nor restricted by them."144

Conversely, Dallah argued a court should only 'review' the tribunal's decision as to whether there was a valid arbitration agreement, and should not conduct a re-hearing. ${ }^{145}$ The court should 'afford deference' to the tribunal, and decisions of the tribunal should be given 'strong evidential effect', and upheld where the tribunal's conclusions could be regarded as plausible or 'reasonably supportable.,"

3. Whether issue estoppel arose either by decision of the Tribunal on its own jurisdiction or by the failure of the GoP to challenge the award at the arbitral seat.

Dallah submitted the Government should be estopped from arguing it was not a party to the arbitration agreement. This was based on six points but essentially relied on the argument that the decision on the merits was made by a competent tribunal, which was final and conclusive, and this should prevent the Government from raising the same points again. $^{147}$

The basis for estoppel also appeared to rest in part on the status of the award under French law, given the failure of the Government, at least initially, to have taken steps in France to challenge the award. The initial basis of the Government's extension to time to oppose enforcement had been for the purpose of deciding whether to challenge the awards in France. The Government solicitor (somewhat curiously) made a statement to the Court saying: ${ }^{148}$

A successful challenge to the award(s) in France would have provided the [GOP] with a ground to resist enforcement in England on the basis of s. 103(2) (f) of the Arbitration Act 1996. This process in itself took a substantial amount of time...

\footnotetext{
${ }^{144}$ Dallah UKSC above $\mathrm{n} 1$ at [31].

${ }^{145}$ See Dallah HC above n 9 at [81], [82], Dallah CA above n 10 at [20].

${ }^{146}$ See Dallah HC above n 8 at [81], [82], Dallah $C A$ above n 10 at [21], Dallah UKSC above n 1 at [21].

147 These are set out at para 133 and essentially relate to: 1 A tribunal has power to decide jurisdiction under ICC Rules; 2. It is therefore competent tribunal to do so; 3. Under French law the arbitration agreement is distinct from the underlying contract; 4.The FPA has not been set aside by the French court who are the supervisory court; 5.GoP has confirmed it does not intend to apply to the French court to set aside the FPA; 6.Therefore under French law the FPA is valid and res judicata in regard to the dispute;7.The English court should recognise the FPA as final and conclusive.

${ }^{148}$ Dallah $H C$ above $n 9$ at [54].
} 
having carefully considered the advice provided by its French lawyers, [the GoP] has decided not to challenge the award in France.

Although the High Court judgment indicated Dallah relied on the Court of Appeal decision in Svenska Petroleum Exploration ABv Republic of Lithuania ${ }^{149}$ it would seem Dallah effectively sought endorsement of the decision made by the earlier judgments of Mr Teare QC and Gloster J. ${ }^{150}$ In that case, the question was whether an arbitrators' award on jurisdiction was final and conclusive if it could no longer be challenged under the law of the courts with supervisory jurisdiction over the arbitration.

In holding that it was, and that the State was bound by issue estoppel, Gloster J noted the possibility that the Interim Award had indeed become final and conclusive under Danish law was unsurprising. The position would be similar for English arbitration proceedings under sections 31 and 73 of the English Arbitration Act $1996 .{ }^{151}$ However the Court of Appeal upheld the decision of Gloster $J$ for different reasons, noting "debate about the effect of the first award" ceased to have any effect following its finding that the Government had agreed to refer its disputes to arbitration."

4. Whether the court has, and whether it should exercise the discretion to enforce the award even if ground under 103(2) (b) of the Arbitration Act 1996 (UK) were established.

Finally, Dallah argued even in the event the Government could establish a ground under s 103(2) (b) the court had discretion under Article V, and should exercise that discretion and refuse to overturn the decision of an arbitral tribunal. Thus, it was submitted, would give effect to the "pro enforcement" nature of the New York Convention.

\footnotetext{
${ }^{149}$ Svenska Petroleum Exploration AB v Republic of Lithuania [2006] EWCA Civ 1529.

${ }^{150}$ Svenska Petroleum Exploration AB v Republic of Lithuania [2005] EWHC 9 (Comm), Svenska Petroleum Exploration AB v Republic of Lithuania [2005] EWHC 2437. In those proceedings, Svenska sought enforcement of a second arbitral award against Republic of Lithuania and AB Geonafta. When this was opposed on grounds of state immunity. Svenska sought to have the opposition struck out on the basis the first award provided a complete answer to that claim. Mr Teare dismissed the strike out proceedings. When the case went before Gloster J, there were three main issues for determination. However the primary arguments were whether the first award was conclusive, and whether the decision of Mr Teare was an issue estoppel on that point. Gloster J .held the earlier judgment of Mr Teare QC merely decided that the State's claim to immunity should not be struck out or dismissed as being hopeless on the grounds of issue estoppel:. The issue of issue estoppel had not been decided.

${ }^{151}$ Svenska Petroleum Exploration AB v Republic of Lithuania [2005] EWHC 2437 at [62].

${ }^{152}$ Svenska Petroleum Exploration AB v Republic of Lithuania [2006] EWCA Civ 1529 at [92].
} 


\section{The decision of the English courts}

To speak of only two questions in Dallah belies the scope of issues that arose. In the High Court, Aikens J identified eight issues for determination, ${ }^{153}$ while in the Supreme Court Lord Mance and Lord Collins identified six distinct questions. ${ }^{154}$

The scope of issues to be decided reflects the particular facts of the dispute which ultimately required the English courts to wrestle with a number of contentious issues. These included the binding of non-signatories, choice of law, the relevance of state immunity, the existence and application of transnational law principles, discharging the burden of proof under the New York Convention, as well the doctrine of competencecompetence, and issue estoppel. All required an examination of the relationship between national courts and arbitral proceedings where an arbitral tribunal has already ruled on its own jurisdiction, as well as the nature of the relationship and the respective role of the national courts at the arbitral seat, and at the place of enforcement.

153 Dallah HC above n 9 at "F" [58] - [73]. The eight issues were: (1) What was the correct construction of section 103(2)(b) of the Arbitration Act 1996 (2) what was the scope of the enquiry that the court has to undertake when a challenge to an arbitral award under section 103(2)(b) was made (3) what are the French law principles by which to decide whether the Government of Pakistan was and is bound by the arbitration clause (4) If entitled to take account of Pakistani law, the effect of Article 173 of the Pakistan Constitution in terms of capacity to bind the Government of Pakistan (5) whether, on application of the relevant principles of French law, whether Government of Pakistan is bound by the arbitration Agreement (6) whether, even if conclude Government of Pakistan is not bound under French law has the burden of proving that arbitration agreement is not valid to the relevant standard been discharged (7) whether, even if agreement is not considered valid, would an issue estoppel arise from the first partial award preventing the Government of Pakistan from avoiding the order and (8) whether the court, even if it did find the agreement was not valid and there was no question of issue estoppel, should exercise a discretion and recognise the award.

154 For Lord Mance: (a) what is meant by the law of the country where the award was made (b) what are the provisions of that law as regards the existence and validity of an arbitration agreement (c) what is the nature of the exercise which an enforcing court must undertake when deciding whether an arbitration agreements existed under such law? And (d) what is the relevance of the fact that the arbitral tribunal has itself ruled on the issue of its own jurisdiction; For Lord Collins (a) the role of the doctrine that the arbitral tribunal has power to determine its own jurisdiction or Komptenez-Kompetenz or competence-competence (b) the application of arbitration agreements to non-signatories (including States) in French law, and the role of transnational law or rules of law in French law (c) whether renvoi is permitted under the New York Convention (and therefore the 1996 Act) and whether the application by an English court of a reference by French law to transnational law or rule of law is a case of renvoi. There is also the subsidiary issue of whether the court should exercise discretion to enforce the award Dallah UKSC above n 1 at [13] and [73], [74] respectively. 
At every level, the English courts held the proceedings were to be conducted by way of a re-hearing not simply a review of the arbitrator's decision: the enforcement court effectively re-hearing the matter as a first instant court was unrestricted by any findings of fact made by the tribunal in a preliminary award on substantive jurisdiction. Significantly, a re-hearing under English law includes hearing evidence direct.

On the English courts assessment of the French law, and of the facts, the Government of Pakistan was not a party to the arbitration agreement. The Government of Pakistan succeeded in opposing the award in the English High Court on the basis the agreement was not valid under the law to which it was subject. Subsequent appeals by Dallah to the Court of Appeal and Supreme Court failed.

\section{Proceedings before Paris Cour d'Appel}

The English courts did not have the last word. Before the hearing of the Supreme Court, Dallah had sought a stay of the English proceedings. This was pending the outcome of its application, made on 19 August 2009, to enforce the award in France. The application for a stay was refused by the Supreme Court on 25 January 2010 ${ }^{155}$ However, following the application by Dallah to enforce the award in France, the Government of Pakistan sought to have the award set aside. The sole issue before the Paris Court d'Appel was whether the Government was party to the Agreement. The Paris court released its decision shortly after the United Kingdom Supreme Court.

The French Court rejected the Government application to set aside the award, holding the Government was a proper party to the agreement, and was bound by the arbitration clause. ${ }^{156}$ Significant costs were awarded to Dallah. ${ }^{157}$ No appeal was made to the Cour de Cassation. ${ }^{158}$

This then is the 'pathological' result. Two national courts reaching different conclusions, on the same arbitral proceedings, despite applying the same law to the same facts. Moreover, as Gary Born observes, the decisions were reached in two national courts, after relitigating the question of jurisdiction some ten years after the decision of the

\footnotetext{
${ }^{155}$ Dallah UKSC above $\mathrm{n} 1$ at [10].

${ }^{156}$ Gouvernement du Pakistan v Societe Dallah Real Estate \& Tourism Holding Co, Cour d'appel, de Paris, Pôle 1 - Ch.1, n 09/28533 (February 17, 2011).

${ }^{157} € 100,000$ reportedly "a large amount by the standards of French litigation" see Jacob Grierson and Mirreille Taok, "Dallah: Conflicting Judgments from the U.K Supreme Court and the Paris Cour d'Appel “(2011) 28(4) J. Int Arb 407 at 414.

${ }^{158}$ Although there were early indications an appeal had been filed there is no record of it proceeding.
} 
arbitral tribunal, and more than fifteen years after the events that gave rise to the dispute. ${ }^{159}$ This hardly seems an outcome intended under the New York Convention, or one that serves any of the parties, let alone the objectives of the international arbitral process.

The following sections (Parts IV and V) analyse how the English Court decided the question of whether the Government of Pakistan was a party to the arbitration agreement with Dallah, and the process by which that question should be determined. It first looks at the justification for de novo review, before analysing how the English Court applied the facts to French law - and "how two courts applying the same law to the same facts can reach contrary decisions." 160

Part VI later considers whether holding that a court at the place of enforcement is always bound to decide a matter de novo serves the objectives of international commercial arbitration, or is necessary to promote the fundamental integrity of arbitral proceedings.

${ }^{159}$ Gary B Born and Michal Jorek "Dallah and the New York Convention" (April 2011) Kluwerblog $<$ www.kluwerblog.com>.

${ }^{160}$ Nicholas Bouchardie, Paul Brumpton, Christophe von Krause, Christophe Seraglini and Robert Wheal "Insight: In Dallah, the Paris Court of Appeal and UK Supreme Court Reach Contrary Decisions Applying Same Law to Same Facts" (2011) White \& Case Newsletters <www.whitecase.com>. 


\section{The case for de novo review}

The English proceedings involved two foreign entities, in respect of property dealings not connected with England, following a decision of an arbitral tribunal seated in Paris. The court proceedings occurred in the context of a domestic statute regarded as "pro arbitration', giving effect to an international framework with a "pro enforcement policy" All of this sits against a general recognition that arbitration is the preferred method of resolving international commercial disputes, and the objective of promoting the finality of arbitral awards.

Despite this, the English courts all agreed on the approach of a court when enforcement was opposed. In the High Court Justice Aikens held the exercise was a re-hearing, not a review, ${ }^{161}$ the approach and the conclusion on that point then confirmed by the Court of Appeal. ${ }^{162}$ The Supreme Court endorsed both court decisions: Lord Mance stated in conclusion "It follows that Aikens J and the Court of Appeal were right in the conclusion they reached and that Dallah's appeal to this court must be dismissed" while Lord Collins showed his hand early, his introductory paragraph, confirming the appeal "from the excellent judgements" of Aikens $\mathrm{J}$ and the Court of Appeal should be dismissed. ${ }^{163}$ Moreover, there was no dissenting judgment.

Notwithstanding this unanimity of decision, the justification for de novo review is not compelling. The Court addressed the question of the scope of enquiry first, purely as a matter of law. However the manner by which the Court approached the legal issues strongly suggests they were influenced by their view on the second issue - namely that on the facts the Government of Pakistan was not a party to the arbitration agreement. As Part V will discuss, the Court's approach to consent was influenced by English contract law theory. However domestic law also characterised the approach to interpretation of the New York Convention and its application. More fundamentally (and at all levels), the Court appeared to conflate the question of the court's task and how it should fulfil it. Overall, it is difficult not to conclude that the English Court was striving to get to the "right result" - insofar as it was right by English law standards.

\footnotetext{
${ }^{161}$ Dallah $H C$ above $\mathrm{n} 9$ at [84]

${ }^{162}$ Dallah CA above n 10 at [22] per Lord Justice Moore-Bick, at [64] per Lord Justice Rix, at [92] per Lord Justice Ward.

${ }^{163}$ Dallah UKSC above n 1 at [70] per Lord Mance, and at [71] per Lord Collins.
} 


\section{A Approach to Interpretation of the New York Convention}

The proceedings required the Court to interpret and apply the domestic law provisions where the validity of an arbitration award was challenged on grounds equivalent to article V (1) (a) of the New York Convention.

The onus was on the Government of Pakistan, as the party opposing enforcement, to demonstrate the agreement was not valid under the law to which it was subject. ${ }^{164}$ This required establishing it was not a party to the arbitration agreement under French law, notwithstanding the tribunal finding otherwise. The Court's task was to decide if the exception under the Convention had been proved, but how it should fulfil that function also had to be determined.

In its submissions for a less interventionist approach, Dallah relied heavily on the "pro enforcement" approach of the New York Convention. This formed the foundation for a two pronged attack, arguing first for a limited review, and secondly, a high threshold for intervention by a court on review. Essentially, Dallah argued the English courts, when faced with enforcement proceedings, should defer both to the Court at the arbitral seat, and to the arbitral tribunal. Neither proposition was accepted and the Supreme Court was unequivocal in agreeing an independent determination of the issues was required.

\section{Statutory Interpretation}

Dallah's argument that the Convention called for a limited review was rejected largely on the basis of the plain language of s 103(2) (b) Arbitration Act 1996 and by extension article V (1) of the New York Convention. The High Court, the Court of Appeal and the Supreme Court all relied on the text to justify their conclusion that the courts function to decide was by way of re-hearing.

Notwithstanding the reliance on statutory interpretation, no reference was made to interpreting the text in light of its purpose, or indeed, any express reference to domestic or international principles of interpretation. Some reference to the obligations and principles under the Vienna Convention 1969 might reasonably be expected even within a common law system that has to give effect to international conventions through domestic law. As an instrument of international law generally, and with its goal of

${ }^{164}$ Art V (1) (a) New York Convention 1958. 
uniform treatment of arbitral awards more specifically, context sensibly dictates the international principles as a starting point for consideration.

In comparison, the Vienna Convention 1969 is recognised as the starting point for interpretation of the New York Convention by the International Council for Commercial Arbitration. The ICCA Guide to Interpretation of the New York Convention (Handbook for Judges) ${ }^{165}$ emphasises the autonomous terms of the Convention and cautions against interpreting the provisions by reference to domestic law. Arguably, looking outward to the international context is also required as a matter of domestic law under the Arbitration Act 1996. This follows "the radical nature of the changes" ${ }^{166}$ wrought under that legislation, which reflect international influences: ${ }^{167}$

The Act has however given English arbitration law an entirely new face, a new policy, and new foundations. The English judicial authorities . . . have been replaced by the statute as the principal source of law. The influence of foreign and international methods and concepts is apparent in the text and structure of the Act, and has been openly acknowledged as such. Finally, the Act embodies a new balancing of the relationships between parties, advocates, arbitrators and courts which is not only designed to achieve a policy proclaimed within Parliament and outside, but may also have changed their juristic nature."

Instead, in the High Court Aikens J simply considered he was bound by the wording of the Arbitration Act 1996 itself. Despite saying its words "reflected faithfully that of the Convention" Aikens J immediately went on to construe its meaning by reference to English civil proceedings. Aikens $J$ then concluded the requirement on the party opposing the award to "prove" one of the specified matters "must mean, in the context of English civil proceedings, prove the existence of the relevant matters on the balance of probabilities." 168

Noting that all of the matters specified under section 103(2) (a)-(e) Arbitration Act 1996 (including questions of foreign law) were question of fact, Aikens J held the exercise was

\footnotetext{
${ }^{165}$ ICCA Guide to Interpretation of the New York Convention (Handbook for Judges) above $\mathrm{n} 46$ at Ch I.I.

${ }^{166}$ Lesotho Highlands v Impregilio SpA [2005] UKHL 43, [2006] 1 AC 221at [17] per Lord Steyn.

${ }^{167}$ Lesotho Highlands v Impregilio SpA Above n 166 at [17] citing Lord Mustill and Stewart Boyd QC Commercial Arbitration (2001 Companion Volume to the Second Edition, Preface (Butterworth's, Canada, 2001). Stewart Shackleton "The Internationalisation of English Arbitration Law" (2000) 11 (1) ICC International Court of Arbitration Bulletin Vol. 16.

${ }^{168}$ Dallah $H C$ above n 9 at [82].
} 
a re-hearing, and a party opposing enforcement was entitled to ask the court "to reconsider all relevant evidence on the facts (including foreign law), as well as apply relevant English law." 169 Aikens J proceeded to do just that, hearing oral evidence from the party's experts on French and Pakistani law directly.

Dallah's appeal to the Court of Appeal was based on four main points, including that the judge adopted the wrong approach to deciding whether the Government of Pakistan had proved that arbitration agreement on which Dallah relied was not valid. ${ }^{170}$ The comments of Lord Justice Moore-Bick do suggest that part of Dallah's argument was based on the absence of any reference to principles that apply when a domestic statute is implementing an international convention.

Lord Justice Moore-Bick accepted the general principle that legislation should be construed with regard to the convention to which it gives effect, but considered there was no reason to think the Judge was not alive to it, saying: ${ }^{171}$

In the absence of any authority, either in this country or abroad, which tends to support the conclusion that the language of Article V. 1 is to be given a meaning different from that which it naturally bears and in light of the close similarity of language between the Convention and the statute, I think the judge was right to treat the question as one of statutory interpretation and that his conclusion on the meaning of section 103(2) was clearly correct.'

Similarly, in the Supreme Court Lord Mance stated that he did not consider that either Article V (1)(a) New York Convention nor s.103(2)(b) Arbitration Act 1996 hinted at any restriction on the scope of review, stating "the language points strongly to ordinary judicial determination of that issue." Likewise, rejecting the submission that the Act called for a limited review, or deference to the tribunal, Lord Collins said "There is

${ }^{169}$ Dallah $H C$ above $n 9$ at [82] \& [83].

${ }^{170}$ Dallah $C A$ above n 10 at [11]. The four grounds were (1) The judge adopted the wrong approach to deciding whether the Government of Pakistan had proved that arbitration agreement on which Dallah relied was not valid; (2) That although the judge's finding of the relevant principles of French law were open to him on the evidence, he failed to apply them correctly to the material before him; (3) That the Government of Pakistan was estopped from denying that the arbitration agreement was valid; and (4) That even if the award was not valid; the Judged erred in not exercising his discretion in favour of enforcing it. The principal judgment in the Court of Appeal was given by Moore Bick LJ with Rix LJ offering further observations on the issues of estoppel and discretion. Ward LJ agreed the appeal should be dismissed for the reasons given by Moore-Bick and Rix LLJ.

${ }^{171}$ Dallah $C A$ above n 10 at [22] per Lord Justice Moore-Bick. 
simply no basis for departing from the plain language of article $\mathrm{V}$ (1) (a) as incorporated by s 103(2) (b)."

Interpretation, under domestic and international principles, requires regard to both the text and the purpose. ${ }^{173}$ The purpose of the New York Convention is "to promote international commerce and facilitate the settlement of disputes through arbitration." ${ }^{174}$ Yet, Dallah's arguments around the pro enforcement nature of the Convention largely fell on deaf ears.

The purpose of the Convention was barely considered by Justice Aikens, Lord Justice Moore-Bick or Lord Mance. Only Lord Collins made a brief reference to the "pro enforcement policy" when considering whether deference was required to the tribunal's decision, acknowledging the trend "both national and international to limit reconsideration of the findings of arbitral tribunals, both in fact and in law." ${ }^{175}$ However, in almost the same breath, Lord Collins then indicated the decision to substantively review is not discretionary: ${ }^{176}$

It follows that the English court is entitled (and indeed bound) to revisit the question of the tribunal's decision on jurisdiction if the party resisting enforcement seeks to prove that there was no arbitration agreement binding upon it under the law of the country where the award was made.

It is not clear from the statement of Moore Bick LJ in the Court of Appeal whether it was the case that no authority was put before it, or, if the court disregarded it. In any case, the absence of authority on a specific point would suggest more of a need to engage with the text and the Convention, not less.

The approach in Dallah can be contrasted to that taken in more a recent decision of the United Kingdom Supreme Court in Ust-Kamenogorsk Hydropower Plant JSC (Appellant)

\footnotetext{
${ }^{172}$ Dallah (UKSC) above $\mathrm{n} 1$ at [101] per Lord Collins.

${ }^{173}$ Art 31(1) Vienna Convention on Law of Treaties 1969 requires a treaty to be interpreted in good faith, in accordance with the ordinary meaning to be given to the terms of the treaty in their context and in light of their purpose in light of its object and purpose .

${ }^{174}$ ICCA Handbook above 46 at Ch. I.2

${ }^{175}$ Dallah UKSC above n 1 at [101].

${ }^{176}$ Dallah UKSC above n 1 at [104] per Lord Collins.
} 
$v$ AES Ust-Kamenogorsk Hydropower Plant LLP (Respondent). ${ }^{177}$ In that case, the question of whether the English Court could issue an anti-suit injunction even in the absence of an actual, proposed or intended arbitration was confirmed. The Supreme Court fully engaged with the issue as to the policy and legislative intent under the Arbitration Act 1996 and Supreme Court legislation. The difference perhaps being, in that case, it was used to justify the interventionist powers of the Court in support of arbitration, notwithstanding the somewhat infamous West Tankers decision. ${ }^{178}$

In an Australian case decided shortly after the Supreme Court decision in Dallah, the policy of the New York Convention was considered directly relevant. The 'pro enforcement' approach and what this meant was discussed at length in the first instance decision, and subsequent appeal, of Altain Khuder LLC v IMC Mining \& IMC Mining Solutions. ${ }^{179}$

Like Dallah, Altain Khuder involved a party resisting enforcement of a foreign arbitral award, primarily on the basis that the entity against whom the award was given was not a party to the arbitration agreement. Unlike Dallah, the initial application for enforcement was successful. ${ }^{180}$ On appeal, the Victorian Supreme Court of Appeal expressly acknowledged the pro enforcement policy of the Convention: ${ }^{181}$

..... The Act, and the Convention, reflect what is often described as a "pro enforcement bias' or policy. What that means is this. The Act, and the Convention, recognising the role and importance of arbitration in international trade and

$\overline{177}$ Ust-Kamenogorsk Hydropower Plant JSC (Appellant) v AES Ust-Kamenogorsk Hydropower Plant LLP (Respondent) [2013] UKSC 35.

${ }^{178}$ West Tankers Inc v Allianz SpA [2009] 1 AC 1138.

${ }^{179}$ Altain Khuder LLC v IMC Mining \& IMC Mining Solutions [2011] VSC 1 and IMC Aviation Solutions Pty Ltd v Altain Khuder LLC [2011] VSCA 248.

${ }^{180}$ Altain Khuder LLC v IMC Mining \& IMC Mining Solutions [2011] VSC 1 at [59]. Somewhat ironically, the Supreme Court (at first instance) referred to Dallah with approval, considering it supported the plaintiffs case - notwithstanding the plaintiffs attempt to distinguish it, or in the alternative, submitting that Dallah was wrongly decided.

${ }^{181}$ IMC Aviation Solutions Pty Ltd v Altain Khuder LLC [2011] VSCA 248 at [128] per Hansen JA and Kyrou AJA. Chief Justice Warren also notes the pro enforcement policy saying "The New York Convention is widely recognised in international arbitration circles as having a 'pro-enforcement' policy" at [45] fn 16 citing both ICCA's Guide to the Interpretation of the 1958 New York Convention (2011), and (curiously in light of the above discussion) Dallah [2010] UKSC 46; [2011] 1 AC 763, [101] (Lord Collins). However this did not prevent the Court deciding there was a threshold burden for a party seeking to enforce an award. See discussion at Part V. 
commerce and the certainty and finality of awards, has simplified the procedure for enforcing foreign arbitral awards while also limiting the grounds upon which the enforcement of such an award may be resisted and placed the onus of establishing those grounds upon the party resisting enforcement. In Redfern and Hunter on International Arbitration, it is said of the expression 'a pro-enforcement bias' that it 'means that whilst it may be possible to challenge an arbitral award, the available options are likely to be limited.' Sir Anthony Mason has described the objective of the Convention as being 'to encourage the recognition and enforcement of commercial arbitration agreements in international contracts and to unify the standards by which agreements to arbitrate are observed and arbitral awards are enforced'.

Conversely in Dallah the Court expressed statements not easily reconciled with the notion of a pro enforcement bias. In the now well recognised tennis analogy, Lord Mance said that "Dallah starts with the advantages of service, it does not also start fifteen or thirty love up"182 to which Born replied: ${ }^{183}$

Rather if the metaphase is to be pursued Dallah had already won an entire match, which concluded with a presumptively valid arbitral award - and the question was whether the outcome of that match should be ignored in recognition proceedings.

The Australian approach and the relevance of the purpose of the Convention to interpretation of the burden of proof are discussed further below. ${ }^{184}$ The distinction between the Australian and the English approach may be influenced in part, by the different statutory context. Although Part I to the English Arbitration Act sets out the general principles which form the foundation of the Act and guide its construction, ${ }^{185}$ these do not apply to Part III which governs enforcement of foreign awards. ${ }^{186}$

182 Dallah UKSC above n 1 at [30] per Lord Mance.

183 Gary Born "Dallah and the New York Convention" (7 April 2011) Kluwer Arbitration Blog $<$ www.kluwerarbitrationblog.com.>.

${ }^{183}$ G Born International Commercial Arbitration above n 16 at 1206.

184 See Part V.

${ }^{185}$ Part I deals with Arbitration pursuant to an arbitration agreement where the seat of arbitration is in England, Wales, or Northern Ireland (s 2(1) Arbitration Act 1996 (UK). The general principles are stated at section 1 Arbitration Act 1996 (UK): (a) The object of arbitration is to obtain the fair resolution of disputes by an impartial tribunal without unnecessary delay or expenses (b) the parties should be free to agree how their disputes are resolved subject only to such safeguards as are necessary in the public interest (c) in matters governed by this Part the court should not intervene except as provided by this Part. These principles continued to affirm the courts role in supporting the arbitral process. 
Conversely, the Australian International Arbitration Act 1974 (IAA) includes a section setting out the objects of the $\mathrm{Act}^{187}$ which refer to the facilitation of international trade, facilitating the use of arbitration agreements, facilitation of the recognition and the enforcement of arbitral awards "made in relation to international trade and commerce"188 as well as the relevant international conventions the Act gives effect to. In addition s 39 IAA sets out those matters a court must have regard to when faced with proceedings to which the IAA apply, which include "the fact" that: ${ }^{189}$

(a) arbitration is an efficient, impartial, enforceable and timely method by which to resolve commercial disputes; and

(b) awards are intended to provide certainty and finality.

The changes to the legislative provisions reflect directly, the attempt to rectify the problem of purely domestic influences affecting interpretation of international conventions which had been identified in Australia. ${ }^{190}$ These amendments were regarded as necessary to mitigate any risk that obiter comments in the 1995 decision Re Resort Condominium International Inc ${ }^{191}$ (where the Supreme Court of Queensland suggested there was a residual discretion to refuse to enforce awards on grounds other than those specified in the IAA), might be followed in future decisions. Those obiter comments were largely based on a textual interpretation including the words "may enforce" foreign awards, and the failure of the Australian legislature to include the words "only if" from Article V NYC in section 8(5) IAA. This allowed the court to create a distinction

${ }^{186}$ Part III of the Arbitration Act 1996 deals with the recognition and enforcement of certain Foreign Awards. The recognition and enforcement of New York Convention awards are governed at ss $100-104$, with sections 102 and 103 the Arbitration Act 1996 re-stating, for the most part, the Convention requirements for recognition and the limited grounds on which that may be refused.

${ }^{187}$ S2D IAA International Arbitration Act 1974 (Aus).

${ }^{188}$ s2D (a) - (f) International Arbitration Act 1974 (Aus). The three Conventions referred to are the New York Convention, the UNICTRAL Model Law, and the Convention in the Settlement of Investment Disputes between States and Nationals of Other States.

${ }^{189}$ s39 (2) (b) IAA (Aus).

${ }^{190}$ In addition to express provisions requiring courts "to have regard to the objects of and intention behind the IAA" the addition of a new s8 (3A) made clear that the grounds prescribed at sect s8 (5) and 8(7) of the IAA were the only grounds that a court may rely on to refuse to enforce a foreign award. Gregory Nell S.C, "Recent Developments in the Enforcement of Foreign Arbitral Awards in Australia" (2012) 26 (1) MLLANZ Journal 26 (paper originally presented at fall meeting of the Maritime Law Associations of the United States, Canada, Australia and New Zealand in Hawaii 2011).

${ }^{191}$ Resort Condominium International Inc v Bolwell [1995] 1 Qd 406 at 426-427 discussed in Nell above n 191 at 31. 
between the restrictive terms of the Convention and the Australian legislation. ${ }^{192}$

This proves the rule rather than justifying the exception and serves to emphasise the need for vigilance when domestic courts are applying provisions that implement the New York Convention. The success of the New York Convention requires national legislatures and courts in different contracting states to adopt uniform interpretations of the convention. ${ }^{193}$ Uniform treatment requires all Courts to have regard to the same fundamental principles, which will not occur when those are drawn from a national law framework.

The failure to engage with the purpose and policy of the Convention when interpreting the domestic requirements is surprising given recognition the case was of international importance. ${ }^{194}$ The simplistic approach to interpretation is inappropriate for an international case but also represents a missed opportunity.

The brevity of the Convention lends to a constitutional, rather than detailed legislative structure and leaves a "substantial role" for national law and national courts. ${ }^{195}$ This, together with the limitations inherent in any international law model, means that "fine tuning the points of intersect between the roles of the court and the tribunal has to take place outside of its literal text."196

Developing autonomous principles, which are capable of broad application, is essential to meet the 'needs of modern practice.' ${ }^{197}$ For this reason, further fine tuning and elucidation of the principles governing a pro enforcement purpose would have been a welcome contribution from the Supreme Court. Instead the Court managed to evade engaging with a fundamental objective of the Convention.

\section{Relevance of cases decided under section 67 Arbitration Act 1996 (UK)}

The domestic influence on interpretation was further evidenced by the reliance on cases decided under s 67 of the Arbitration Act 1996 in Dallah.

\footnotetext{
192 Nell above n 191 at 32.

${ }^{193} \mathrm{G}$ Born International Commercial Arbitration above n 16 at 101.

${ }^{194}$ Dallah UKSC above $\mathrm{n} 1$ at [71] per Lord Collins.

${ }^{195}$ G Born International Commercial Arbitration above n 16 at 95, 101.

${ }^{196}$ Amokura Kawharu “Arbitral Jurisdiction” (2008) 23 New Zealand Universities Law Review 238 at 264.

${ }^{197}$ Explanatory Note by UNCITRAL Secretariat on the 1985 Model Law above n 67 at A.1.6.
} 
Section 67 permits challenges to the substantive jurisdiction of a tribunal when England is the seat of arbitration. Before the High Court Counsel for Dallah distinguished the case from appeals under section 67 of the Arbitration Act 1996, and the line of English authorities that held such cases were by way of re-hearing.

The English authorities referred to were those that followed the decision in Azov Shipping Co. $v$ Baltic Shipping Co. ${ }^{198}$ In that case there was a dispute as to whether Azov was a party to an agreement entered into by a number of shipping companies to deal with containers following the disintegration of the Soviet Union. Following a three day hearing, an arbitral tribunal had determined that Azov was a party to the agreement. Although Azov participated in the arbitral hearing on jurisdiction it did so with full reservation on its position.

The arbitrator heard oral evidence and determined a number of matters of fact and foreign law. The arbitrator acknowledged that on the key issue of whether Azov was or was not a party to the award he had "no hesitation in conceding that I have had some uncertainty." 199 Azov then challenged that award under s 67 of the 1996 Act, where Rix J had to consider the nature of his task:

Where a full scale hearing on jurisdiction has been heard before the arbitrator under s. 30 and there is a challenge to his award on jurisdiction under s. 67, can the challenger seek an order from the court as to directions (for the purpose of the relevant arbitration agreement) which enable him to present his case and challenge the opposing party's case on question of jurisdiction with the full panoply of oral evidence and cross examination, so that, in effect, the challenge becomes a complete re-hearing of all that has already occurred before the arbitrator?

After canvassing the options open to a party challenging the substantive jurisdiction of an arbitrator under the 1996 Act, Rix J turned to consider the application of RSC Ord 74, r 13. RSC Ord 74, r 13 provided for the Court to "give such directions as to the conduct of the arbitration application as it thinks best adapted to secure the just, expeditious and economical disposal thereof." 200 Although Rix J considered there was force in Baltics submission that it would be "neither just, nor expeditious, nor economical to permit such a re-hearing" in the case before him, he concluded oral evidence should be permitted. ${ }^{201}$

\footnotetext{
${ }_{198}$ Azov Shipping Co. v Baltic Shipping Co. [1999] 1 Lloyds Rep 68.

${ }^{199}$ Azov Shipping Co. v Baltic Shipping Co. [1999] 1 Lloyds Rep 68 at [69].

${ }^{200}$ RSC Ord 74, r 13 referred at Azov Shipping Co. v Baltic Shipping Co. [1999] 1 Lloyds Rep 68 at [70].

${ }^{201}$ Azov Shipping Co. v Baltic Shipping Co. [1999] 1 Lloyds Rep 68 at [71].
} 
In contrast, in the context of a foreign award, Dallah submitted that international comity and the "pro arbitration approach" of the Convention and Part II of the Act suggested a limited review. ${ }^{202}$ As indicated above, the High Court disposed of the notion of a limited review in two paragraphs. Consequently, it was not clear from the judgment, whether in rejecting Dallah's policy argument, Aikens J was also rejecting Dallah's submission that decisions under section 67 of the Arbitration Act 1996 were irrelevant in the context of enforcement proceedings for a foreign award.

The Court of Appeal did consider the English decisions under s 67 of the Act relevant when it rejected Dallah's arguments for deference to the tribunal's findings, going on to say: 203

it is for similar reasons that our courts have consistently held that proceedings challenging the jurisdiction of an arbitral tribunal under section 67 of the Arbitration Act involves a full re-hearing of the issues and not merely a review of the arbitrators own decisions.

However Lord Justice Moore-Bick's reasons largely referred to the problem that deference to the tribunal's conclusions "would be to give the award a status which the proceedings themselves call into question." 204 This appears to ignore the fact that under the international framework foreign arbitral awards do have a status, with the New York Convention's presumption of validity. ${ }^{205}$ This presumption, its impact on interpretation of the scope of provisions for refusing recognition and enforcement, and the shift in onus it brings, represents another important distinction between the international and domestic contexts. $^{206}$

The influence of decisions by English courts under section 67 Arbitration Act 1996 was apparent in the reasoning of the Law Lords in the Supreme Court. With further reference

\footnotetext{
${ }^{202}$ Dallah $H C$ above $\mathrm{n} 9$ at [81].

${ }^{203}$ Dallah CA above n 10 at [21] per Lord Justice Moore Bick. The Court of Appeal did not specify the s. 67 cases referred, but in the High Court the decisions noted were those that followed Azov Shipping Co. $v$ Baltic Shipping Co and referred to in Peterson Farms Inc v C\& M Farming Ltd see above n 9 at [81] fn 41 (excluding The Republic of Serbia v Imageat International NV [2009] EWHC 2853 (Comm)).

${ }^{204}$ Dallah $C A$ above n 10 at [21].

${ }^{205}$ Art III New York Convention "Each Contracting State shall recognize arbitral awards as binding and enforce them in accordance with the rules of procedure of the territory where the award is relied upon..."

${ }^{206}$ ICCA Handbook above $\mathrm{n} 46$ at Ch II.I, II.1, and III.4.
} 
to Azov Shipping Co. v Baltic Shipping $\mathrm{Co}^{207}$ Lord Mance also referred to the entitlement, in the case of domestic awards, for a party to have a full judicial determination on evidence of an issue of jurisdiction under section 67 Arbitration Act 1996, and did not consider that the position differed when an English Court was asked to enforce a foreign award. Similarly, Lord Collins said: ${ }^{208}$

The consistent practice of the Courts in England has been that they will examine or re-examine for themselves the jurisdiction of arbitrators. This can arise in a variety of contexts including a challenge to the tribunal's jurisdiction under section 67 of the 1996 Act, or in an application to stay judicial proceedings on the ground that the parties have agreed to arbitrate.

The history and nature of s 67 of the Arbitration Act 1996 and the approach of the English courts is discussed in more detail in Part VI. For present purposes, the argument is simply that justifying de novo review of a foreign arbitral award in enforcement proceedings, by reference to cases decided under section 67 Arbitration Act 1996, is unhelpful (at best). More fundamentally, it is contrary to the principles underpinning the New York Convention which seeks to establish international principles by reference to international standards.

Section 67 refers to the law when England is the seat of arbitration. It is the law governing domestic arbitration. As discussed previously, there are legal, cultural and historical influences that colour a State's approach to arbitration.

The result of relying on principles developed from laws dealing with domestic arbitration was the very impetus for the UNCITRAL Model Law. Domestic principles were considered inappropriate for international cases as "traditional local concepts are imposed on international cases and the needs of modern practice are often not met". ${ }^{209}$ Avoiding the imposition of national norms through national courts is all the more pronounced in cases of enforcement, when the public policy of the state is not engaged. Although in a 1992 address, Lord Mustill, one of the arbitrators in Dallah, commented publicly that he "never understood why international arbitration should be different in principle from any other kind of arbitration" 210 there remain challenges unique to international arbitration

${ }^{207}$ Azov Shipping Co. v Baltic Shipping Co [1999] 1 Lloyds Rep 68.

${ }^{208}$ Dallah UKSC above n 1 at [96].

${ }^{209}$ UNCITRAL Model Law on Commercial Arbitration, Part 2, A. Background to Model law.

${ }^{210} \mathrm{G}$ Born International Commercial Arbitration above n 16 at 111, citing. M Mustill, Cedric Barclay Memorial Lecture, 1992 Arb. 159, 165. 
that have led to the development of the international framework. These include the "greater jurisdictional, choice of law and enforcement uncertainties in the international context and the need for predictability and certainty in international commerce."

For those reasons, the better approach to interpretation requires national courts to posit principles firmly within the international context, and to give due regard to the objectives of international arbitration. This follows simply because once proceedings have passed the gateway to come within the New York Convention, a State's obligations must be engaged, and interpretation of its provisions guided by its international context. ${ }^{212}$

Instead, the Court justified its conclusion by reference to the consistent practice of the courts in England being that they will examine or re-examine for themselves the jurisdiction of arbitrators. ${ }^{213}$ However, the traditional practice of English courts to exercise broad supervisory power, at least as a starting point, is not warranted (or justified) to meet the needs of modern commercial practice.

Changes wrought to English law arbitration laws have expressly been for the purpose of limiting the involvement of English Courts in international arbitration. During debate on the Arbitration Act 1979 a letter was read to the House of Lords as part of the debate on the status of London's arbitration law. The General Counsel of a large multinational corporation advised that he had issued instructions that Counsel in his department were "never to agree to the United Kingdom as a site for arbitration" following the recent experience of arbitration being captured by the English court. ${ }^{214}$

The criticism directed at the intervention of English law in the arbitral process was commented on by Lord Justice Saville in Departmental Advisory Committee on Arbitration Law ("The DAC") just prior to the enactment of the 1996 Arbitration Act 1996: ${ }^{215}$

there is no doubt that our law has been subject to international criticism that the courts intervene more than they should in the arbitral process, thereby tending to

\footnotetext{
${ }^{211}$ G Born International Commercial Arbitration (Kluwer Law International, Netherlands, 2009) at $111 \mathrm{fn}$. 660 .

${ }^{212}$ ICCA Handbook above $n 46$ at Ch VI.1.

${ }^{213}$ Dallah UKSC above n 1 at [96] per Lord Collins.

${ }^{214}$ Lord Hacking "The Story of the Arbitration Act 1979" (2010) 76 Arbitration 125-129 at 125.

${ }^{215}$ Departmental Advisory Committee report on Arbitration Law (DAC) Report on the Arbitration Bill, at 11, [21]-[22] referred to in Lesotho Highlands v Impregilio SpA above n 167 at [26].
} 
frustrate the choice the parties have made to use arbitration rather than litigation as the means for resolving their disputes.

More recently, the approach in Dallah has led to the aforementioned criticism by Gary Born and Charlie Caher where they described the decision as a "pathological" case, saying "...the decision accords scant deference to the arbitral process and the considered conclusions of arbitral tribunals." 216

Deference as a term is widely used in academic texts, commentary, and within judicial decisions across different jurisdictions. Yet reference to deference alone, without clearly expressing what that means and what it requires, can obscure the real questions that are in issue. Namely what is the responsibility of the tribunal in arbitration, and what is the function of the court in relation to the tribunal. How the English courts conceive of the relationship between national courts and arbitration proceedings can be seen in the Court's response to the core submissions by Dallah.

\section{B Response to Dallah's Core Arguments on the Scope of Enquiry}

Dallah argued the English courts, when faced with enforcement proceedings, should defer both to the Court at the arbitral seat, and to the arbitral tribunal.

The relevance of the court at the arbitral seat manifested itself in two quite distinct ways. On one hand, Dallah argued for a limited role of a court at the place of enforcement by reference to the broader role the Convention leaves for national courts at the arbitral seat. On the other, the fact that the award had not been challenged in France was relied on as a form of estoppel.

Further the enforcement court was required to give deference to the findings of the arbitral tribunal, Dallah arguing a court should only 'review' the tribunal's decision and whether there was a valid arbitration agreement, not conduct a re-hearing. The decision of the tribunal should be given strong evidential effect and where the tribunal's conclusions could be regarded as plausible or 'reasonably supportable' it should be accepted.

216 Charlie Caher and Gary Born "The Impact of Dallah" (2011) Kluwer Arbitration Blog $<$ www.kluwerarbitrationblog.com>. 
The manner in which the Supreme Court approached Dallah's core submissions seems more aligned with the traditional (and much maligned) supervisory roles that were exercised over arbitration by English courts. It is a far cry from the aspirational relationship between arbitration and national courts conveyed by Lord Wilberforce when the 1996 bill was passed: ${ }^{217}$

I would like to dwell for a moment on one point to which I personally attach some importance. That is the relation between arbitration and the courts. I have never taken the view that arbitration is a kind of annex, appendix or poor relation to court proceedings. I have always wished to see arbitration, as far as possible, and subject to statutory guidelines no doubt, regarded as a freestanding system, free to settle its own procedure and free to develop its own substantive law - yes, its substantive law. I have always hoped to see arbitration law moving in that direction. That is not the position generally which has been taken by English law, which adopts a broadly supervisory attitude, giving substantial powers to the court of correction and otherwise, and not really defining with any exactitude the relative positions of the arbitrators and the courts.

The Court rejected any suggestion that its function to decide was circumscribed by either the role of the Court at the arbitral seat, or as a consequence of the tribunal's determination on the existence of an agreement to arbitrate. However the Court conflated the question of its task and how it should fulfil it. Once it demonstrated it was to decide for itself whether there was an agreement to arbitrate, it seemed to inexorably follow that must be by way of a rehearing. This does not follow as a matter of logic or necessity.

\section{No primacy to court at the arbitral seat}

As set out above, Dallah's core submissions were based on its submission that the policy of the New York Convention gives primacy to the 'supervisory' court at the arbitral seat meaning only the supervisory court could undertake a substantive review.

\footnotetext{
$\overline{217}$ Lesotho Highlands v Impregilio SpA above n 167 at [18] per Lord Steyn, quoting Lord Wilberforce's speech during the second reading of the Bill in the House: Hansard, 18 January 1996 (568 HL Official Report, 5h Series, col 778).
} 
This argument, based in part on comity, ${ }^{218}$ rests on a distinction between 'primary' and 'supervisory' jurisdiction under the New York Convention. Although some academics and jurisprudence accept a hierarchy between the court of the seat of arbitration and the court of enforcement, ${ }^{219}$ these terms are not used in the New York Convention itself and their use has been attributed to an 'American invention'. 220

At its most basic, the argument was that as the Convention recognises that only the court at the arbitral seat can annul an award, the Convention gives primacy to that court. Consequently, only that court has jurisdiction to conduct a whole sale rehearing. The court at the place where enforcement is sought should conduct only a limited review, accepting any relevant findings of fact and decisions of the tribunal unless they can be shown to be clearly wrong.

As indicated earlier, Dallah identified a number of pragmatic reasons why the distinction between the primary and secondary jurisdiction was appropriate. This included legal certainty, as the court at the arbitral seat would be better placed to decide any question of law, and it would prevent the risk of different outcomes in enforcement was opposed in many different jurisdictions. ${ }^{221}$

Lord Collins was dismissive of the suggestion the Convention afforded primacy to the courts of the arbitral seat, in the sense it should be the only court to conduct a rehearing. Both Lord Mance and Lord Collins appeared to equate this with a suggestion there was an obligation to resist an award before the courts at the arbitral seat, which they did not accept the Convention required. ${ }^{222}$ This was also evident in the Court of Appeal where

$\overline{218}$ Dallah $H C$ above n 9 at [81], Dallah $C A$ above n 10 at [14] (Counsel for Dallah submitting that international comity and the "pro arbitration approach" of the Convention and Part II of the Act suggested a limited review).

${ }^{219}$ Julian Lew QC, "Does National Court Involvement Undermine the International Arbitration Process." (2008-2009) 24 Am. U. Int'l Rev. 489 at 494 "Under the [New York] Convention, 'the country in which, or under the [arbitration] law of which, [an] award was made is said to have primary jurisdiction over the arbitrate award. All other signatory States are secondary jurisdictions, in which parties can only contest whether that State should enforce the arbitral award."

${ }^{220}$ Jan Paulsson "Arbitration in Three Dimensions" LSE Law, Society and Economy Working Papers 2/2010 at <www.lse.ac.uk/collections/law/wps/wps.hm> (text of inaugural lecture), see Karaha Boda Co v Perusahaan Pertambangan Minyak Dan Gas Bumi Negara, 335 F 3d 357, 364 (5 $5^{\text {th }}$ Cie 2003), in re Karah Bodas Co v Perrusahaan Pertambangan Minyak Dan Gas Bumi Negara, 465 F. Supp. 2d 283 (S.D.N.Y 2006).

${ }^{221}$ Dallah $C A$ above n 10 at [19].

${ }^{222}$ Dallah UKSC above n 1 at [30] per Lord Mance, [103] per Lord Collins. 
Lord Moore-Bick similarly appeared to re-frame Dallah's submission, stating nothing in the Convention gave the courts at the arbitral seat primacy in the sense of expecting, "much less" requiring, and the court at enforcement to give effect unless successfully challenged in the supervisory court. The effect, he said, of requiring foreign courts to defer to the courts of the country where the arbitration has its seat, would be to reinstate in all but name the "double exequatur rule" which the convention displaced and would significantly increase the influence of the courts of that jurisdiction." 223

This appears to conflate the two limbs of Dallah's argument (the nature of the enquiry and the argument for estoppel), and misconceives the nature of double exequatur. The requirement for double exequatur under the Geneva Convention required the party who wished to enforce an award to first demonstrate that it had become binding at the place of arbitration. Dallah's submission does not lead to such a result. Rather, it suggests that a party opposing an award on the basis it should be set aside, should oppose that award at the place of arbitration either to prevent it becoming binding, or because that place is the only place that can annul or set aside the award.

Both Professor Park and Albert van den Berg have previously expressed views to this effect. ${ }^{224}$ As Professor Park notes, arguments about double exequatur ignore the relevance of Article II of the Convention which provides for the presumptive validity of a foreign award: ${ }^{225}$

This procedure avoids the considerable inconvenience involved in attacking an invalid award in each of the many states where the award might be enforced against the debtor's property. It also furthers uniformity, rather than allowing the issue to be decided differently by different States. Such uniformity increase fairness to the contesting party, who has an opportunity to resolve conclusively his objection to excess of arbitral jurisdiction in the State where he has been obligated to arbitrate.

$\overline{223}$ Dallah $C A$ above n 10 at [19].

${ }^{224}$ A van den Berg The New York Convention 1958 (1981) at 30 in context of a-national awards), W W Park "The Lex Loci Arbitri and International Commercial Arbitration" (1983) 32 International and Comparative Law Quarterly 21 at 30, and W. W Park, "Judicial Supervision of Transnational Commercial Arbitration: The English Arbitration Act of 1979" (1980) 21 Harvard International Law Journal 87 at 122. For a contrary view, arguing for de-localisation of arbitral awards see Jan Paulsson, "Delocalisation of International Commercial Arbitration: When and Why it Matters" (1983) 32 International and Comparative Law Quarterly 53, Jan Paulsson "Arbitration in Three Dimensions" LSE Law, Society and Economy Working Papers 2/2010 at <www.lse.ac.uk/collections/law/wps/wps.hm> (text of inaugural lecture).

${ }^{225}$ Park, "Judicial Supervision of Transnational Commercial Arbitration: The English Arbitration Act of 1979" above n 225at 122. 
Of course, the notion of resolving a dispute 'conclusively' presupposes that decision will have some preclusive effect. It is at this point that principles that simultaneously want to facilitate the recognition and enforcement of arbitral awards through limiting the involvement of national courts, and the interest in finality of litigation may conflict. Park identifies the tension as between two types of certainty: one related to the uniform application of legal norms and the other concerned with the adjudicatory forum. ${ }^{226}$ In this context, competing theories of arbitration can operate to frustrate a coherent framework, an issue not greatly assisted by the approach of the Supreme Court, in its quick dismissal of the role of the court at the arbitral seat.

Under both the Protocol and the Convention the place of Arbitration had particular prominence, often seen as being at the expense of party autonomy. ${ }^{227}$ These limitations contributed to the on-going development of international solutions, discussed earlier, and culminating in the New York Convention. In the lead up to the New York Convention, the appropriate balance between party autonomy and supervision of national courts was the subject of much debate. ${ }^{228}$ Early proposals from the ICC sought an entirely delocalised arbitral regime that would not be governed by any national law ${ }^{229}$ however these were opposed by the United Nation's Economic and Social Council (ECOSOC) who sought to fix arbitration firmly within national laws, and specifically law of the arbitral seat. A subsequent working party was tasked to reconcile the two positions and in its final form the New York Convention reflects the balance that was struck. ${ }^{230}$

The New York Convention gives effect to party autonomy (including the ability to select the law applicable to the arbitration and to agree the composition and procedures of the tribunal), while retaining a specific role for the law of the place where the award or under

\footnotetext{
$\overline{226}$ W. W Park "The Lex Loci Arbitri and International Commercial Arbitration" (1983) 32 International and Comparative Law Quarterly 21 at 29.

${ }^{227}$ G Born International Commercial Arbitration above n 16 at 1254.

${ }^{228}$ See for example ICC, Report and Preliminary Draft Convention adopted by the Committee on International Commercial Arbitration at its Meeting of 13 March 1953, reprinted in 9(1) ICC Ct. Bull. 32 (1998), and discussion in G Born International Commercial Arbitration above n 16 at $1254-1258$.

${ }^{229}$ G Born International Commercial Arbitration above n 16 at $1255 \mathrm{fn} 111$, citing A van den Berg The New York Arbitration Convention of 1958 (1981) .

${ }^{230}$ See Summary Record of the Seventeenth Meeting on the United Nations Conference on International Commercial Arbitration, UN Doc. E/CONF.26/SE.17, 10 (1958) at <www.uncitral.org and discussion> in G Born International Commercial Arbitration (Kluwer Law International , Netherlands, 2009) at 1254 1258.
} 
which the award was granted. In addition to the default choice of law rules, where the place of arbitration will govern in the absence of any express choice, the Convention reserves for the place of arbitration the power to annul or set aside an arbitral award.

The New York Convention clearly envisages the preclusive effect of an annulment at the place of arbitration. ${ }^{231}$ In addition to the express reference of the setting aside as a ground for refusing recognition and enforcement under article V (1) (e), this is emphasised by the provision to adjourn the decision on enforcement if an application for setting aside or suspension of the award has been made. ${ }^{232}$ By the time proceedings came to the Supreme Court such an application had been made to the French court. The Supreme Court refused to stay its proceedings, though its reasons are not clear. ${ }^{233}$

It is difficult to see a logical reason for the decision of the Supreme Court to refuse to stay its proceedings pending the outcome of the applications before the French Court. The prospect of simultaneous applications to enforce or set aside an award and the subsequent result of two courts having concurrent jurisdiction over the same arbitral proceedings ("Double Control") was recognised during the drafting of both the New York Convention and The Model Law. Double control was dealt with through the discretionary power given to a court (or competent authority) to adjourn its decisions and to require a party resisting enforcement to provide security. ${ }^{234}$

\footnotetext{
${ }^{231}$ Art V(1)(e) New York Convention 1958 "The award has not yet become binding on the parties, or has been set aside or suspended by a competent authority of the country in which, or under the law of which, that award was made." As to the preclusive effect in practice see Jan Paulsson above n 221 cf "...the current version of the New York Convention offers no possibility to recognise and enforce an award that has been set aside in the country of origin." A van den Berg "Enforcement of Arbitral Awards Annulled in Russia, case Comment on Court of Appeal of Amsterdam, April 28, 2009" (2010) Journal of International Arbitration 27(2) 197-198 at 196.

${ }^{232}$ Art VI New York Convention "If an application for the setting aside or suspension of the award has been made to a competent authority referred to in article V (1) (e), the authority before which the award is sought to be relied upon may, if it considers it proper, adjourn the decision on the enforcement of the award and may also, on the application of party claiming enforcement of the award, order the other party to give suitable security."

${ }^{233}$ The reasons are not stated in the decision and there is no separate judgment recording the details of the application or decision on the application for a stay.

${ }^{234} \mathrm{H}$ M Holtzmann and J E Neuhaus International Commercial Arbitration: Legislative History and Commentary (Kluwer, Boston, 1989), pp. 1062-1063, Gerald W Ghikas "A Principled Approach to Adjourning the Decision to Enforce under the Model Law and the New York Convention" Arbitration International (2006) Vol 22, No. 1, 53 at 1 "'Double control' refers to a situation where two different courts may be asked concurrently to determine the same issues, one in the context of an application to
} 
The application for a stay of the recognition proceedings may be regarded as unusual in one respect; namely, it was Dallah making the application. Most commentary seems to assume that the party making the application for a stay would be the party against whom the award was attempting to be enforced, and the exercise of the discretionary powers managed so as to ensure it is not used as dilatory tactic by a party avoiding enforcement.

In many cases that is likely to be so, but it is no less true that a party in the very situation Dallah found itself in - with an enforcement court applying foreign law to its resulting disadvantage - might view the prospect of exequatur from a court at the seat as the better route to take. Possibly, Dallah was boosted in the present case by the previous statement by the Government of Pakistan that it had decided not to initiate proceedings in France (following legal advice), notwithstanding its acknowledgement a decision in its favour could provide a basis for the English court to refuse recognition or enforcement under Article V(1)(e) New York Convention.

Although the commentary from the working group at the time article VI was drafted indicates that was the circumstance in mind at the time ${ }^{235}$ there is nothing in the text of the New York Convention that says the application can only be made by the party seeking annulment. The test is framed in the same way under the New York Conventions and s. 103(5) of the UK Arbitration Act 1996, and allows a court "if it considers it proper, [to] adjourn the decision on the recognition or enforcement of the award."

enforce an award, and one in the context of an application to set aside the same award. The discretion to adjourn the decision to enforce was to be available as a mechanism to avoid possibly conflicting decisions." 235 "The working party recommended the adoption of that article in order to permit the enforcement authority to adjourn its decision if it was satisfies than an application for annulment of the award for its suspension was made for a good reason in the country where the award was given. At the same time to prevent an abuse of that provision by the losing party which may have started annulment proceedings without a valid reason purely to delay or frustrate the enforcement of the award, the enforcement authority should in such a case have the right either to enforce the award forthwith or to adjourn its enforcement only on the condition that the party opposing enforcement deposit a suitable security. Summary Record of the Seventeenth Meeting of the United Nations Conference on International Commercial Arbitration, UN Doc.E/CONF.26/SR.17, 3-4(1958) available at <www.uncitral.org $>$. 
The key policy objective served by this discretionary power is to avoid concurrent review of the same issue by different court, and the prospect of conflicting court decisions. ${ }^{236}$ Yet that is precisely the outcome that resulted from the proceedings in Dallah.

In addition, both an application to enforce, and an application to set aside, had been made in France. The applications would stand or fall together, and only a decision of a French Court could potentially afford the Government of Pakistan a broader protection against enforcement in other jurisdictions under Article V(1)(e), than a decision on enforcement by an English court. ${ }^{237}$ A positive decision from a French court could have the effect of creating an estoppel or by way of precluding a defense under article $\mathrm{V}(1)$ (a) through reliance on Article V(1)(e). ${ }^{238}$

For that reason alone, the better approach would have been for the English Court recognise the French Court as the more appropriate court to hear and decide the issue and stay it proceedings. The fact it did not led to the very outcome the Convention seeks to avoid (conflicting court decisions), and lends support to the notion the English courts very much wanted to decide the issue for itself.

\section{No estoppel}

In rejecting the arguments for estoppel, the Supreme Court did not pick up on, or consider the distinction made by Lord Justice Rix in the Court of Appeal. Lord Justice Rix observed that as the awards were not English awards section 67 had no application, and if an analogy was to be made, the better analogy would be section 72, as the Government of Pakistan had taken no part in the arbitration. ${ }^{239}$

Perhaps this was in recognition that Lord Justice Rix did not address the fact that while the Government of Pakistan did not appear before the tribunal, it twice made submissions on the question of the tribunal's jurisdiction (albeit on a without prejudice basis). English law protects against a party sitting on its hands - an issue not canvassed in Dallah. An objection to the substantive jurisdiction of the arbitral tribunal must be raised at the time a

\footnotetext{
${ }^{236}$ See Seventh Secretariat Note, A/CN.(/264, para 5 in respect of the Article 36(2) Model Law, and see generally Gerald W Ghikas "A Principled Approach to Adjourning the Decision to Enforce under the Model Law and the New York Convention" Arbitration International (2006) Vol 22, No. 1, 53.

${ }^{237}$ By operation of article V (1) (e) New York Convention 1958.

${ }^{238}$ See comment at Dallah $C A$ above $\mathrm{n} 10$ at [91] per Lord Justice Rix.

${ }^{239}$ Dallah $C A$ above n 10 at [71] per Lord Justice Rix.
} 
party takes the first step, ${ }^{240}$ or if an issue arises during proceedings as soon as possible after. ${ }^{241}$

The English Act envisages that parties may refer jurisdiction to be determined by the court as a preliminary matter where substantial savings in costs may result. ${ }^{242}$ Critically, the right to object and the right to challenge the substantive jurisdiction under s 67 of the Act may be lost, where the party fails to raise the issue, or where following a decision by the tribunal that it does have substantive jurisdiction, fails to challenge the award within 28 days of the award, or decision following an arbitral process of appeal or review. ${ }^{243}$ Although a distinction is made where a party takes no part in proceedings, the English courts have applied those provisions in a strict manner. ${ }^{244}$

The purpose of s 72 of the Arbitration Act 1996 (UK) had been re-stated by the English Court of Appeal shortly before the decision in Dallah: ${ }^{245}$

A person who considers that he has not entered into an arbitration agreement is entitled to ignore its proceedings. He is entitled to say, in effect, that the arbitral proceedings are nothing to do with him. If he takes that course, his rights to claim relief from the court cannot be restricted because he did not participate in those proceedings. If, on the other hand, he participated in the proceedings, whether in

\footnotetext{
${ }^{240}$ s 31(1) Arbitration Act 1996 (UK).

${ }^{241}$ s 31 (2) Arbitration Act 1996 (UK).

${ }^{242}$ s 31(1) Arbitration Act 1996 (UK).

${ }^{243}$ ss 67, 70, 73 Arbitration Act 1996 (UK).

24472 Arbitration Act 1996 (UK) - 72 Saving for rights of person who takes no part in proceedings.

(1) A person alleged to be a party to arbitral proceedings but who takes no part in the proceedings may question-.

(a) Whether there is a valid arbitration agreement, .

(b) Whether the tribunal is properly constituted, or .

(c) what matters have been submitted to arbitration in accordance with the arbitration agreement,

by proceedings in the court for a declaration or injunction or other appropriate relief.

(2) He also has the same right as a party to the arbitral proceedings to challenge an award-

(a) by an application under section 67 on the ground of lack of substantive jurisdiction in relation to him, or

(b) by an application under section 68 on the ground of serious irregularity (within the meaning of that section) affecting him; and section 70(2) (duty to exhaust arbitral procedures) does not apply in his case.

${ }^{245}$ Broda Agro Trade (Cyprus) Limited v Alfred C. Toepfer International Gmbh [2010] EWCA Civ 1100.
} 
relation to the jurisdiction of the arbitrators or in relation to the exercise of their asserted substantive jurisdiction, and is disappointed by their decision, he can fairly be required to bring proceedings to challenge their award within the limited time applicable to an application under section 67, which in any event may in an appropriate case be extended by the court.

There was no discussion on the issue of participation and consequently, the Court avoided any discussion on how this might affect the status of proceedings or the Court's role.

Conversely, the status of proceedings under English law has had practical impact on parties seeking enforcement in other jurisdictions, where the 1996 Act was the law applicable to the arbitration. In the Judgment of 19 July $2000^{246}$ the Dutch court held that although the party had objected to the arbitrator's jurisdiction, it had lost the right to challenge the substantive jurisdiction under English law. This meant the arbitrators decision on jurisdiction was considered final and could not form a basis for opposing enforcement before the Dutch Courts. ${ }^{247}$

This was essentially the basis of the initial decision in Svenska. ${ }^{248}$ Despite the fact all the English Courts distinguished Svenska, on the basis that the Court of Appeal had agreed the arbitrators had jurisdiction, it warranted further discussion. The Courts' did not engage with issue of finality and delay and whether, if a party such as the Government of Pakistan had participated and if so, what impact that should have on proceedings. It left open the question, and possibility, that a party opposing enforcement could be in a better position before the enforcement court than in an action to annul an award before the court at the seat.

Somewhat ironically in the present case, a limitation on the role of the court at the seat has more similarities with the French theory of arbitration. The French position holds that a court in the jurisdiction where a party wishes to enforce an international arbitral award may decide on its recognition and enforcement in accordance with its own rules, and that the impact of an annulment decision by a national court is limited to its own

\footnotetext{
$\overline{246}$ Judgment of 19 July 2000 XXVI Y.B Comm. Arb 827 (Arronissementreaschtbank Almelo) 2001 in G Born International Arbitration: Cases and Materials (Wolters Kluwer) 2011 Aspen Publishers at 1148.

${ }^{247}$ Judgment of 19 July 2000 XXVI Y.B Comm. Arb 827 (Arronissementreaschtbank Almelo) 2001, in G Born International Arbitration: Cases and Materials (Wolters Kluwer) 2011 Aspen Publishers at 1148.

${ }^{248}$ Svenska Petroleum Exploration AB v Republic of Lithuania [2006] EWCA Civ 1529.
} 
jurisdiction: ${ }^{249}$ While the same outcome may seem to result, the basis and consequence of the English and French decisions are quite distinct. The French theory is rooted very much in a theory of arbitration that sees arbitral awards as rendered through the arbitral process rather than the judicial system. ${ }^{250}$ Conversely the reference in the Supreme Court to the relevance of the English decision in the French courts emphasises the relevance of the judicial role.

\section{No deference to tribunal}

Unlike the courts below ${ }^{251}$ the Supreme Court was the only court to focus the enquiry squarely in the context of competence-competence. However there were subtle, but important distinctions in how the Law Lords conceived of the principle of competencecompetence. Implicit in the approach was the sense that only a court should decide those fundamental matters.

The considerations of Lord Mance, Lord, Saville, and Lord Hope indicate a reserved approach, with greater reflection on traditional English principles towards the supervision of arbitral proceedings. Lord Mance treated the nature of the exercise which an enforcing court should undertake, and the relevance of the fact the tribunal had ruled on its jurisdiction, together. Noting that Dallah's case referred extensively to Fouchard, Gaillard \& Goldman, Lord Mance went on to a further cite those same authorities to the effect that the purpose of the rule is not to leave the question in the hand of arbitrators alone and "their jurisdiction must instead be reviewed by the courts if any action is brought to set aside to enforce the award." 252

\footnotetext{
${ }^{249}$ Société Putrabali Adyamulia v. Société Rena Holding, Cass. 1e civ., June 29, 2007, 2007 Rev. Arb. 507 ("An international arbitral award, which does not belong to any state legal system, is an international decision of justice and its validity must be examined according to the applicable rules of the country where its recognition and enforcement are sought"); Emmanuel Gaillard "The Representations of International Arbitration" (2007) 238 (67) New York Law Journal.

${ }^{250}$ See above n 250, and also Emmanuel Gaillard "International Arbitration as a Transnational System of Justice - The Next Fifty Years”, ICCA Congress Series No. 16, 2012, pp. 66-73.

${ }^{251}$ In the High Court, arguments about the scope of enquiry and deference to the tribunal were dealt with together, Aikens $\mathrm{J}$ deciding the issue purely as one of statutory interpretation. However, the relevance of proceedings that could be taken before the French courts were dealt with in the context of estoppel, based both on the basis of the tribunals decision itself, and on the status of proceedings under French law.

${ }^{252}$ Dallah UKSC above n 1 at [22] per Lord Mance., referring to Gaillard and Savage (ed) Fouchard Gaillard Goldman on International Commercial Arbitration (Kluwer Law International 1999) at 659.
} 
Lord Mance also referred to the 1954 decision of Devlin J in Christopher Brown Ltd v Gennossenschaft Osterreichischer Waldbesitzer Holzwirtschaftsbetriebe ${ }^{253}$ holding that while an arbitral tribunal may make may enquiries "the result of that inquiry has no effect whatsoever upon the rights of the parties." ${ }^{254}$ The nature of the exercise was unaffected by the tribunal's consideration: ${ }^{255}$

The tribunal's own view of its jurisdiction has no legal or evidential value when the issue is whether the tribunal had any legitimate authority in relation it the Government at all.

The Departmental Advisory Committee report was also cited by Lord Saville emphasising that whether arbitrators had jurisdiction is essentially a matter the court must independently determine, as to allow the arbitrators to decide would "...provide a classic case of pulling oneself up by one's own bootstraps. ${ }^{.256}$

Lord Hope's contribution was a brief and rather blunt statement, noting that as a matter that sat at the heart of the proceedings " $[I] t$ must be for the court to determine. It cannot be left to the determination of the arbitrators." ${ }^{257}$ Nor was the exercise affected by a determination by the tribunal, whatever its composition, although the Court may have regard to its reasoning and conclusions. ${ }^{258}$ With any suggestion of 'deference' disposed of the Supreme Court confirmed the place of enforcement must 'independently" determine the matters before it, and act as a court at first instance, unrestricted in the evidence it can hear, and uninfluenced by the fact of a previous arbitral decision or its status. $^{259}$

${ }^{253}$ Christopher Brown Ltd $v$ Gennossenschaft Osterreichischer Waldbesitzer Holzwirtschaftsbetriebe [1954] 1 Q. B. 8.

${ }^{254}$ Above n 12 - 13, cited Dallah UKSC above n 1 at [25] per Lord Mance, and [93] per Lord Collins

${ }^{255}$ Dallah UKSC above n 1 at [30] per Lord Mance.

${ }^{256}$ Dallah UKSC above n 146 at [159].

257 Dallah UKSC above n 1 at [148].

${ }^{258}$ Dallah UKSC above n 1 at [31] per Lord Mance, approving of the position as stated in the Governments written submission. The composition on the tribunal was a point clearly emphasised by Dallah, indicated by Lord Mance's comment "It is also so whatever the composition of the tribunal - a comment made in view of Dallah's repeated (but no more attractive for that) submission that weight should be given to the tribunals "eminence", "high-standing and great experience." at [30].

${ }^{259}$ Dallah UKSC above n 1 at [28] per Lord Mance, [101]-[104] per Lord Collins, [148] per Lord Hope, [160] per Lord Saville. 
Lord Collins was the first, and only judge, to comprehensively review the principles of international commercial arbitration and comparative procedure, concluding that while it was a principle of international commercial arbitration that a tribunal could consider its own jurisdiction: ${ }^{260}$

...it does not follow that the tribunal has the exclusive power to determine its own jurisdiction, nor does it follow that the court of the seat may not determine whether the tribunal has jurisdiction before the tribunal has ruled on it. Nor does it follow that the question of jurisdiction may not be re-examined by the supervisory court of the sear in a challenge to the tribunals ruling on jurisdiction. Still less does it mean that that when the award comes to be enforced in another country, the foreign court may not re-examine the jurisdiction of the tribunal.

Observing the degree of scrutiny, including the factual enquiry would "depend on national law, subject to applicable international conventions" ${ }^{261}$ Lord Collins referred to the position under German and French law, noting the French court in Pyramids case confirmed it was for the court "to examine as a matter of fact all circumstances relevant to the alleged defects...in particular, it is for the court to construe the contract in order to determine itself whether the arbitrator rules in the absence of an Arbitration agreement. ${ }^{262}$

Once determining that the arbitrators could not determine finally their jurisdiction, it seemed to follow that the court must determine it independently, confirming the earlier decisions, that was a rehearing not a review. That does not follow as a matter of logic or necessity. Although a rehearing may be an option appropriate to some cases, it does not need to be the starting point when enforcement is opposed.

To better reflect this, to Lord Collins' statements might reasonably be added the further qualification: Even where the courts function is to decide, it does not follow that the tribunals' findings have no relevance to the nature of the courts task, or that the court must re-visit findings of fact and of law, or that evidence may be called without restriction.

${ }^{260}$ Dallah UKSC above n 1 at [84].

${ }^{261}$ Dallah UKSC above $\mathrm{n} 1$ at [86].

${ }^{262}$ Dallah UKSC above $n 1$ at [89]. 


\section{Fundamental Integrity}

The Supreme Court agreed that the court's function was to decide the question of validity de novo. This was decided as matter of law, not by reference to the specific facts of the case. However given the Court's unequivocal view that the Government was not a party to the arbitration agreement it is difficult not to suspect that this influenced its approach to the scope of enquiry.

For the most part the issue was framed as one of jurisdiction, and ensuring the fundamental integrity of the arbitral process. Lord Collins specifically referred to Article $\mathrm{V}(1)$ of the New York Convention as safeguarding "fundamental rights"263 (discussed further below).

The basis for the Government of Pakistan's opposition to enforcement was that it was not a party to the agreement, (which was therefore not valid under French law). As arbitration is at its core a consensual process, there can be no doubt that the existence of an agreement to arbitrate is essential to the legitimacy of the arbitral process: ${ }^{264}$

Consent is the cornerstone upon which the temple of private dispute resolution has been built - unlike courts, which derive their power from broadly applicable laws, the authority of an arbitral tribunal flows from the specific agreement between the parties.

Establishing the existence of an arbitration agreement goes to the forum for dispute resolution, rather than the substantive rights. Two important consequences result.

The first goes to the nature of consent. The principles governing ordinary contract formation may not be the same as those establishing consent to arbitrate. ${ }^{265}$ In any case consent may be express, implied, or established by operation of law. ${ }^{266}$ Although the

\footnotetext{
${ }^{263}$ Dallah UKSC above $\mathrm{n} 1$ at [102].

${ }^{264}$ Linda R Boyle "Three's Company: Examining the Third-Party Problem Through an Analysis of Bridas S.A.P.I.C v Government of Turkmenistan “(2008) Hous L Rev (45) 261 at 262.

${ }^{265}$ Amokura Kawharu "Arbitral Jurisdiction” (2008) 23 New Zealand Universities Law Review 238 at 244.

266 Jack Graves "Court Litigation over Arbitration Agreements: is it Time for a New Default Rule?" (2012) Scholarly Works, Paper 413, Touro Law Centre $<$ http://digitalcommonstourolaw.edu/scholalryworks/413> at 15 .
} 
suggestion of the freely consenting party as a "legal fiction' overstates the position, ${ }^{267}$ an agreement to arbitrate can bind non signatories other than by the usual consensual theories of agency, assumption, assignment. ${ }^{268}$ Principles of estoppel, alter ego, the group of Companies doctrine or piercing the corporate veil may all be used to find there has been an agreement to arbitrate. Given the predisposition to arbitration exhibited by the international business community, there may be grounds in some cases to argue a presumption in favour of arbitration, while case law - if not academic writings - might suggest the opposite in the context of State Entities. ${ }^{269}$ The parameters of the doctrine, as Lord Collins, noted are one of the more controversial issues in international arbitration. ${ }^{270}$

The second consequence follows from this distinction between forum and substantive rights and means the law applicable to the arbitration agreement, and its validity, will frequently be different from the law which governs the underlying contract. This follows from the principle of separability, and default choice of law provisions within the New York Convention.

In Dallah, the decision of the tribunal had been that the Government of Pakistan was bound by the arbitration agreement, notwithstanding that it was not a signatory. The legal basis for that determination was somewhat fluid. Before the tribunal Dallah appeared to have argued its case on the basis the Government was the alter ego of the MORA. Instead, the decision of the tribunal concluded the Government was a 'true party' to the agreement based on the test of 'common intention' which the Tribunal identified by reference to transnational principles applied to international arbitration under French law. The conclusion also aligned with good faith and the general justice of the case.

\footnotetext{
${ }^{267}$ Jack Graves above note ("In short, real consent arguably ceased to be the touchstone of arbitration law some time ago") and citing at 16 Karim Youssef "Consent in Context: Fulfilling the Promise of International Arbitration" (2009) 8.

${ }^{268}$ Gary Born International Commercial Arbitration above n 16 at 1142.

${ }^{269}$ G Born International Commercial Arbitration above n 16 at 1202. In the Pyramid case the Paris Court d'Appel annulled an award of a tribunal holding the Ministry of Tourism was not a party despite signing the contractual terms under the words "approved, agreed and ratified." Similarly, the decision in ICC Case No. 8035, 124 J.D.I. (Clunet) 1040 (1997) involved an investor dispute with Libya, where the State as executed a suspension agreement saying it was "Approved and endorsed." Born says "these decisions reflect an unsatisfactory view of the manner in which regulatory authorities exercise their powers. They also risk producing unfair fact finding and legal decision by absenting what is often a key party from the dispute resolution process."

${ }^{270}$ Dallah UKSC above n 1 at [105] per Lord Collins.
} 
French law, and the French legal test, was only relevant to determining the existence of an arbitration agreement. While concepts such as good faith may also operate in commercial context, it is difficult to see how any principles of French law could have applied to the substance of the dispute. However the manner in which the tribunal framed its conclusion and subsequent award on the merits against the Government suggest it may have.

The practical concern of the English courts may have been that the legal basis on which the Government may have agreed to arbitrate became conflated with the law governing the substantive obligation. This may be inferred from the statement of Rix LJ in the Court of Appeal who, expressly referring to the underlying contract, said "There can hardly be a more fundamental defect than an award against someone who was never a party to the relevant contract or agreement to arbitrate. ${ }^{271}$

This suggests that the real issue underlying the approach for de novo review lay in the Court's discomfort on the basis on which the Government was held to be a party on the particular facts. Once the English court decided the scope of the enquiry, the Court was then able to determine the applicable law and its content, and apply it to the relevant facts, without restriction.

The Supreme Court's approach to deciding the Government was not a party to the arbitration agreement is discussed in the next section. The approach of the English court demonstrates how domestic laws can inevitably colour the court's assessment of these matters. $^{272}$

However in the context of the decision that the enforcement court was to decide the matter by way of re-hearing, the reasoning of the Court is not compelling. It answered the question of the scope of enquiry purely as matter of law, but avoided engaging with fundamental principles relevant to interpretation of the Convention. This was compounded by the Court looking to domestic law principles to justify its conclusions. In rejecting Dallah's core arguments out of hand, it conflated the question of the court's function with how it should fulfil it, and failed to justify why its conclusions led inexorably to a rehearing, rather than a more nuanced approach. Overall, the Court avoided engaging with the complexities that exist in the intersect between courts and

\footnotetext{
${ }^{271}$ Dallah CA above n 10 at [87].

${ }^{272}$ Thomas E Carbonneau, "The Exercise of Contract Freedom in the Making of Arbitration Agreements," Vand. J. Trannat'l Law (2003) 36 1189, at 1206.
} 
arbitral proceedings, which were only compounded when proceedings engaged the likelihood of double control. 


\section{$V$ The Existence (or not) of an Agreement to Arbitrate}

There are distinct differences in the legal cultures of England and France, and it has been observed that the Dallah saga speaks volumes as to these. For example, although good faith provides the foundation of civil law systems it had only a brief appearance in English commercial law before "the commercial and mercantile law of England developed in a different direction preferring the benefits of simplicity and certainty which flow from requiring those engaging in commerce to look after their own interests." 273 Similarly, the distinct differences in contract matters has been noted in other contexts like proceedings under the $\mathrm{CSIG}^{274}$ which the English courts have noted "reflect[ed] the French philosophy of contractual interpretation, which is altogether different from that of English law." 275

Although before the Supreme Court both parties appeared to accept that, "transnational law is part of French law (as Dallah had submitted), the reference to these transnational principles meant that part of that enquiry before the English Court was not whether French law had been applied correctly "but whether the tribunal had applied French law at all.,276

Somewhat ironically, one criticism of the English court is although it purported to apply French law to the facts before it, it failed to apply that French law in substance. ${ }^{277}$ The approach suggests the Court placed more importance on the need for commercial predictability rather than the finality of arbitral awards. ${ }^{278}$

\footnotetext{
$\overline{273}$ Manifest Shipping Co Ltd v Uni Polaris Insurance Co Ltd [2003] 1 AC 469 at [45] per Lord Hobhouse.

${ }^{274}$ United Nations Convention on Contracts for the International Sale of Goods (opened for signature 11 April 1980, entered into force January 1988).

${ }^{275}$ Chartbrook Ltd $v$ Persimmon Homes Ltd [2009] UKHL 38 at [39] per Lord Hoffman.

${ }^{276}$ Dallah UKSC above n 1 at [72].

277 Gary Born "Dallah and the New York Convention" (7 April 2011) Kluwer Arbitration Blog $<$ www.kluwerarbitrationblog.com. $>$.

${ }^{278}$ Gary Born International Commercial Arbitration above n 16 at 1206.
} 


\section{A Deciding the applicable law}

Notwithstanding the earlier position before the tribunal, both parties agreed in the High Court that any question of validity had to be determined by reference to French law. ${ }^{279}$

The objective under French law was to find the common will of the parties, which Aikens $\mathrm{J}$ (at first instance) identified as requiring him to decide whether the Government was "implicated in the performance of the contract" and if it accepted the terms of the arbitration clause. ${ }^{280}$ This required demonstrating an awareness and existence of the scope of the arbitration clause. The French law experts agreed that French law would take into account the requirements of good faith ${ }^{281}$ and described the principle of transnational law in French law: ${ }^{282}$

Under French law, the existence, validity and effectiveness of an arbitration agreement in an international arbitration need not be assessed on the basis of national law, be it the law applicable to the main contract or any other law, and can be determined according to rules of transnational law. To this extent it is open to an international arbitral tribunal, the seat of which is in Paris to find that the arbitration agreement is governed by transnational law.

As the French test was agreed to be a broad factual enquiry it would include both the relevance of the MORA as a State entity and relevant issues of Pakistan law. ${ }^{283}$ Although the content of that law was agreed and identified by the French experts and not in dispute between the parties, Lord Mance could not resist the comment: ${ }^{284}$

it is difficult to conceive that any more relaxed a test would be consistent with justice and reasonable commercial expectations, however international or transnational the arbitration or transnational the principles applied.

\footnotetext{
${ }^{279}$ Where Dallah and the Government of Pakistan argued respectively, for the application of Saudi Arabian and Pakistani law on the basis that these were the systems of law the contract had the closet connection with see above $\mathrm{n} 121$

${ }^{280}$ Dallah $H C$ above $n 9$ at [89]

${ }^{281}$ Dallah $H C$ above $n 9$ at [90]

${ }^{282}$ Dallah $H C$ above $n 9$ at [92]

${ }^{283}$ Dallah $H C$ above $n 9$ at [97]. After conflicting evidence in whether the law referring to contracts being in the name of the President was mandatory or directory, Aikens J determined this was only one factor that would be taken into account so he did not need to decide the point - but indicated it would be a powerful factor against a common intention supra [103].

${ }^{284}$ Dallah UKSC above n 1 at [18] per Lord Mance.
} 
This foreshadowed the emphasis on English principles such as privity of contract in the Courts assessment of the facts and their subsequent application, as much as the lack of English appreciation for concepts such as good faith. The English Court gave greater weight to the form of the Agreement itself, particularly the changes from the content of the Memorandum of Understanding, and specifically the shift in the named parties from the Ministry of Religious Affairs, Government of Pakistan to the Trust.

\section{B Applying the law - "same same but different?"}

The tribunal, the English Courts and the French Court identified the same relevant events, though the assessment and significance of those events differed. The relevant events for present purposes can be summarised as relating to the following: the creation of the Trust, the Memorandum of Understanding, the Agreement, performance of the Agreement, the lapsing of the Ordinance establishing the Trust, the termination letter of 19 January 1997 , the two sets of Pakistani court proceedings (the first initiated by the Trust and the second initiated by the Government), and the letter of 5 June 1998 from the Government to the ICC.

Both the Tribunal and the French Court gave weight to what happened before and after the Agreement, as well as the fact the Government exercised a degree of control over the Trust and was involved in the performance of the Agreement.

On review, all of the matters relied on by the tribunal were dismissed by both Lord Mance and Lord Collins, the latter saying "none of these matters could possible justify a finding there was common intention that the Government should be bound by the arbitration clause". ${ }^{285}$ Lord Mance was somewhat more brutal. Lord Mance rejected the tribunals' analysis of the facts, rejected its determination and application of the law and said its "contrary reasoning is neither conclusive nor on examination persuasive in a contrary sense.",286

The Supreme Court emphasised the separate legal personality of the Trust. ${ }^{287}$ The Government's involvement in negotiations did not affect the position in the face of a

${ }^{285}$ Dallah UKSC above $\mathrm{n} 1$ at [142] per Lord Collins.

${ }^{286}$ Dallah UKSC above $\mathrm{n} 1$ at [66].

${ }^{287}$ Dallah UKSC above n 1 at [43], [134], [135]. 
clear and deliberate change to the structure of the Agreement, and involvement of officials in performance of the Agreement could not amount to a subjective intention for the Government to be bound. ${ }^{288}$

The English courts also came to a different view on the significance of the termination letter, holding that the reference to Secretary must have been Secretary of the Trust rather than MORA, and did not consider the manner in which the court proceedings were instigated supported a contrary conclusion.

Both Lord Mance and Lord Collins appeared strongly influenced by the fact Dallah was advised by lawyers in its transactions ${ }^{289}$ and the clear change in the legal structure. The only 'serious contraindication' related to the terminating letter and the court proceedings instigated by the MORA. Neither was sufficient to find common intention. ${ }^{290}$ This strong sense of English contract theory was evident in the criticism the Court reserved for the tribunal and its focus on the broader conduct of the Government, rather than the legal structure of the arrangement.

When assessing the test to be applied, the Supreme Court referred to the decision of the Paris Cour d'Appel in Orri $^{291}$ where the Court said; ${ }^{292}$

According to the customary practices of international trade, the arbitration clause inserted into an international contract has its own validity and effectiveness which require that its application be extended to the parties directly involved in the performance of the contract and any disputes which may result therefrom, provided that it is established that their contractual situation, their activities and the normal commercial relations existing between the parties allow it to be presumed that they have accepted the arbitration clause of which they knew the existence and scope, even though they were not signatories of the contract containing it. (Emphasis added.)

\footnotetext{
${ }^{288}$ Dallah HC above $\mathrm{n} 9$ at [114], Dallah UKSC above $\mathrm{n} 1$ at [45].

289 "It must go without saying that the firm well understood the difference between agreement with a state entity, on the one hand, and the State itself on the other." Dallah UKSC above n 1 [133] per Lord Collins. See also para [43] per Lord Mance.

${ }^{290}$ Dallah UKSC above n 1 at [138] - [142] per Lord Collins.

${ }^{291}$ Orri v Societe des Lubrifiants Elf Aquitaine [1992] Jur Fr 95 (11 January 1990).

${ }^{292}$ Orri v Societe des Lubrifiants Elf Aquitaine [1992] Jur Fr 95 (11 January 1990), referred Dallah UKSC above $\mathrm{n} 1$ at [18], see also Jacob Grierson and Dr Mireille Taok "Dallah: Conflicting Judgments from the U.K Supreme Court and the Paris Cour d'Appel” (2011) 28 J. Int Arb 3407 - 422 at 417.
} 
Notwithstanding Lord Mance's view of the already "relaxed" nature of the test to be met, both Lord Mance and Lord Collins considered the principles adopted by the Tribunal were "too general' to properly reflect French law and applied in manner that represented too low a threshold. ${ }^{293}$ The ability for parties to structure their commercial dealings in certain ways and to have the integrity of those structures respected was foremost at the mind of Lord Mance. The result of the test, as applied by the tribunal, would be a presumption that many third parties were parties to a contract deliberately structured otherwise. ${ }^{294}$

However, when the case went before the Paris Court of Appeal, much like the tribunal before it, the events were viewed in their totality. This is clear from the concluding statement of the Paris Court: ${ }^{295}$

[T]his involvement of the Government of the Republic, Ministry of Religious Affairs, in the absence of acts alleged to have been accomplished by the Trust, as well its behaviors during the pre-contractual negotiations, confirm that the Government of Pakistan, Ministry of Religious Affairs........ behaved as the true Pakistani party during the economic transaction.

In their review of the conflicting court decisions, Jacob Grierson and Dr Mireille Taok ${ }^{296}$ attribute the differing perspectives to two main reasons. First, that the factual findings of the Supreme Court differed from the Paris Court d'Appel on matters such as whether the termination letter was signed by Mr Mufti in his capacity as Secretary of the MORA or of the Trust and second, the relevance of the Government's involvement in negotiations to the test of common intention. ${ }^{297}$

\footnotetext{
${ }^{293}$ Dallah UKSC above n 1at [40] per Lord Mance, [140] per Lord Collins.

${ }^{294}$ Dallah UKSC above n 1 at [40] per Lord Mance.

${ }^{295}$ Cour d'appel Paris February 17, 2011, Translation by the authors Jacob Grierson and Dr Mireille Taok above n 294 at 414 fn 26. The original French text reads : "[C]ette implication du Gouvernement de la République, Ministère des Affaires Religieuses, sans qu'il soit fait état d'actes accompli par le Trust, comme son comportement lors des négociations pré-contractuelles confirment que la création du Trust était purement formelle, et que le Gouvernement du Pakistan, Ministère des Affaires Religieuses comme Dallah en convenait s'est comporte comme la véritable parties pakistanaise lors de l'opération économique."

${ }^{296}$ Jacob Grierson and Dr Mireille Taok "Dallah: Conflicting Judgments from the U.K Supreme Court and the Paris Cour d'Appel” (2011) 28 J. Int Arb 3407 at 417.

${ }^{297}$ Above n 298 at 417.
} 
On 27 March 2007, just prior to the decision of the English High Court in Dallah, the Cour d'Cassation delivered its judgment in $A B S^{298}$ where it held "the effects of an international arbitration clause extend to parties directly involved in the performance of the agreement and any disputes arising from it. ${ }^{, 299}$ Unlike Dalico or Orri the Court here seems to equate involvement with common intention and made no reference to acceptance, presumed or otherwise. ${ }^{300}$

The French Court in Dallah seems to have followed this earlier approach. Grierson and Taok note this decision appears to represent an evolution in French case law insofar as it focuses primarily on involvement, without even an indirect reference to the common intention test referred to in later decisions such as $\mathrm{Suba}^{301}$ and $\mathrm{Abela}^{302}$ In those latter cases the court was prepared to find non signatories to be a party in circumstances where they "[C]ould not credibly claim to be unaware of the arbitration agreement" ${ }^{303}$ and where they: ${ }^{304}$

[A]cted as the true shareholders [and therefore could not] legitimately claim to be strangers to the arbitration agreement, whose content they could not be unaware of and which they had implicitly accepted considering their involvement in the operation of the AAA.

On the one hand, given that the Paris Cour d'Appel may well be presumed to know French law better than an English court, it is difficult not to imagine some validity in the criticism that the English courts failed to apply the law in substance. However in some respect, criticism of the UK Courts may be considered a little unfair, as on closer inspection it appears the Courts were not quite applying the same facts to the same law.

${ }^{298}$ ABS, Cass. 1e civ., March 27, 2007, 2007 Rev. Arb. 788.

${ }^{299}$ ABS, Cass. 1e civ., March 27, 2007, 2007 Rev. Arb. 788 note J.El Ahdab: 134 J. Driot Int'l (Clunet) 968 (2007), note C. Legros: Cahiers de l'arbitrage 6 (no. 3, 2007), note François-Xavier Train as translated by the authors Jacob Grierson and Dr Mireille Taok above n 298at 418.

${ }^{300}$ Grierson and Taok above n 298 at 417, G Born International Commercial Arbitration above n 16 at 1205 $-1206$.

${ }^{301}$ Suba, Cass, 1e civ., May 7 2009, petites Affiches 10 (No. 159-160, 2009), note Jerome Narbet (G\&T translation as translated by the authors Jacob Grierson and Dr Mireille Taok above $\mathrm{n} 298$ at 418.

${ }^{302}$ Abela, Cass. 1e civ., October 6, 2010, 2010 Rev. Arb 813, note François-Xavier Train.

${ }^{303}$ Suba above n 293, translated by the authors Jacob Grierson and Dr Mireille Taok).Grierson and Taok above $\mathrm{n} 298$ at 418 .

${ }^{304}$ Abela above $\mathrm{n} 298$ translated by the authors Jacob Grierson and Dr Mireille Taok above $\mathrm{n} 288$ at 418 . 
Despite his trenchant criticism of the decision, Gary Born agrees that, without something more, merely being implicated or aware of an arbitration clause should not be sufficient to bind a party. The touchstone, in his view, is whether the parties intended that the nonsignatory be bound by and benefit from the arbitration clause. ${ }^{305}$

In the context of Dallah perhaps there was something more. The majority of the tribunal were influenced by the general justice of the case, The FPA records that Dr Shah and Lord Mustill were reassured "the more so given the background of the Memorandum of Understanding in which the participation of the State was not in doubt." 306 None of the English Court decisions included that part of the award, despite quoting the preceding paragraph. ${ }^{307}$ Lord Collins did expressly note that the very existence of the Trust was at the control of the Government, and at least one academic has suggested the tribunal (and Dallah) based its jurisdiction arguments on the wrong arbitration agreement. ${ }^{308}$

This may be attributed in part to the threshold for consent. French law expressly distinguishes the test when assessing agreement to arbitrate. This may be seen as giving effect to, or extending the principle of separability from the underlying contract.

In contrast, it was implicit in the Supreme Court decision that the standards to be met when determining consent to arbitration are the as same for general contractual principles, albeit to an English standard.

In effect, the English courts have confirmed that a party will not be able to enforce against a non-signatory in the United Kingdom, on anything less than consent determined by reference to the usual English contractual or legal notions by which a party may be bound. The English courts may be seen to have intervened because as far as competing policies go, certainty of the commercial expectation of parties has priority over the finality of arbitral awards. That is not a new development. The English legislature and court have frequently intervened in a manner that served the wider interests of the United

\footnotetext{
${ }_{305}$ G Born International Commercial Arbitration above n 16 at 1206.

${ }^{306}$ Jan Kleinheisterkamp "Lord Mustill and the Courts of Tennis - Dallah v Pakistan, in England, France and Utopia” (2012) Modern Law Review 75 (4) 606 - 654 at 653, citing ICC Case No 9987, Partial Award on Jurisdiction of 26 June 2011 International Journal of Arab Arbitration [2010/2] 337 at 365-366.

${ }^{307}$ Jan Kleinheisterkamp "above n 308 at 653 fn 60.

${ }^{308}$ Jan Kleinheisterkamp above n 308 at 653, citing ICC Case No 9987, Partial Award on Jurisdiction of 26 June 2011 International Journal of Arab Arbitration [2010/2] 337 at 365-366.
} 
Kingdom generally, and London more specifically, as an important centre for commercial trade. $^{309}$

This demonstrates until there is an agreed international test to be applied, domestic laws will inevitably colour the courts assessment of these matter. ${ }^{310}$ In turn, this lead to the very result the arbitration framework seeks to avoid. National courts intervening in the arbitral process and applying domestic standards to international cases.

Where a fundamental domestic principle is involved, and where there are competing principles Dallah may influence courts in other cases to strive for 'the right result'. Such an approach has the potential to undermine the finality and enforceability of arbitral awards as well as the goal of uniform approach to treatment of arbitral awards.

\section{Burden of proof}

One of Born's criticisms of the decision in Dallah is the Supreme Court misunderstood the meaning and purpose of Article $\mathrm{V}$ and the burden of proof under the Convention. ${ }^{311}$

The conclusions of the Supreme Court were consistently framed in the context that the manner that the material before the court did not "justify" the tribunal's conclusions which Born interprets as the court requiring Dallah or prove the existence of the valid arbitration agreement, rather than recognising the onus on the Government to disprove it. ${ }^{312}$ Although other commentators have disagreed that the Court failed to recognise the onus, the proceedings do raise the question of what the onus means in practice. ${ }^{313}$

\footnotetext{
${ }^{309}$ It was when the combined effect of the decision in Vyniors Case and the Statute of Fines and Penalties of 1697 (An Act for the better Preventing Frivolous and Vexatious Suits) which prohibited recovery of penalty sums had an unintended effect on arbitration appears unintended, that the English legislature intervened and passed a statute with the stated object of rendering the awards of arbitrators more effectual in all cases. Likewise, the advent of the Arbitration Act 1979 (the precursor to the 1996 legislation) was wholly attributable to a desire to protect and promote London as a seat of international arbitration, Lord Hacking "The Story of the Arbitration Act 1979" (2010) 76 Arbitration 125 at 128.

310 Thomas E Carbonneau, "The Exercise of Contract Freedom in the Making of Arbitration Agreements, (2003) Vand. J. Trannat'l L 36 1189, 1206.

311 Gary Born "Dallah and the New York Convention" (7 April 2011) Kluwer Arbitration Blog $<$ www.kluwerarbitrationblog.com>.

${ }^{312}$ Born above n 313.

${ }^{313}$ Jan Kleinheisterkamp above n 308 at 645.
} 
This was the subject of discussion in Altain Khuder, where interpreting the Convention in accordance with its pro enforcement approach, Croft J accepted that "clear, cogent and strict proof" of the grounds for opposing enforcement was required. ${ }^{314}$

Ultimately, on appeal, the Court of Appeal, differed on the standard of proof required. ${ }^{315}$ The majority $(2-1)$ held the section did not require anything other than a standard assessed on the balance of probabilities. ${ }^{316}$ However the Chief Justice, Warren CJ, differed from both the approach taken by Croft $J$ in the Supreme Court and the view of the majority. The Chief Justice agreed the onus on an award debtor to prove one of the specifying grounds was a "heavy onus" though considered the "cogency required to discharge it depended on the issue to be proved." 317

Despite the majority of the Court of Appeal in Altain Khuter effectively reaching the same view on the nature of the burden of proof as the English courts, this was dicta, and the issue may not be fully resolved. The fact a specialist arbitration Judge and the Chief Justice of the Court of Appeal of Australia held a different view, indicate the matter is far from obvious, and perhaps fully settled. Of course, even the approach to interpretation may not lead to expected results. The Court of Appeal in Altain Khuder ultimately held in that case, there was a threshold burden to be met by the award creditor to establish the existence of the arbitration agreement. ${ }^{318}$ Although the practical outcome may be fact dependant, given the unusual facts of the case, ${ }^{319}$ it demonstrates the relevance of the burden of proof. It is a substantive burden and therefore who bears it becomes relevant, the fundamental difference being the threshold is required to determine whether the Convention standards apply. Once they do, the usual principles to application of the Convention become relevant.

In either case, the Australian debate represents the better approach to interpretation. Legislation incorporating the New York Convention was firmly placed in its international

\footnotetext{
${ }^{314}$ Altain Khuder LLC v IMC Mining \& IMC Mining Solutions [2011] VSC 1 at [64].

${ }^{315}$ IMC Aviation Solutions Pty Ltd v Altain Khuder LLC [2011] VSCA 248.

${ }^{316}$ Above $\mathrm{n} 317$ at [192].

${ }^{317}$ Above n 317 at [52], [53].

${ }^{318}$ Above $n 317$ at [46] per Warren CJ and [146] per Hansen JA and Kyrou JA.

319 The award was worded not in the senses that the part opposing recognition was party to the agreement(though that was implied in the written award) but instead said the "Second Defendant is liable to pay, for and on behalf of the First Defendant, the amount of US\$5,903,098.20 plus the arbitration fee amount of US\$50,257.70 to the Plaintiff.." Altain Khuder LLC v IMC Mining \& IMC Mining Solutions [2011] VSC 1.
} 
context and determined by reference to the purpose and principles of the Convention. Conversely, the English court did not to pause to even consider the prospect that the purpose of the Convention might have any bearing on the construction of the words used.

Defining the burden of proof by reference to English civil proceedings was clearly wrong. ${ }^{320}$ That imports without question a civil domestic law standard to an international convention, and is at odds with the approach taken to other provisions in the New York Convention.

A notable example is the public policy exception to recognition and enforcement at Article V (2) (b) of the New York Convention, which provides a court may refuse recognition or enforcement of an arbitral award where "it would be contrary to the public policy of that country."

The language of the Convention cannot be read as requiring the application of purely international public policy. ${ }^{321}$ However there is general - but not universal - agreement that while any State can themselves determine, the content of its public policy considerations, the objectives of the Convention are best met when those public policy exceptions are determined consistently with international public policy matters, rather than purely domestic sources. ${ }^{322}$

Conversely, the Court's focus here, on an independent determination, has more similarity to the provision of Article V (2) of the Convention which enables the court "to find" that one of the two thresholds has been met. The notion of an independent inquiry is something quite different to a burden of proof resting on a party opposing enforcement, the latter suggesting a substantive burden of persuasion. ${ }^{323}$ It subtly, but significantly,

\footnotetext{
$\overline{320}$ Dallah $H C$ above $\mathrm{n} 9$ at [82] a point left undisturbed by the Supreme Court.

${ }^{321} \mathrm{G}$ Born International Commercial Arbitration above $\mathrm{n} X$ at 2837, noting the language of the New York Convention clearly says 'contrary to the public policy of that country.'

${ }^{322}$ G Born International Commercial Arbitration above n X at 2833, 2844 referring within to differing academic view: Mayer \& Sheppard, "Final ILA Report on Public Policy as A Bar to enforcement of International Arbitral Awards" (2003) Arb. Int'1 19249 at 250 and Paulsson "The New York Convention in International Practice - Problems of Assimilation" in The New York Convention of 1958 100, 113 (ASA Special Series No. 9 1996) cf R Merkin Arbitration Law (2004, 2007) at 19.58; A Redfern \& M Hunter (eds) Law and Practice of International Commercial Arbitration ( $4^{\text {th }}$ ed, Sweet \& Maxwell, London, 2004) at 10.52 .

${ }^{323}$ Gary Born "Dallah and the New York Convention" (7 April 2011) Kluwer Arbitration Blog $<$ www.kluwerarbitrationblog.com.>.
} 
changes the nature of the enquiry. This is all the more pronounced when any presumptions as to the finding of the arbitral tribunal are ignored. In practice the approach of the Supreme Court arguably doesn't appear to amount to more than a procedural allocation of pleading roles, or in practice, differ greatly from the threshold test decided in Altain Khuder. 


\section{Alternatives to de novo review}

The starting point for the English High Court was de novo review. It then re-heard the matter entirely, before deciding the tribunal got the question of whether the Government was a party to the arbitration agreement wrong. Article V of the New York Convention does not allow enforcement to be refused where the arbitral tribunal got the law wrong, nor does it expressly provide for a review of the merits of a tribunals decision. Determining whether any of the grounds have been established clearly requires a judicial decision. Although the Supreme Court affirmed the decisions of the lower courts, holding the decision must be made de novo, this Part argues that a more nuanced test can and should be developed for when the validity of the arbitration agreement is challenged under article V(1)(a) New York Convention.

The analysis below first briefly highlights the nature of mandatory de novo review, demonstrating the pathological consequences that may result. It then considers the alternative options for making judicial decisions and the policy considerations that often determine the appropriate approach. The merits of each are weighed against the context of the objectives of international commercial arbitration, before an alternative test to when enforcement proceedings are opposed under article V (1) (a) of the New York Convention is identified. Finally, the facts of Dallah are considered against a more nuanced approach, suggesting the same outcome could have been reached on a more convincing basis.

\section{A A Pathological Result?}

The decision in Dallah was cast in very broad and general terms. In the Supreme Court Lord Mance considered the issue before the Court required "ordinary judicial determination" 324 while Lord Collins confirmed that an English court was: ${ }^{325}$

entitled (and indeed bound) to re visit the question of the tribunal's decision on jurisdiction when validity of the arbitration agreement is challenged.

Each member of the Supreme Court, although expressing it in slightly different ways, accepted the issue was to be decided by way of an independent investigation, unlimited in the scope of review or restricted by the tribunal's findings on the facts or the law. This

${ }^{324}$ Dallah UKSC above n 1 at [28] per Lord Mance.

${ }^{325}$ Dallah UKSC above n 1 at [104] per Lord Collins. 
approach went beyond what was necessary to address the Court's focus on initial consent, and leads to a serious prospect of pathological outcomes resulting from any opposition to enforcement under article V(1) of the New York Convention.

At its most broad, the decision in Dallah could support the view that whenever enforcement is opposed under Article V(1), the court is bound to conduct a rehearing, irrespective of the particular grounds relied on. This stems from the emphasis in the lower courts particularly, but certainly supported by the Supreme Court, that the ordinary statutory language of the Convention leads to such a result. In addition to Lord Mance's reference to "ordinary judicial determination", Lord Collins referred to the "plain language of article V (1) (a) as incorporated by s 103(2) (b)." ${ }^{326}$ Both endorsed the decisions of the lower courts that treated the question of the court's task largely as one of statutory interpretation, relying largely on the words "only if that party furnishes.....proof that." 327

On this reasoning, there would be no basis to distinguish how a court should approach its task when determining whether any of those grounds at article V (1) (a)-(e) had been established. The chapeau to article V (1) applies to all grounds under article V (1) (a)-(e). Lord Collins seems to suggest this is the intended result both with his comment that Article V safeguards fundamental rights and the reference to May LJ's statement in Kaniroa $v$ Guinness ${ }^{328}$ that the matters under s 103(2) go to "the fundamental structural integrity of the arbitration proceedings. ${ }^{, 329}$ Lord Collins was clearly referencing article V as a whole, and not limiting the issue to initial consent, evidenced by his further reference to van den Berg: ${ }^{330}$

In fact, the grounds for refusal of enforcement are restricted to causes which may be considered serious defects in the arbitration and award: the invalidity of the arbitration agreement, the violation of due process, the award extra or ultra petitia, the irregularity in the composition of the arbitral tribunal or the arbitral procedure, the non-binding force of the award, the setting aside of the award in the country of origin and the violation of public policy.

\footnotetext{
${ }^{326}$ Dallah UKSC above n 1 at [101] per Lord Collins.

327 Refer infra at Part IV, A 1.

${ }^{328}$ Kanoria v Guinness [2006] 1 Lloyd's Rep, 701.

${ }^{329}$ Kanoria v Guinness [2006] 1 Lloyd's Rep, 701 at 706 per May LJ.

${ }^{330}$ A. van den Berg The New York Arbitration Convention of 1958 (1981) at 265, cited Dallah UKSC above n 1at [102] per Lord Collins.
} 
This requires some pause. De novo review was the starting point for the English courts, not a point it ended up to as a consequence of the specific facts or the subject matter of the challenge before it. The consequences of a rehearing were pointed out by Morison $\mathrm{J}$ in Tajik Aluminium. ${ }^{331}$ The power to challenge the facts must mean that all relevant evidence can be adduced: Case management powers can't be used to exclude otherwise admissible evidence. ${ }^{332}$ The Supreme Court did not disturb the position as stated by Aikens $\mathrm{J}$ in the High Court, where he said "Thus a party must be able to adduce all evidence necessary to satisfy the burden of proof." $" 333$

These evidential matters are important. Although the English courts referred to the practice of the French Courts under the French Civil Code, in practice those courts do not hear evidence. ${ }^{334}$ In contrast, a rehearing under English law is almost like a first instance hearing, subject only to the shifting of the burden of proof. On this reading of Dallah, such a result would follow whenever enforcement was opposed, with parties free to call all and any relevant evidence, thereby extending both the timing and cost of proceedings significantly. This, inevitably, could be followed by subsequent appeals through national courts.

Even limiting the rule from Dallah to Article (V) (1) (a) may lead to perverse results. Although the issue of initial consent was fundamental to the English court, the concept of validity under the New York Convention has a broad aspect. ${ }^{335}$ Validity includes issues of both formal and substantive validity and can encompass allegations of duress, illegality and fraud, which have been the subject of robust approaches by the courts in arbitration proceedings. This focus on the subject matter of the dispute suggests the justification for a rehearing lies more in the basis for opposing enforcement than the text of the Convention and legislation.

\footnotetext{
${ }_{331}^{31}$ Tajik Aluminium Plant v Hydro Aluminium AS [2006] EWHC 1135 (Comm), at [38].

${ }^{332}$ Tajik Aluminium Plant v Hydro Aluminium AS [2006] EWHC 1135 (Comm) Tajik at [44].

${ }^{333}$ Dallah $H C$ above $n 9$ at [83].

${ }^{334}$ Elie Kleiman \& Julie Spinelli "Dallah" One Test, Two Different Findings" (30 June 2011) International law Office $<$ www.internationallawoffice.com. $>$

${ }^{335}$ Stefan Kroll "The Arbitration Agreement in Enforcement Proceedings of Foreign Awards" in S. Kroll, L.A. Mistelis, P. Perales Viscasillas \& V. Rogers (eds), Liber Amicorum Eric Bergsten, International Arbitration and International Commercial law: Synergy, Convergence and Evolution, (Kluwer Law International, Great Britain, 2011) 317.
} 
In either case, although it is generally accepted the grounds under Article V (1) (a) should be construed narrowly, ${ }^{336}$ on its face the Supreme Court approach does not provide for any distinction where enforcement is opposed on grounds that a party may otherwise have been assumed to waive under the applicable law, or where matters going to jurisdictional objections are raised for the first time at the enforcement stage. An 'independent and fresh evaluation of the issues would follow irrespective of the nature of the challenge, or the cogency of the issues raised. ${ }^{337}$ Re-visiting the arbitrator's decisions on the law and the facts is the starting point for consideration, rather than any consideration as to whether a rehearing is an appropriate on the facts, or any presumption of validity or enquiry as to whether the arbitrator decision should be substituted.

There is little "pro arbitration" or "pro enforcement" about this result. It invites wholesale re-litigation on any alleged defect of arbitral procedure through national courts. If adopted broadly, in the absence of internationally agreed standards of the preclusive effect of other courts decisions in enforcement proceedings, it also invites re-litigation in multiple jurisdictions. As Gary Born observes, the New York Convention can never have intended different national courts relitigating the same questions years after the decision of the arbitral tribunal, and many more years after the events that gave rise to the dispute. ${ }^{338}$

That is not an outcome that serves one stop adjudication and finality of litigation, let alone the avoidance of national court systems. Moreover, it renders largely redundant, the objectives of the international arbitration legal framework as a whole leading to a result contrary to: ${ }^{339}$

\footnotetext{
${ }^{336}$ ICCA Handbook above $\mathrm{n} 46$ at Ch III.4 "Bearing in mind the purpose of the Convention... its drafters intended that the grounds for opposing recognition and enforcement of Convention awards should be interpreted and applied narrowly and that refusal should be granted in serious cases only; China Minmetals Materials Import and Export Co. Ltd v Chi Mei Corporation 334 F3d 274, 288 (2003) "Consistent with the policy favouring enforcement of foreign arbitration awards courts have limited defenses to the defense set out in Article V of the New York Convention and generally have construed those exceptions narrowly."

${ }^{337}$ The words recently used to express the test under s 67 Arbitration Act 1996 (the analogous provision under English law - according to the Supreme Court) in Beijing Jianlong Heavy Industry Group v Golden Ocean Group Ltd \& Ors [2013] EWHC 1063 (Comm).

${ }^{338}$ Gary Born "Dallah and the New York Convention" (7April2011) Kluwer Arbitration Blog $<$ www.kluwerarbitrationblog.com>.

${ }^{339}$ Paul Tan, "Competing priorities in international commercial arbitration" Int'l Arbitration Law Rev. (2011). 67- 68, 70.
} 
the finality of arbitral awards, and the procedural economy and efficiency that arbitration is supposed to provide... [As a consequence] [d] e novo review at the enforcing stage takes back on the one hand what the doctrine of competencecompetence had purported to give with the other.

In practice, there seem very little to distinguish this approach from that which would unfold where the New York Convention was not engaged at all. ${ }^{340}$ The grounds on which enforcement may be opposed are respected, meaning the New York Convention itself cannot be said to be entirely redundant. However, it is arguably ineffective in achieving its intended objectives where the burden of proof is treated merely as an allocation of pleading roles and the court focuses its energy on an independent enquiry. ${ }^{341}$

However, a rehearing was not the only option open to the Court. In this respect, the reference to "ordinary judicial determination" ${ }^{442}$ by Lord Mance is somewhat mischievous, insofar as it suggests there is only one way to make a decision. There were alternative ways the Court could fulfil its task to determine whether the grounds at article V (1) (a) New York Convention's 103 (2) (b) Arbitration Act 1996 had been made out.

\section{B The options for judicial decisions}

The text of the Convention leaves a wide discretion to a court in how to interpret and apply its provisions, and Lord Mance's statement belies the many ways judicial decisions may be made under English law. In addition to Dallah's argument for a limited review, and a high degree of deference, circumstances may lead a court to distinguish its approach to the law and the facts, introduce thresholds for intervention or for the hearing of evidence. The approach generally differs between first instance hearings and subsequent challenge.

Generally speaking, at first instance, whether before a tribunal or court, evidence will be heard directly, witnesses may be called, and a decision will be made based on the determination of facts, inferences drawn from them, interpretation of the law, and the

\footnotetext{
${ }^{340}$ For example, the position that would have resulted if a "pre-condition" was inserted as a gateway question to the New York Convention - as in Altain Khuder or as hinted at by Lord Mance in Dallah UKSC above $\mathrm{n} 1$ at [12].

${ }^{341}$ The question posed by Gary Born in "Dallah and the New York Convention" (7 April 2011) Kluwer Arbitration Blog <www.kluwerarbitrationblog.com>.

${ }^{342}$ Dallah UKSC above n n1at [28] per Lord Mance.
} 
application of the law to those facts. Where an aggrieved party seeks redress, the subsequent proceedings could take the form of judicial review or some form of appeal. The phrase 'some form' is deliberately vague. As Park notes, language becomes important as language shapes choices, and without clarity of meaning or regard to context and function, similar words can have significantly different effects. ${ }^{343}$

Policy reasons for limiting the avenue for redress are straightforward. Generally, there is recognition that the first body, provided it follows procedure correctly, is better suited, or at least as well suited to determine factual matters. In addition, there is the principle of finality of litigation, and the greater interest in clarification of law rather that the facts of a particular case (and the corollary of allocating resources to only those important matters), as well as the general recognition in many cases, of the expertise of a particular body. ${ }^{344}$

Precise definitions are 'beyond reach' but the ways that a decision can be revisited may distinguish between law, fact, discretion, facts, and inferences. ${ }^{345}$ There is no bright line distinguishing these categories. The manner in which a question is constructed may define whether the same issue is a question of law or a question of fact. Further, determination of a question of fact requires a choice as to whether there is a single question as to whether the facts as found fall within a particular rule of law or if it is sufficient that the facts are reasonably capable of falling within such a rule. ${ }^{346}$ In this respect, the court has to be clear not just on how to fulfil its task, but what its task is, and that of the court or tribunal before it. Did the tribunal have to be right, or just not wrong? Is the court to decide the matter independently or assess how the tribunal decided it? Is a standard of correctness or reasonableness to be applied? Is the answer always the same or does it change with the context?

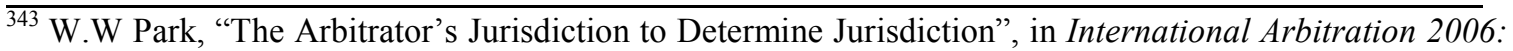
Back to Basics? (ICCA congress Series No. 13, Kluwer, The Hague, 2007) ${ }^{343}$ or (2007) ICCA Congress Series No. 13, 55 at 3.

${ }^{344}$ K. Keith "Appeals from Administrative Tribunals' The existing Judicial Experience" (1968 - 1970) 5 Victoria University Law Review 123 at 126.

${ }^{345}$ K. Keith “Appeals from Administrative Tribunals' The existing Judicial Experience” (1968 - 1970) 5 Victoria University Law Review 123 at 124.

${ }^{346}$ K. Keith “Appeals from Administrative Tribunals' The existing Judicial Experience” (1968 - 1970) 5 Victoria University Law Review 123 at 131.
} 


\section{The Nature of Review}

Dallah argued for a limited review. 'Review' in English law (and many common law jurisdictions) is traditionally linked with judicial review of administrative action. Judicial review is a common law remedy, simplistically characterised as review of the process or procedure by which a decision is made, rather than reconsideration of the merits of the decision.

The nature of review in the context of arbitral proceedings was considered in Mexico $v$ Cargill, Incorporated. ${ }^{347}$ Although this case involved an Investor State dispute under Chapter 11 NAFTA, ${ }^{348}$ the appeal was based on article 34(2) Model Law on the basis the tribunal had made an award that went beyond the submission to arbitration (equivalent to article V (1) (c) of the New York Convention). The case is therefore useful for its discussion on the standard of review to be applied and the relevance of a jurisdictional question.

In the first appeal, the judge noted the "powerful presumption" that tribunals act within their jurisdiction, and noted the requirements of international comity, holding that the standard was one of reasonableness (as contended for by Cargill), not the standards of correctness, (argued by Mexico). ${ }^{349}$ Both Canada and the United States of America, sought, and were granted leave to intervene in the subsequent appeal, as did ADR Chambers. In the latter case the primary purpose was to assist on the specific issue on the standard of review of a NAFTA decision, demonstrating the importance of the issue to the arbitration community. ${ }^{350}$

While the United States took no position regarding the standard of review, Canada supported Mexico's position that in questions of jurisdiction, the correct standard was

\footnotetext{
${ }^{347}$ Mexico v Cargill, Incorporated [2011] ONCA 622.

${ }^{348}$ North American Free Trade Agreement Between the Government of Canada, the Government of Mexico and the Government of the United States, 17 December 1992, Cam. T.S 1994 No. 2 (NAFTA).

${ }^{349}$ Mexico v Cargill, Incorporated [2011] ONCA 622 at [19].

350 Mexico v Cargill, Incorporated [2011] ONCA 622 at [27], [28]. ADR Chambers describes itself as "the leading Canadian organization that specializes in International Arbitration and Mediation. Through the use of the UNCITRAL Arbitration Rules as supplemented by its own state of the art rules, ADRCI provides practitioners and their client's uniformity and credibility in the field of the international arbitration and mediation. The mandate of ADRCI is to provide a single cost effective Canadian source for all types of international dispute resolution, including formal international arbitration, mediation, med-arb or other hybrid systems of dispute resolution." $<$ http://adrchambersinternational.com>.
} 
correctness while (unsurprisingly), Cargill agreed with the reasonableness standard taken by the Judge. ${ }^{351}$

However ADR chambers submitted that the proper description of the standard to be applied was the "highest degree of deference", arguing that domestic administrative law tests were irrelevant in reviews of international arbitration panels, and the grounds for review under the Model law were limited and exhaustive. Critically, it was said the court must not review the merits of an award under the guise of a jurisdictional enquiry. ${ }^{352}$

The Court of Appeal agreed that defining the standard of review clearly was important and that domestic concepts (whether from administrative law or domestic arbitrations) may not assist in the context of the Model Law. Noting that none of the grounds under Article 34(2) of the Model Law permit review on the merits, the Court referred to various Canadian authorities. These reflected the consistent view that a court should generally accord a high degree of deference to arbitral tribunals. However in certain matters, such as jurisdiction, some cases considered the standard of review was correctness, while others cases distinguished between those circumstances where the tribunal had to be correct (i.e. where question of law were involved) or merely reasonable (mixed question of fact and law). ${ }^{353}$

When determining if an award complies with the submission to arbitrate, the wording of Article 34(2) (a) (iii) provided no standard, but nor did the Court consider anything in its wording should detract from the usual principle that a tribunal could not act beyond its jurisdiction. After referring to the Canadian decision of Dunsmuir ${ }^{354}$ (made in the administrative law context), Feldman J.A, held: ${ }^{355}$

The tribunal therefore has to be correct in the sense that the decision it made had to be within the scope of the submission and the NAFTA provisions. Its authority to make any decision is circumscribed by the submission and the provisions of the NAFTA as interpreted in accordance with international law. It has no authority to expand its jurisdiction by incorrectly interpreting the submission of the NAFTA even if its interpretation could be viewed as a reasonable one.

\footnotetext{
${ }^{351}$ Mexico v Cargill, Incorporated [2011] ONCA 622 at [27].

${ }^{352}$ Mexico v Cargill, Incorporated [2011] ONCA 622 at [28].

${ }^{353}$ Mexico v Cargill, Incorporated [2011] ONCA 622 at [33] referring, in addition to the authorities cited by the lower court, to Canada (Attorney-General) v S.D. Myers, Inc [2004], 3 F.C.R. 368.

${ }^{354}$ Dunsmuir v New Brunswick [2008] 1 .S.C.R 190.

${ }^{355}$ Mexico v Cargill, Incorporated [2011] ONCA 622 at [41].
} 
In contrast, the reasonableness standard was considered to inevitably lead to a review on the merits. The conclusion that the tribunal had to be correct in its determination that it had the ability to make the decision it did, was viewed as consistent with the reasoning in Dallah. ${ }^{356}$ Feldman J.A was careful to point out that the questions for each Court were not the same, and in any event, that this standard of correctness did not give broad scope for intervention in the decisions of international tribunals. ${ }^{357}$

Cargill demonstrates how the approach was determined by both the substance of the dispute (a question of jurisdiction), and the court's view of its function on that issue, which was to ensure the tribunal has reached the correct decision, not merely a reasonable one. However it also highlights the different ways that courts can conceive of what is a jurisdictional question, what is a question of law, what is a question of fact - and the consequences that might follow. The issue in Cargill was whether the tribunal could award "Up Stream Losses" for damage suffered to Cargill's business in the United States as a result of the breach, rather than just the business in Mexico as an investor. This was regarded as question of jurisdiction. Ultimately it was decided on the basis that as the tribunal had a made a finding of fact and applied that fact to the definition, it was not outside its jurisdiction. The question of damages was a quintessential one of fact for the tribunal.

A somewhat different view of a similar issue was taken in Lesotho Highlands. ${ }^{358}$ In that case, the question of whether the tribunal had exceeded its power by awarding damages in certain currencies was squarely considered to be one where the tribunal had (at most) made an erroneous exercise of a power it did have (by implication it did not have to be correct) rather than purporting to exercise a power it did not have. The latter view was considered reminiscent of excess of jurisdiction cases in the public law sense. ${ }^{359}$

The approach in Leostho and the Cargill clearly signal the connections to the public law nature of review and jurisdiction in common law jurisdictions. With it comes the inherent assumption that review means a restriction on factual determinations. In contrast, under the French Civil Code, the power to review an award includes the power to conduct

\footnotetext{
${ }_{356}$ Mexico v Cargill, Incorporated [2011] ONCA 622 at [43].

${ }^{357}$ Mexico v Cargill, Incorporated [2011] ONCA 622 at [39], [42] - [44].

358 Lesotho Highlands Development Authority v. Impregilo SpA above n 166 at [22] - [24] per Lord Steyn.

${ }^{359}$ For example, Anisminic Ltd v Foreign Compensation Commission [1969] 2 A.C 147 (H.L).
} 
a review of "all legal and factual elements that relevant to determine the scope of the arbitrating agreement and draw the corresponding conclusion regarding the arbitrator's compliance with their mission". ${ }^{360}$ As noted above, that does not generally include hearing factual witness.

\section{The Nature of Appeal}

Against that background, judicial review can be contrasted with appeal rights, which perhaps share more with the idea that the court's role is to ensure a decision is 'correct'. However, even if it is accepted that a 'correct' decision is required, there remain options to a court in how to approach that task. Though appeals are statutory rights their nature can vary significantly, from de novo appeal, a general appeal, appeal on a question of law, or appeal from discretion.

For example, an appeal on a point of law is limited to a question of law, where only errors of law may be advanced. The facts as decided at first instance will be undisturbed. Generally only the same material that was before the decision maker at first instance will be considered. In some rare cases there may be provision for further evidence to be adduced. However where new evidence may be permitted, only evidence that goes to the error of law, not of fact, will usually be allowed.

This is more limited than a general appeal, where the court can reverse findings of fact. In a general appeal, additional evidence may be adduced in certain limited cases, but the burden of proof will remain on the appellant. In contrast, a de novo appeal usually means the burden of proof remains on the party who bore it at first instance. The appellate body will decide the matter afresh, as if they were the original decision maker. The position is different again, if the original decision was in respect to a matter of discretion. Although the court will not substitute its view, the decision may be overturned if "plainly wrong.",361

\footnotetext{
${ }^{360}$ Fondation Albert Abela Family Fondation (AAFF) et. al. v. Fondation Joseph Abela Family Fondation $(J A F F)$, Revue de l'Arbitrage (2010), p. 813 et seq. (Cour de Cassation, First Civil Chamber,). A further distinction (not discussed in Dallah) was that it is only at the award stage that a French court will be able to consider any objection.

${ }^{361}$ K. Keith "Appeals from Administrative Tribunals' the existing Judicial Experience" $(1968$ - 1970) 5 Victoria University Law Review 123, at 134.
} 
Context and purpose become relevant. A useful starting point for comparison to the requirement for mandatory de novo re hearing decided in Dallah can be found within the English Arbitration Act 1996, in cases where that Act is the law governing the arbitration.

The English legislation confirms how the substance of a matter dictates the approach, differing when the issue is one of substantive jurisdiction, serious irregularities or an appeal on a question of law.

\section{Different approaches under the English Arbitration Act 1996}

\section{Section 67 Arbitration Act 1996 (UK)}

Section 67 of the English Arbitration Act 1996 provides for an award to be "challenged" for lack of substantive jurisdiction. For the purpose of s 67 "substantive jurisdiction" means the matters specified at s. 30(1)(a)-(c) of the Act, namely (a) whether there is a valid arbitration agreement (b) whether the tribunal is properly constituted, and (c) what matters have been submitted to arbitration in accordance with the arbitration agreement. ${ }^{362}$

The manner in which the courts interpret this provision emphasises the elevated importance that is attached to establishing the existence of an arbitral agreement (which forms the basis for arbitration) and the English view that only a court can decide these fundamental matters. Although s 30 provides generally that any ruling by a tribunal on its own substantive jurisdiction may be challenged by any arbitral process of appeal or "review in accordance with the provisions of this Part,",363 s 67 uses the term "challenge." Consequently, the English courts have had to consider what "challenge" meant in terms of the courts task and how it should fulfil it. ${ }^{364}$ One of the first (and most often cited case) to consider the issue was Azov Shipping Co. v Baltic Shipping Co, discussed earlier.

In that case, Rix J posited the decision firmly on the facts of the case before him. He noted the interest in parties first having an arbitrator determine jurisdiction, and that "in

\footnotetext{
362 s 82(s) Arbitration Act 1996.

${ }^{363}$ s30 Arbitration Act confirms the ability of a tribunal to rule on its own jurisdiction- the principle of competence-competence, though under English law it is a procedural rather than a substantive power.

${ }^{364}$ S. 30 Arbitration Act 1996 (UK) This confirms the ability of a tribunal to decide its own jurisdiction under the principle of competence-competence. Though under English law it is a procedural rather than a substantive power.
} 
many cases, and perhaps in the ordinary and normal case of such a challenge" the arbitrator's decision may be accepted, distinguishing cases where the issue was whether a party was bound to the relevant contract or not. ${ }^{365}$ However, he went on to say: ${ }^{366}$

Where, however, there are substantial issues of fact as to whether a party has made the relevant agreement in the first place, then it seems to me that, even if there has been a full hearing before the arbitrators the Court, upon a challenge under s. 67, should not be placed in a worse position than the arbitrator for the purpose of determining that challenge.

That was particularly so where the arbitrator came to the final decision with uncertainty. Rix J referred the DAC report comment which said "A challenge to jurisdiction may well involve questions of fact as well as questions on law." ${ }^{367}$ Ultimately, Rix J concluded on the facts before him that "a question of justice, where it conflicts with a modest prejudice to expedition or increase in cost, must be given greater weight.",368

Later decisions crystallised that into a hard rule ${ }^{369}$ though in subsequent proceedings, Longmore $\mathrm{J}$ gave security for costs to Baltic for the re-hearing, noting it as relevant that Azov had lost before the arbitrator, and could effectively be having "a second bite at the same cherry". ${ }^{370}$ Although any subsequent re-hearing would be approached afresh, that did not mean the arbitrator's decision had no relevance in the context of the application of security for costs, though on the facts was afforded less weight than the question of whether Azov had sufficient assets. ${ }^{371}$

365 Azov Shipping Co. v Baltic Shipping Co. [1999] 1 Lloyds Rep 68 at 70.

${ }^{366}$ Azov Shipping Co. v Baltic Shipping Co. [1999] 1 Lloyds Rep 68 at 70.

${ }^{367}$ Departmental Advisory Committee on Arbitration Law at 43, 1 Azov Shipping Co. v Baltic Shipping Co. [1999] 1 Lloyds Rep 68 at 70.

${ }^{368}$ Azov Shipping Co. v Baltic Shipping Co. [1999] 1 Lloyds Rep 68 at 71.

369 Astra SA Insurance v Sphere Drake Insurance [2002] 2 Lloyd's Rep 550 ( per David Steel J), Aoot Kalmneft v Glencore International AG [2002] 1 Lloyd's Rep 128 (per Coleman J), Electrosteel Castings v Scan-Trans Shipping [2002] EWHC 1993 (Comm) (per Gross J), Zaporozhye Productin Society v Ashley Limited [2002] EWHC 1410 (Comm) per Tomlinson J), People's Insurance Co of China v Vysanthi Shipping Co [2003] EWHC 1655 (Comm) per (Thomas J), Peterson Farms Inc v C \& M Farming Ltd [2004] EWHC 121 (Comm) per Langley J), The Republic of Serbia v Imageat International NV [2009] EWHC 2853 (Comm).

${ }^{370}$ Azov Shipping Co. v Baltic [1999] 2 Lloyd's Rep 39.

${ }^{371}$ Azov $v$ Baltic above n 372 at 41. 
However the provisional nature of an arbitrator's decision has since been expressly restated by the Commercial Court in Republic of Serbia v Imagesant International $\mathrm{NV}^{372}$ "That sweeping pronouncement" Born says is "difficult to reconcile with the proposition that arbitral awards are final and binding between the parties, subject to limited judicial oversight with substantial deference being afforded to the arbitrators decision." 373

The hardening of the rule about the nature of the courts role under s 67 has not been without some dissent from the ranks. Although an earlier decision in Ranko Group v Antarctic Maritime $S A^{374}$ has gone largely unnoticed, Morison J in Tajik Aluminium Plant $v$ Hydro Aluminium $A S^{375}$ considered the nature of the review conducted by the court should be determined by nature of the challenge and the circumstances in which it is made. ${ }^{376}$ Although bound by authorities to hold that a re-hearing (at least on the jurisdictional question) was required, the facts of that case highlighted the consequences that would arise: a full trial extending over 12 days with extensive factual and expert evidence "trying to shore up" the weakness of the case identified by the arbitrator. In other words, a second bite on a matter that had been the subject of a full trial. ${ }^{377}$

Referring back to the DAC Report cited in the earlier decision, and the statement that challenges to jurisdiction may well involve questions of facts as well as law, ${ }^{378}$ Morison $\mathrm{J}$ notes that still left open the question as to how the facts should be challenged, which again, he considered would depend on the circumstances: ${ }^{379}$

\footnotetext{
372 Republic of Serbia v Imagesant International NV [2009] EWHC 2853 at [8]. "The arbitrator's determination can only be provisional. It "cannot be conclusive between the parties because of the nature of the intrinsic issue, for his jurisdiction can only be founded on the very mutual assent which is in issue": citing Azov Shipping Co. v Baltic [1999] 2 Lloyd's Rep 159, at 161, per Colman J.

373 Gary Born, "Who is most competent? Some comments on the Allocation of Jurisdictional competence under the English Arbitration Act 1996" (2010) Kluwer Arbitration Blog

$<$ www.kluwerarbitrationblog.com>.

${ }^{374}$ Ranko Group v Antarctic Maritime SA [1998] LMLN 492.

${ }^{375}$ Tajik Aluminium Plant v Hydro Aluminium AS [2006] EWHC 1135 (Comm).

${ }^{376}$ Tajik Aluminium Plant v Hydro Aluminium AS [2006] EWHC 1135 (Comm) at 38.

${ }^{377}$ Tajik Aluminium Plant v Hydro Aluminium AS [2006] EWHC 1135 (Comm) at 38.

378 "A challenge to jurisdiction may well involve questions of fact as well as questions of law. Since the arbitral tribunal cannot rule finally on its own jurisdiction, it follows that both its findings of facts and its holdings of law may be challenged. The regime for challenging such awards is set out in Clause 67." Departmental Advisory Committee on Arbitration, at para 143, referred to in Tajik Aluminium Plant $v$ Hydro Aluminium AS [2006] EWHC 1135 (Comm) at 41.

${ }^{379}$ Tajik Aluminium Plant v Hydro Aluminium AS [2006] EWHC 1135 (Comm) at 42.
} 
In my judgment,.... the challenge which this court should embark on is essentially no different from the way the Court of Appeal itself deals with appeals of facts and law. In my view it is not a re-trial; the court's role is to examine the findings of fact made by the arbitrators to ascertain whether any finding was unsupported by evidence or was against the weight of the evidence in the light of the Tribunal's assessment of the credibility of the witnesses.

The consequences of a rehearing were pointed out by Morison J, in apparent response to earlier judgments that emphasised the court would retain case management powers, observing there could be no half way house. ${ }^{380}$ If the power to challenge includes power to challenge the facts, Morison J observed there is no discretion for the court to refuse to admit otherwise admissible evidence. ${ }^{381}$

This position illustrates the small but significant shift from the initial decision in Azov Shipping. First Azov was a decision whether to give directions permitting a rehearing. So there was at the outset a hurdle to cross before the decision to grant a re-hearing was made. Second, the decision was made very clearly on an assessment of the facts of the particular case. That included the subject matter in dispute, whether a party had made the agreement to arbitrate in the first place, the hesitant nature of the arbitrators conclusion, the fact there were substantial issues of fact in dispute, and an assessment that the interest of justice will be given greater weight compared to a "modest prejudice to expedition or increase in costs. $" 382$

The original decision is a vastly different position to mandatory rehearing wherever the validity of an award is challenged. This is not insignificant given the reliance on s 67 to support the conclusion for a rehearing in Dallah.

\section{Section 68 Arbitration Act 1996 (UK)}

Section 68 of the Arbitration Act enables a challenge to be made where there is a "serious irregularity." Unlike s 67, s 68 seems to assume the tribunal had substantive jurisdiction. It deals with procedural matters rather than concerning itself with the nature of the reasoning in the awards. ${ }^{383}$ For the purpose of s 68 , "serious irregularity" means an

$\overline{380}$ Tajik Aluminium Plant $v$ Hydro Aluminium AS [2006] EWHC 1135 (Comm) at [44] referring to Primetrade A.Gv Ythan Ltd [2005] EWHC 2399.

${ }^{381}$ Tajik Aluminium Plant v Hydro Aluminium AS [2006] EWHC 1135 (Comm) at [44.]

${ }^{382}$ Azov Shipping Co. v Baltic Shipping Co. [1999] 1 Lloyds Rep 68 at 71.

${ }^{383}$ Lesotho Highlands Development Authority v. Impregilo SpA [2005] 3 UKHL 43 at [28]. 
irregularity of one or more of the following kinds which the court considers has caused, or will cause, substantial injustice to the applicant-

(a) Failure by the tribunal to comply with section 33 (general duty of tribunal);

(b) The tribunal exceeding its powers (otherwise than by exceeding its substantive jurisdiction: see section 67);

(c) Failure by the tribunal to conduct the proceedings in accordance with the procedure agreed by the parties;

(d) Failure by the tribunal to deal with all the issues that were put to it;

(e) Any arbitral or other institution or person vested by the parties with powers in relation to the proceedings or the award exceeding its powers;

(f) Uncertainty or ambiguity as to the effect of the award;

(g) The award being obtained by fraud or the award or the way in which it was procured being contrary to public policy;

(h) To comply with the requirements as to the form of the award; or

(i) any irregularity in the conduct of the proceedings or in the award which is admitted by the tribunal or by any arbitral or other institution or person vested by the parties with powers in relation to the proceedings or the award.

The high threshold for intervention under s. 68 represented a new concept in English law, its language said to be drawn from the language and jurisprudence of Article V (1)(c) of the New York Convention. ${ }^{384}$ In the context of the New York Convention this had been accepted to mean its provisions required a narrow construction, and the policy underpinning the DAC report pointed to a similarly restrictive interpretation.

That s 68 is focused on procedural matters was reiterated in the decision of $B v A^{385}$ which involved a question of whether the arbitrators had correctly applied Spanish law to the substance of the dispute. The Court confirmed that an error of law did not amount to excess of power under s 68 (or relate to substantive jurisdiction under s 67) with Tomlinson $\mathrm{J}$ observing the position would be the same whether the chosen law was English law or foreign law. ${ }^{386}$

The distinction between error of law under s 68 and an error that went to jurisdiction was drawn in Lesotho Highlands (discussed earlier), making clear that a challenge under s 68

${ }_{384}$ Lesotho Highlands Development Authority v. Impregilo SpA [2005] UKHL 43 at [30].

${ }^{385} B v A$ (Rev 1) [2010] EWHC 1626 (Comm).

${ }^{386} B v A(\operatorname{Rev} 1)$ [2010] EWHC 1626 (Comm) at [26]. 
will not lie simply because the tribunal failed to arrive at the correct decision. There is a high threshold. ${ }^{387}$

\section{Section 69 Arbitration Act 1996 (UK)}

Unlike many other jurisdictions, English law retains a right of appeal on error of law. This represents a departure from the general position in arbitration proceedings that the merits of a decision are free from review by national courts. Section 69 of the Arbitration Act 1969 (UK) provides that unless otherwise agreed by the parties, a party to arbitral proceedings may (upon notice to the other parties and to the tribunal) appeal to the court on a question of law arising out of an award made in the proceedings. In the absence of agreement, the right to appeal is subject to the leave of the court which will only be given, if the court is satisfied: ${ }^{388}$

(a) that the determination of the question will substantially affect the rights of one or more of the parties,

(b) that the question is one which the tribunal was asked to determine,

(c) that, on the basis of the findings of fact in the award-

(i) the decision of the tribunal on the question is obviously wrong, or

(ii) the question is one of general public importance and the decision of the tribunal is at least open to serious doubt, and

(d) that, despite the agreement of the parties to resolve the matter by arbitration, it is just and proper in all the circumstances for the court to determine the question.

The background to these provisions lies in the case stated provision under earlier English arbitration law. Under the Arbitration Act 1950 there were two mechanisms by which the English Courts could intervene in arbitral proceedings. The first arose out of the inherent jurisdiction of the Court to set aside awards for errors of fact or law on the face of the award. In practice, this seemed not to provide any great recourse as it encouraged a practice of arbitrators either not providing, or providing separately, the reasons for the award. ${ }^{389}$ The second was the retention of the case stated procedure under s 21 of the Arbitration Act 1950.

\footnotetext{
387 Lesotho Highlands Development Authority v. Impregilo SpA [2005] UKHL 43 at [28].

${ }^{388}$ Section 69 Arbitration Act 1996 (UK).

389 A. J Kolodiej “Arbitration Act 1979: Genesis and Operation” (1987) 8(5) Company Lawyer 206 - 212 at 206.
} 
The origins of section 21 lay in the Common Law Procedure Act 1854 and allowed an arbitrator or, on application of a party direct to the court, the court itself to state a question of law for the court to determine. The criteria when a case should be stated was set out in The Lysland ${ }^{390}$ a decision described as "the death knell of arbitrator autonomy." ${ }^{391}$ Lord Denning said it must a point of law "real and substantial and such as to be open to serious argument and appropriate for a decision any a court of law...clear cut and capable of being accurately stated as a point of law... of such importance that the resolution of it is necessary for the proper determination of the case. ${ }^{„ 392}$ In that case, the case was stated notwithstanding the arbitrator's objection, and consequently the prevailing view was that a failure by the arbitrator to state a case on request would form a basis for an award to be set aside on the grounds of arbitrator misconduct. ${ }^{393}$

The initial benefits of the case stated procedure, which were recognised as promoting the responsibility of arbitrator and aiding the development of commercial law, were said to have been eroded from the early 1970's, as the case stated procedure became a tool of abuse in arbitration matters. ${ }^{394}$ Under the new 1979 Act the case stated procedure was abolished and replaced with far more limited rights of appeal. The Act provided for parties to, by agreement, contract out of the right to appeal or to apply for determination of preliminary points of law.

Preliminary determinations were retained under the reforms, but under tighter control: the consent of the arbitrator or all parties was required, and even then, the court should not entertain such an application "unless satisfied that it would produce substantial cost savings to the parties and the question of law is one in respect of which leave to appeal under section 1 would be likely to be given". ${ }^{395}$ However, to obtain the support of the judiciary (Lord Diplock in particular) certain categories of cases were excluded from the

\footnotetext{
${ }^{390}$ Halfdan Grieg \& Co A/S v Sterling Coal and Navigation Co (The Lysland) [1973] 2 W.L.R 237

${ }^{391}$ Park, "Judicial Supervision of Transnational Commercial Arbitration: The English Arbitration Act of 1979 above $\mathrm{n} 225$ at 93 .

392 Park ,above n 225at 95.

${ }^{393}$ Park, above n 225 at 94

${ }^{394}$ A. J Kolodiej “Arbitration Act 1979: Genesis and Operation” (1987) 8(5) Company Lawyer 206 - 212 at 207. However a survey of cases subject to the case stated process between 1960 and 1970 undertaken by William Park in 1980 cast doubt on claims the process was simply a delaying tactic for underserving parties and suggest the procedure continued to play a positive role in the law. Substantive issue were raised, not merely trivial issues, but this was inevitably at the expense of certainty and finality to the litigation as the High Court overturned the arbitrator decision in 21 of the 54 cases reviewed. Park, "Judicial Supervision of Transnational Commercial Arbitration: The English Arbitration Act of 1979 above n 225 at 93.

${ }^{395}$ Pioneer Shipping Ltd v B.T.P Tioxide Ltd (“The Nema”) [1981] 3 W.L.R 292 (H.L)
} 
provisions enabling parties to contract out of judicial review: These included admiralty, insurance and commodity cases, which were seen as "the water in the fountain of the development of English commercial law." "396 The history and development emphasise the focus on the development of the law rather than the individual justice of the case. The threshold for an appeal under s 69 Arbitration Act 1996 broadly reflects the threshold that had been developed by the courts themselves in what was viewed as the time as indicating a preference for finality over certainty. ${ }^{397}$

Appeals under section 69 are limited to a question of law, and made on the facts as determined by the arbitrator. ${ }^{398}$ The position stated by Lord Steyn under the 1979 Act has been held to be equally relevant under the 1996 Act: ${ }^{399}$

... The arbitrators are the masters of the facts. On an appeal the Court must decide any question of law arising from an award on the basis of a full and unqualified acceptance of the findings of fact of the arbitrators. It is irrelevant whether the Court considers those findings of fact to be right or wrong.

In the same case, Lord Steyn cautioned the courts to carefully identify and discouraged ensure attempts to dress up questions of fact as questions of law, ${ }^{400}$ a vigilance echoed by Justice Simon for cases under the 1996 Act. Justice Simon re-stated the restrictions on adducing any more than the arbitral awaits and agreement as evidence in any appeal noting the principle has been the subject of two recent statements of by Judges of the Commercial Court in Great Western Trains Co. Ltd v Network Rail Infrastructure Ltd ${ }^{401}$ and Sylvia Shipping Co Ltd v. Progress Bulk Carriers Ltd (The 'Sylvia'). ${ }^{402}$

\footnotetext{
$\overline{396}$ This itself was not without some conflicting views:, the retort attributed to Lord Devlin being "So there must be an annual tribute of disputants to feed the Minotaur's. The next step would, I suppose, be a prohibition placed on settlement of cases containing interesting points of law. "Lord Hacking "The Story of the Arbitration Act 1979" (2010) 76 Arbitration 125 at 128.

${ }^{397}$ In The Nema above n 397.

${ }^{398}$ Dolphin Tanker SRL v Westport Petroleum Inc [2010] EWHC 2617 (Comm).

399 Geogas SA v. Trammo Gas Ltd, The 'Baleares' [1993] 1 Lloyd's Rep 215, at 227 cited with approval by Mr. Justice Simon in Dolphin Tanker above n 400 at [29] who went on to say "The same vigilance will be applied to cases under the 1996 Act"

${ }^{400}$ Geogas SA v. Trammo Gas Ltd, The 'Baleares' [1993] 1 Lloyd's Rep 215, at 227.

${ }^{401}$ Great Western Trains Co. Ltd v Network Rail Infrastructure Ltd ${ }^{401}$ [2010] EWHC 117 (Comm) at [89].

${ }^{402}$ Sylvia Shipping Co Ltd v. Progress Bulk Carriers Ltd (The 'Sylvia') [2010] EWHC 542 (Comm) "As a general rule, the only documents which should be put before the court on an arbitration appeal are the award itself and the relevant contract. Unless clearly incorporated by reference, other arbitration documents are usually irrelevant and inadmissible. Unless there is a disputed issue as to whether the question of law
} 
The context and function of s. 69 gives a clear direction on the nature of the judicial decisions. It is squarely framed as an appeal, it is expressly stated to be limited to questions point of law, and it developed because of the general importance that was attached in the English legal system to the development of English commercial law, rather than the particular facts of any one case. The courts themselves have continued to have regard to the purpose for which it was designed.

\section{Thresholds or Presumptions}

As stated earlier, in the context of the New York Convention, "fine tuning the points of intersect between the roles of the court and the tribunal has to take place outside its literal text."403 Notwithstanding Lord Justice Moore-Bick's expressed scepticism at the ability to develop a test capable of flexible application, this is bread and butter work for common law jurisdictions. There are cases that provide a good example of the nuanced approach courts can develop to deal with competing principles in international arbitration.

\section{Presumption towards arbitration}

The decision in Fiona Trust ${ }^{404}$ was heralded as a "pro arbitration" decision. The case dealt with the question of whether the validity of an arbitration clause could be affected by the claim of bribery as to inducement (and therefore was dealt with under the provisions of separability). Though recognising arbitration as consensual, the House of Lords referred to the fact the 1996 Act reflected commercial expectations, so the meaning and interpretation of the words used would be influenced by the commercial background: 405

Businessmen in particular as are assumed to enter into agreements to achieve some rational purpose and an understanding of this purpose will influence the ways on which one interprets their language.

was one which the tribunal was asked to determine, the same applies to applications for permission to appeal" at [88] Per Hamblen J.

${ }^{403}$ Amokura Kawharu "Arbitral Jurisdiction” (2008) 23 New Zealand Universities Law Review 238 at 264.

${ }^{404}$ Fiona Trust \& Holding Corp v Privalov [2007] UKHL, also cited as Premium Nafta Prod Ltd v Fili Shipping Co [2007] UKHL 4019 (U.K), [2007] BUS LR 1719.

${ }^{405}$ Fiona Trust \& Holding Corp v Privalov [2007] UKHL 40 at [5] per Lord Hoffman. 
In assessing the commercial purpose of arbitration clauses, particularly in the international context Lord Hoffman identified a desire for quick and efficient adjudication, avoiding risks of delay and partiality, in proceedings before national courts. ${ }^{406}$ The commercial realities of the business community were reflected in the court's indication that court's will construe the scope of arbitration clauses broadly, and where possible in favour of arbitration. Clear and express words are required if a party wants to suggest that different tribunal or court should decide different matters, "Otherwise they will be taken to have agreed on a single tribunal for the resolution of all such disputes." 407

Fiona Trust, ended then, with the presumption being that where there was an arbitration clause commercial parties would want all matters determined by arbitration. The argument against such a presumption (and thereby for de novo review) is the right of access to the courts. It is not clear whether this was intended from Lord Collins reference to 'fundamental rights' and the right to object to jurisdiction. The Court did not elaborate on the nature of these fundamental rights, so their nature and content was not defined.

This right of access to the court is reflected variously as a basic principle of democracy, a constitutional right or of fundamental human rights. Certainly, the public policy of ensuring access to the courts long stood at the heart of English court's limitations on arbitration. This was evident in 1922 when the English Court of Appeal rejected any suggestion an arbitrator could wrongly apply the law and avoid judicial review by contract, with Lord Justice Scrutton declaring "There must be no Alsatia in England where the King's writ does not run." 408

However, basing decisions on the right of access to the courts includes an inherent assumption that a party wants access to a court - and to have a court decide the dispute. For the reasons discussed by the House of Lords in Fiona Trust, that assumption is not

\footnotetext{
${ }^{406}$ Fiona Trust \& Holding Corp v Privalov [2007] UKHL 40 at [6] per Lord Hoffman. Lord Hoffman went on at paragraph [7] to note that section 7 of the Arbitration Act "on shows a recognition by Parliament that, for the reasons I have given in discussing the approach to construction, businessmen frequently do want the question of whether their contract was valid, or came into existence, or has become ineffective, submitted to arbitration and that the law should not place conceptual obstacles in their way."

${ }^{407}$ Fiona Trust \& Holding Corp v Privalov [2007] UKHL 40 at [26] per Lord Hope.

${ }^{408}$ Czarnikow v Roth Schmidt \& Co [1922] 2 KB 478 at 488. Alsatia was an area in London reportedly known as a sanctuary for debtors. See W. W Park "The Lex Loci Arbitri and International Commercial Arbitration" (1983) 32 International and Comparative Law Quarterly 21 at 34, citing Plucknett, Concise History of the Common Law (5 ${ }^{\text {th }}$ edn, 1956) at 431.
} 
born out in international commercial disputes. It does not seem unreasonable to consider that where parties have indicated a preference for arbitration in that context generally, it would want future disputes of the same nature decided in the same way. If correct, what is the nature of right that is being protected by prioritising the right of access to the court? Arguably, it is less about access to courts, but rather 'a right' not to have the substantive rights decide by arbitration, or - the right not have that particular dispute decided by that particular arbitral tribunal?

If the content of the right is different, the context of proceedings takes on a different shape. For example this might suggest a stronger presumption in favour of arbitration where there is doubt, or a different evidential basis, or standard of proof to be applied. That would be consistent with the general recognition of arbitration as a preferred mechanism for dispute resolution, and the fundamental objective of avoiding litigation national courts in cross border commercial disputes.

This shifts of course, the nature of consent from being consent in the particulate case, to an agreement to arbitration as a forum more generally. In Dallah, the initial Memorandum of Understanding between Dallah and the MORA did include an arbitration clause. The existence of this arbitration clause provided some comfort to two of the arbitrators. ${ }^{409}$ The court avoided these issues altogether by simply framing the issue as an excess of arbitral jurisdiction.

\section{Deference to findings of Tribunal}

Like questions of jurisdiction, (even) English courts have confirmed that arbitrators can deal with allegations of bribery, fraud or corruption. ${ }^{410}$ Unlike the limitations on competence-competence, courts are generally comfortable that tribunals can adequately and finally deal with such allegation, provided the issue has been raised, argument considered and ruled upon. ${ }^{411}$ In this case the tension is between the public interest in the

\footnotetext{
${ }^{409}$ The FPA recording that Dr Shah and Lord Mustill were reassured "the more so given the background of the Memorandum of Understanding in which the participation of the State was not in doubt." See above n 135 .

${ }^{410}$ Fiona Trust $v$ Privalov [2007] [2007] UKHL 40 and Bilta (UK) Ltd v Muhammad Nazir [2010] All ER (D) 146.

${ }^{411}$ Westacre v Jugoimport [1999] All ER (D) 486 Westacre Investments Inc v Jugoimport-SPDR Holding Co Ltd and ors [2000] 1 QB 288 (“Westacre").
} 
finality of litigation and the fact enforcement of illegal contracts would be against public policy. ${ }^{412}$

In Soleimany v. Soleimany ${ }^{413}$ (though not necessary to decide the issue in that case), the English Court of Appeal suggested a two-stage test: first, to consider whether to give full faith and credit to the award; and second, only if the court was satisfied that the award was unsafe, should the court embark on a more elaborate inquiry on the issue of illegality: $:^{414}$

In our view, an enforcement judge, if there is prima facie evidence from one side that the award is based on an illegal contract, should enquire further to some extent. Is there evidence on the other side to the contrary? Has the arbitrator expressly found that the underlying contract was not illegal? Or is it a fair inference that he did not reach that conclusion? Is there anything to suggest that the arbitrator was incompetent to conduct such an enquiry? May there have been collusion or bad faith, so as to procure an award despite illegality. Arbitrations are after all, conducted in a wide variety of situations, not just before high powered tribunals. We do not for one moment suggest that the Judge should conduct a full scale trial of these matters in the first instance. That would create the mischief which the arbitration was designed to avoid.

This two stage approach was considered in the 2011 decision AJU $v A J T .^{415}$ The Singapore Court of Appeal endorsed the importance of the principle of finality, and allowed an appeal against the decision of the High Court setting aside an interim award under Article 34(2) (b) (ii) of the Model Law (on the ground the interim award was contrary to the public policy of Singapore).

In that case, following the initiation of arbitral proceedings by AJT (who had been assigned to the contract initially entered into between AJU and P, a related party to AJT), AJU made a formal complaint to the Thai Police ${ }^{416}$. The complaint was against the sole director of AJT and two related companies (including P), alleging fraud, forgery and use of a fraudulent document. Under Thai law only the fraud offence was compoundable.

\footnotetext{
$\overline{412}$ Soleimany v. Soleimany [1999] QB 785 at [51] per Waller LJ.

${ }^{413}$ Soleimany v. Soleimany [1999] QB 785.

${ }^{414}$ Soleimany v. Soleimany [1999] QB 785.

${ }^{415} A J U v$ AJT [2011] SGCA 41, [2011] 4 SLR 739.

${ }^{416}$ The facts are set out in AJU $v A J T$ [ [2011] 4 SLR 739 at 739-740.
} 
The parties negotiated a settlement, subsequently recorded in a Concluding Agreement ("the Agreement") dated 4 February 2008. The key provisions of the Agreement provided for "withdrawal and/or discontinuation and/or termination of the Thai criminal proceedings." Following this, AJU would pay AJT US $\$ 470,000$ and both parties would "take all such steps as are necessary or desirable to simultaneously and irrevocably terminate, withdraw and discontinue all actions, claims and counterclaims as applicable to the respective parties in the Proceedings and in any other form or other action, as well as to vacate any judgments, awards, or enforcement that may have been issued or are subsequently issue." Singapore was specified as the governing law.

The complaint was then withdrawn by AJU. AJU received a non-prosecution order issued by the Thai authorities, in respect of all complaints, on the basis of insufficient evidence.

Notwithstanding these steps, AJT alleged the terms of the Agreement had not been met and refused to terminate the arbitral proceedings. The primary complaint was that a statement of non-prosecution did not mean an investigation could not be re-opened, whereas the agreement required the police investigation to end. In response to AJU's subsequent application to the Tribunal for termination of the arbitral proceedings (on the basis of full and final settlement), AJT alleged the Concluding Agreement itself was invalid.

Ultimately the parties agreed to submit the question of whether the Agreement between them should be set aside or declared void on the basis of duress, undue influence and/or illegality to the Arbitral Tribunal. AJT confirmed it would not seek to challenge the agreement in any other forum. The Tribunal held the agreement was valid and enforceable, rejecting the allegations of illegality or that it was procured by undue influence or duress, or bribery of the Thai authorities to obtain the non-prosecution orders. AJT applies to have the award set aside on the basis it was contrary to the public policy of Singapore.

First, in the Singapore High Court ${ }^{417}$, after reviewing the authorities ${ }^{418}$, concluded that in exercising its 'supervisory' jurisdiction, the court may examine the facts of the case and decide the issue of illegality: ${ }^{419}$

\footnotetext{
$\overline{417} A J T$ v AJU [2010] SGHC 201, [2010] 4 SLR 649.

${ }^{418}$ Including Soleimany v. Soleimany above n 418, and Westacre Investments Inc v Jugoimport-SPDR Holding Co Ltd and ors [2000] 1 QB 288 ("Westacre") above n 417. See generally above n 424 at 655-660. ${ }^{419}$ AJT v AJU [2010] SGHC 201aove n 424 at [24].
} 
While there is a need to uphold the public interest in ensuring the finality of arbitral awards, the court must also safeguard the countervailing public interest in ensuring that its processes are not abused by litigants.

On the facts, the Court considered the facts the Tribunal's finding was not conclusive and allowed the appeal, setting aside the award. Consequently, bBefore the Court of Appeal the issues were whether the Judge was correct in going behind the interim award and reopening the Tribunal's finding that the Concluding Agreement was valid and enforceable, and in any event, whether the Judge was correct in finding that the Concluding Agreement was illegal.

The "interventionist" approach of Soleimany and the dissenting judgment of Waller LJ in Westacre (CA) were compared to the approach of Colman $\mathrm{J}$ at first instance in Westacre and the majority approach of the English Court of Appeal in Westacre. ${ }^{420}$ The latter decisions essentially gave a greater degree of deference to a tribunal's findings as long as the illegality argument was made, entertained and ruled upon.

The latter approach was preferred and the appeal was allowed ${ }^{421}$. While the Court of Appeal considered the Judge was incorrect to find the Concluding Agreement was illegal, more important was the superior court holding that the court was required to give deference to the factual findings of the Tribunal, and was only permitted to re-open findings of fact in limited circumstances such as breach of natural justice or fraud ${ }^{422}$. As there were no such circumstances here, the findings of fact made by the tribunal were binding on the parties.

While the circumstances are different in each case, the above demonstrate there are alternative ways a courts can approach the facts and the law. The approach should be directed in a principled manner, with regard to the circumstances of the case, and the manner in which the tribunal dealt with it.

\section{E A More Nuanced Test}

Even where the issue is consent, it is not clear how that fact makes any more cogent the argument for de novo review. On the one hand, focusing on the nature of the objection

${ }_{420} A J U v A J T$ [2011] SGCA 41, above note 421 at [40]-[58].

${ }^{421} A J U v A J T$ [2011] SGCA 41, above note 421 at [60].

${ }^{422}$ AJU $v$ AJT [2011] SGCA 41, above note 421 at [65]. 
undoes a substantial platform for the court decision in Dallah - the plain statutory language. On the other hand, all the matters that permit a court to refuse recognition or enforcement are matters that can be said to go the fundamental integrity of the arbitral process.

Court involvement in arbitral proceedings is intended to be limited to only those "safeguards" that are necessary. ${ }^{423}$ In contrast, de novo review inserts the Court into the process as the final arbitrator of fact and law, arguably a function not intended under the New York Convention. There may be some cases where de novo review is warranted, yet a position that starts at de novo review assumes that a Court can only ever decide these fundamental matters. As a matter of principle this over reaches the role of the court and diminishes the role of the arbitral process. De novo review makes decisions of arbitrators merely provisional, and ignores any efficiency gained through the arbitral process, including the effectiveness of competence-competence. ${ }^{424}$

Even where the issue is initial consent, making de novo review the mandatory starting point when enforcement is opposed under (or on grounds analogous to) article V(1)(a) of the New York Convention, neither achieves the objectives of international arbitration nor is necessary to ensure its fundamental integrity. In this respect the decision of the English Court in Dallah is too blunt a tool in the context of the New York Convention. Although a rehearing may be appropriate to some cases, in some circumstances, it should not be the starting point when enforcement is opposed.

Basing the approach to the court's task primarily on the textual interpretation does not work in practice or in theory. As set out above, mandatory de novo review has significant consequences on the conduct of proceedings in practice. Making this the starting point for any proceedings where enforcement is opposed renders much of the convention and broader framework for international arbitration ineffective or redundant. It is also unnecessary.

The structure of the Convention and the distinctions made between articles V (1) (a)-(e) call for a more nuanced approach based, in part, on the nature of the alleged defect. This would be consistent with the specific concerns of the Supreme Court. Although answered

\footnotetext{
${ }^{423}$ See for example the objectives set out in s 1 Arbitration Act 1996 (UK). Though not directly they indicate the limit on court involvement.

${ }^{424}$ Amokura Kawharu “Arbitral Jurisdiction” (2008) 23 New Zealand Universities Law Review 238 at 260.
} 
by reference to distinct touchstones, each was in substance concerned with the question of the arbitrator's jurisdiction, and more specifically, the question of initial consent.

The members of the Supreme Court, and Rix LJ in the Court of Appeal, were firmly focused on the question of whether the Government was properly a party to the arbitration agreement. A focus on the basis for opposing enforcement, as a specific subject (e.g. initial consent), is more appropriate to determining the nature of the court's than high level reliance on a general function, loosely based on the text of the Convention.

On this approach, the grounds on which enforcement are opposed are relevant to the manner in which the court will discharge its function to determine whether the grounds at article $\mathrm{V}$ have been met, In this case, then, when looking at the text of the Convention, the better starting point is to have a base rule, which can be applied consistently to each of the grounds at article $\mathrm{V}$, but is capable of being departed from in certain circumstances. The points of departures would enable a rehearing to occur when the circumstances warrant it, but would ensure this was not the starting point. This of course requires identifying what those base principles might be.

\section{Base Principles}

The function of court at the place of enforcement is to decide whether the party opposing enforcement has discharged the burden of proving one of the grounds under Article V. To give meaningful effect to the New York Convention, and the deliberate shift of the burden of proof, this requires a substantive burden of persuasion. In this respect, there is a subtle, but significant difference from a court starting proceedings as if its role was to undertake an independent inquiry for itself.

Towards this end, the starting point for a court should be a review of the evidence that went before the tribunal. There should be no factual witness or new evidence admitted unless a threshold is met, demonstrating that it is necessary and appropriate in the specific case.

The matters the court should consider before deciding whether evidence is appropriate could include:

a) whether the party opposing enforcement participated in the proceedings, and if so what are the status of those proceedings? 
b) what is the basis on which enforcement is opposed (the ground and the reason that goes to that ground);

c) did the tribunal consider and decide the issue;

d) is there any other reason in the interest of justice to re-hear the matter?

Where a party opposing enforcement participates in the proceedings, a second bite at the cherry should be avoided unless there is good reason. Arguably this is even more so when the basis for opposing enforcement relies on a matter that could have been raised either before the Arbitrator or the supervisory court but wasn't. There is no good policy reason to depart from the usual principles that attach to dilatory tactics and deemed waiver in enforcement proceedings. Further, where a party has participated in proceedings, the conduct of the proceedings at the seat should be considered. There seems to be no principled basis why a party should be in better position at the place of enforcement than before the enforcement court.

Interpretation of the grounds for opposing enforcement are generally agreed to be narrowly drawn. This would suggest at the outset, the issue that is raised as a basis for enforcement would need to be one of sufficient importance to warrant consideration i.e. a manifest case. In this respect the approach of the court could assess the ground by assessing whether, if all the facts alleged by the party opposing enforcement are correct, it would be a basis on which the court might be refused recognition or enforcement.

Where a tribunal has considered and decided the matter, a three stage approach would provide a more flexible approach than the starting point of an independent enquiry:

1. Has the party opposing enforcement, put forward a case that would suggest the court shouldn't give full faith and credit to the award? At this stage an enforcement court's role should be to review's the findings made by the arbitrators, in light of the basis for opposing enforcement, to ascertain whether any finding was unsupported by evidence or was against the weight of the evidence in the light of the Tribunal's assessment of the credibility of the witnesses.

2. Only if the court was satisfied that there was some reason to consider that the award may be unsafe, should the court embark on a more detailed inquiry; 
3. Even when a further enquiry is warranted, there should be a presumption of deference to a tribunal's findings of fact unless they are shown to be clearly wrong or there is some other good reason to re-open them;

4. A high threshold should be required to justify factual witness or new evidence to be called, (either because there has been no first hearing or because the interests of justice otherwise require it).

This approach would better balance the competing issues, recognising arbitration as an autonomous system that is not merely a preliminary step to litigation. It would support the principle of competence competence, and procure potential benefit from the findings and conclusion the tribunal, but leave sufficient flexibility for a court to fulfil its judicial function. In this respect, the court should not be constrained or bound by the arbitrator's findings - but there should be a principled basis for departing from them, based on the case put forward by the party opposing enforcement.

All of the above should sit against a rebuttable presumption that arbitration is the preferred method for resolving international commercial disputes, as the parties want to avoid litigation in national courts, and prefer finality over legal certainty.

\section{A more convincing basis?}

Given the particular facts and circumstances of Dallah, it is hardly surprising the English court's wanted to revisit the tribunal's decision. Comparison with judicial review is unwelcome in the rubric of arbitration generally, and international commercial arbitration especially. However, it is easy to see comparisons with the 'innominate' grounds of judicial review in English law, the idea that something had gone wrong the nature and degree of which required the intervention of the Court.

Viewing the facts through an English lens, the Court was presented with enforcement proceedings against a State, which was a non-signatory, in circumstances where the structure of the agreement envisaged a role for both the State Entity and the State in their independent capacities. This was after an arbitration hearing in which the State did not appear, and where two of the three arbitrators were openly hesitant about the conclusion that was reached. Further, the law that was applied hinted at the controversial theory of 
delocalisation, while the legal basis in the tribunal's decision and subsequent submissions to the court was something of a moving feast.

English Courts do not have a good history of taking a back seat in such cases. Yet these facts did not clearly underpin the reasons in the decision. However, taking into account the above, the Court arguable could have reached the same result on a far more convincing basis.

First, the fact that the Government of Pakistan could demonstrate it did not sign the terms of reference, and only made submissions to the Tribunal on a without prejudice basis, could support the departure from a principle that a court at enforcement will not re-hear matter. In these circumstances, there has been no first hearing, and it may be appropriate for the enforcing court to act as a court at first instance. This generally aligns with the idea that a party who has never taken part in proceedings is more likely to have a genuine basis for claiming the tribunal has no jurisdiction.

Second, at least until the proceedings were in initiated in France, the fact that a French court could and would review all legal and factual matters may have been a reasonable basis for the court not to restrict its approach. Linking the standard of review to be taken by a court at the place of enforcement to the arbitral seat would mean that a party is in no better (or worse) position than under the law governing the contract.

Thirdly, the fact proceedings involved a State non signatory may mean the usual presumption as to arbitration may be rebutted.

Fourthly, where the legal basis on which a non signatory is bound to an agreement is unclear, and when the arbitrators express some hesitation in the conclusion of their awards, a more detailed enquiry by the Court may be justified.

The primary distinction between this approach and one that starts from the basis of a rehearing is flexibility. The court is not bound to revisit a decision of the tribunal unless the circumstances so warrant. Conversely, under Dallah, the Court inserted itself into deciding the legal and factual matters, as a matter of course, whenever enforcement of an award under the New York Convention is opposed.

If Dallah can be read in the context of the facts, making it a high water mark for de novo review, the border incursion may retreat to a border skirmish. 


\section{Conclusion}

Though the Convention leaves a "substantial role" for national law and national courts in this international context, ${ }^{425}$ Dallah highlights the importance of national courts positing principles under the New York Convention firmly in an international context. This is necessary to contribute to the development of autonomous principles capable of broad application, thus ensuring the 'needs of modern practice' continue to be met.

The decision in Dallah should, at best, represent a high-water mark for de novo review. The Supreme Court's reasons for a rehearing are not compelling. There were alternative options to the Court, and those alternatives better balance the intersect between the functions of national courts and the objectives of international arbitration.

Holding that a court at the place of enforcement is always bound to decide a matter de novo neither serves the objectives of international commercial arbitration nor is necessary to promote the fundamental integrity of arbitral proceedings. Instead, it over reaches the role of the Court and diminishes the role of the arbitral process, making decisions of arbitrators merely provisional, and turning a border skirmish a border incursion.

When enforcement is opposed under Article V(1)(a) of the New York Convention, a more nuanced role for a court, can, and should be developed. A more nuanced test is consistent with the language of the New York Convention which does not lend itself well to rules of inflexible application. ${ }^{426}$ That is best achieved by properly giving effect to the requirement that a party opposing recognition or enforcement bears the burden of proof, and giving due regard to the arbitral process.

\footnotetext{
$\overline{425}$ G Born International Commercial Arbitration above n 16 at 95, 101.

${ }^{426}$ G Born International Commercial Arbitration above n 16 at 95, 101 (the substantive components of the New York Convention are set out at Articles I - V).
} 


\section{BIBLIOGRAPHY}

\section{PRIMARY SOURCES}

\section{Conventions}

Treaty concerning the Union of South American States in Respect of Procedural Law (signed at Montevideo, 11 January 1889).

Convention for the Pacific Settlement of International Disputes (opened for signature 29 July 1899, entered into force 4 September 1900).

Convention for the Pacific Settlement of International Disputes (opened for signature 18 October 1907, entered into force 26 January 1910, 1907).

Geneva Protocol on Arbitration Clauses in Commercial Matters 1923 (opened for signature on 24 September 1923, entered into force 28 July 1924).

Geneva Convention for the Execution of Foreign Arbitral Awards of 1927 (opened for signature 26 September 1927, entered into force 25 July 1929).

United Nations Convention on the Recognition and Enforcement of Foreign Arbitral Awards (opened for signature 10 June 1958, entered into force 1959).

United Nations Convention on Contracts for the International Sale of Goods (opened for signature 11 April 1980, entered into force January 1988).

Model Law on International Commercial Arbitration (as adopted by the United Nations Commission on International Trade Law on 21 June 1985, and as amended by the United Nations Commission on International Trade Law on 7 July 2006).

Vienna Convention on the Law of Treaties 1969 (opened for signature 23 May 1969, entered into force 27 January 1980) . 


\section{Legislation}

\section{Australia}

International Arbitration Act 1974 (Aus).

\section{New Zealand}

Arbitration Act 1996

\section{Singapore}

International Arbitration Act (Cap 143A, 2002 Rev Ed)

\section{United Kingdom}

Common Law Procedure Act 185417 \& 18 Victoria 125

Arbitration Act 1950 (14 Geo 6. Ch 27)

Arbitration Act 1979

Arbitration Act 1996

\section{Cases}

\section{Australia}

Altain Khuder LLC v IMC Mining Inc v Anor [2011] VSC 1.

Altain Khuder LLC v IMC Mining Inc v Anor (No. 2) [2011] VSC 12.

IMC Aviation Solutions Pty Ltd v Altain Khuder LLC [2011] VSCA 248.

Resort Condominium International Inc v Bolwell [1995] 1 Qd 406.

\section{Canada}

Mexico v Cargill, Incorporated [2011] ONCA 622.

Seidel v. TELUS Communications Inc. [2011] SCC 15, [2011] 1 S.C.R. 531.

\section{France}

Fondation Albert Abela Family Fondation (AAFF) et. al. v. Fondation Joseph Abela

Family Fondation (JAFF). Case No 08-20,563 (6 October, 2010) (Cour de Cassation).

Gouvernement du Pakistan v Societe Dallah Real Estate \& Tourism Holding Co, Cour d'appel, de Paris, Pôle 1- Ch.1, n 09/28533 (February 17, 2011).

Municipalite de Khoms El Mergeb v Soc Dalico, 20 December 1993, 1994 Rev Arb 116 (Cour de Cassation). 
Société Putrabali Adyamulia v. Société Rena Holding, Cass. le civ., June 29, 2007, 2007 Rev. Arb. 507.

\section{Singapore}

$A J T \vee A J U$ [2010] SGHC 201, [2010] 4 SLR 649.

AJU V AJT [2011] SGCA 41, [2011] 4 SLR 739.

\section{United Kingdom}

$A$ v B [2010] EWHC 3302, [2011] Lloyd's Rep 363.

Aden Refinery Co v Ugland Management Co [1987] Q.B. 650; [1986] 3 WLR. 949;

[1986] 3 All E.R. 737; [1986] 2 Lloyd's Rep.

AES Ust-Kamenogorsk Hydropower Plant LLP Use-Kamenorgorst China

Hydropower Plant JSC [2011] EWCA Civ 647, [2011] WLR (D) 185.

Antaios Compania Naviera S.A v Salen Rederierna A.B (No. 2), [1985] 1 AC 191, [1984] 3 WLR 592 ( "The Antaois").

Anisminic Ltd v Foreign Compensation Commission [1968] 2 QB 862, [1969] 2 A.C 147 (H.L).

Aoot Kalmneft v Glencore International AG [2002] 1 Lloyd's Rep 128.

Astra SA Insurance v Sphere Drake Insurance [2000] 2 Lloyd's Rep 550.

Azov Shipping Co v Baltic Shipping Co (No 1) [1999] 1 Lloyds Rep 68, [1999] All ER 476.

Bremer Vulkan v South India Shipping [1981] 1 AC 909, [1981] 1 All ER 289.

Broda Agro Trade (Cyprus) Limited v Alfred C. Toepfer International Gmbh [2010] EWCA Civ 1100, [2010] WLR (D) 246.

Christopher Brown Ltd $v$ Genossenschaft Osterreichischer Waldbesitzer Holzwirtschaftsbetriebe [1954] 1 Q B. 8.

Chartbrook Ltd v Persimmon Homes Ltd [2009] UKHL 38, [2009] 1 AC 1101.

Czarnikow v Roth Schmidt \& Co [1922] 2 KB 478.

Dallah Real Estate and Tourism Holding Company v The Minister of Religious Affairs, Government of Pakistan [2008] EWHC 1901 (Comm), [2008] 1 All ER 505.

Dallah Real Estate and Tourism Holding Company v The Minister of Religious Affairs, Government of Pakistan [2009] EWCA Civ 755, [2010] 1 WLR 805.

Dallah Real Estate and Tourism Holding Company v The Minister of Religious Affairs, Government of Pakistan [2010] UKSC 46, [2011] 1 AC 763.

Dardana Ltd v Yukos Oil Co. Petroalliance Services Co. Ltd v Same [2002] EWCA Civ 543, [2002] 2 Lloyd's Law Reports 326. 
Dolphin Tanker SRL v Westport Petroleum Inc [2010] EWHC 2617 (Comm), [2011] BUS LR D110.

Electrosteel Castings v Scan-Trans Shipping [2002] EWHC 1993 (Comm), [2003] 1 Lloyd's Rep 190

Fiona Trust v Privalov [2007] EWCA CIV 20, [2008] BUS LR 686, [2008] 1 Lloyds's Rep 254.

Geogas SA v Trammo Gas Ltd (The Baleares) [1993] 1 Lloyd's Rep 215.

Halfdan Grieg \& Co A/S v Sterling Coal and Navigation Co (The Lysland) [1973] QB 843.

Harbour Assurance Co (UK) Ltd v Kansa General International Insurance Co Ltd [1993] 1 QB 701.

Heyman v Darwins Ltd [1942] AC 346.

Jivraj v Hashwani [2010] EWCA Civ 712, [2010] BUS LR 1683, [2010] ICR 1435.

Jivraj v Hashwani [2011] UKSC 40, [2011] 1 WLR 1872.

Lesotho Highlands Development Authority v Impregilo SpA [2005] UKHL 43, [2006] 1 AC 221, [2005] 3 WLR 129, [2005] 3 All ER 789 HL (E).

Manifest Shipping Co Ltd v Uni Polaris Insurance Co Ltd [2001] UKHL 1, [2003] 1 AC 469.

Occidental Exploration Production Co v Republic of Ecuador [2006] EWHC 345 (Comm).

Pearlman v Keepers and Governors of Harrow School. [1979] 1 QB 56, [1978] 2 WLR 736 (CA).

People's Insurance Co of China v Vysanthi Shipping Co [2003] EWHC 1655.

Pioneer Shipping Ltd v B.T.P Tioxide Ltd ("The Nema") [1982] 1 AC 724, [1981] 3 W.L.R 292.

Peterson Farms Inc v C \& M Farming Ltd [2003] EWHC 2298, [2004] 1 Lloyd's Rep 614.

Peterson Farms Inc v C\&M Farming Ltd [2004] EWHC 121 (Comm), [2004] 1 Lloyd's Rep 603.

Premium Nafta Prod Ltd v Fili Shipping Co [2007] UKHL 4019 (U.K), [2007] BUS LR 1719.

Republic of Serbia v Imagesant International NV [2009] EWHC 2853, [2010] 1 Lloyds Rep 324

Scott v Avery 10 ER 1121, (1856) 5. H.L. Cas. 811.

Soleimany v. Soleimany [1999] QB 785, [1998] 3 WLR 811.

Svenska Petroleum Exploration AB v Republic of Lithuania [2005] EWHC 9 (Comm). 
Svenska Petroleum Exploration AB v Republic of Lithuania [2005] EWHC 2437, [2006] 1 All ER (Comm) 731, [2006] 1 Lloyd's Rep 181, [2005] 2 CLC 965.

Svenska Petroleum Exploration AB v Republic of Lithuania [2006] EWCA Civ 1529, [2007] 1 QB 886.

Tajik Aluminium Plant v Hydro Aluminium AS [2006] EWHC 1135 (Comm).

Ust-Kamenogorsk Hydropower Plant JSC (Appellant) $v$ AES Ust-Kamenogorsk Hydropower Plant LLP (Respondent) [2013] UKSC 35, [2013] WLR (D) 232.

West Tankers Inc v Allianz SpA [2009] 1 AC 1138.

Westacre Investments Inc v Jugoimport-SPDR Holding Co Ltd and ors [2000] 1 QB 288 [1999] All ER (D) 486.

Zaporozhye Production Society v Ashley Limited [2002] EWHC 1410 (Comm)

\section{United States of America}

China Minmetals Materials Import and Export Co. Ltd v Chi Mei Corporation $334 \mathrm{~F} 3 \mathrm{~d}$ 274, 288 (2003).

First Options of Chicago, Inc v Kaplan 514 US 938, 944 (1995).

Scherk v Alberto-Culver Co., 417 U.S. 506, 502 n.15 (U.S S.Ct.1974).

\section{SECONDARY SOURCES}

\section{Texts}

van den Berg, A The New York Convention 1958 (1981).

Born, G International Commercial Arbitration (Kluwer Law International, Netherlands, 2009).

Born G, International Arbitration, Cases and Materials (Wolters Kluwer, New York' 2011).

Gaillard, E \& Savage, J (ed) Fouchard Gaillard Goldman on International Commercial Arbitration (Kluwer Law, International, 1999).

Holtzmann, H M and Neuhaus, J E International Commercial Arbitration: Legislative History and Commentary (Kluwer, Boston, 1989). 
Lew, J, Mistelis, L. \& Kroll S., Comparative International Arbitration (Kluwer International, The Hague, 2003)

McLachlan, Campbell Lis Pendens in International Litigation (Martin Nijhoff, Leiden 2009).

Mustill \& Boyd, Commercial Arbitration (Butterworth’s, London, 1982)

Redfern, A \& Hunter, M (eds) Law and Practice of International Commercial Arbitration $\left(4^{\text {th }}\right.$ ed, Sweet and Maxwell, London 2004).

\section{Essays in Books}

Kroll, Stefan "The Arbitration Agreement in Enforcement Proceedings of Foreign Awards" in S. Kroll, L.A. Mistelis, P. Perales Viscasillas \& V. Rogers (eds), Liber Amicorum Eric Bergsten, International Arbitration and International Commercial law: Synergy, Convergence and Evolution, (Kluwer Law International, Great Britain, 2011) 317.

Sanders, P "The Making of the Convention" Enforcing Arbitral Awards under the New York Convention: Experience and Prospects, (UN No. 92-1-133609-0, 1998) at 3.

\section{Journal Articles}

Barceló III, John J "Who decides the Arbitrator's Jurisdiction? Separability and Competence-Competence in Transnational Perspective" (2003) 36 Vanderbilt Journal of Transnational Law 1115.

Berg, van den A "Enforcement of Arbitral Awards Annulled in Russia, Case Comment on Court of Appeal of Amsterdam, April 28, 2009" (2010) Journal of International Arbitration 27(2) 197.

Boyle, Linda R “Three's Company: Examining the Third-Party Problem Through an Analysis of Bridas S.A.P.I.C v Government of Turkmenistan "Problem in Litigation" (2008) Hous L Rev (45) 261. 
Carbonneau, Thomas E "The Exercise of Contract Freedom in the Making of Arbitration Agreements” (2003) 36 V and J. Trannat'l L, 1189.

Cohen, Julius Henry "The Law of Commercial Arbitration and the New York Statute" (1921) Yale Law Journal 147.

Crabtree, James "Responsibility without power: the plight of the arbitrator" (1993) 1(12) International Insurance Law Review 395.

Craig, W. Laurence "Some Trends \& Developments in the Laws and Practice of International Commercial Arbitration” (1995) 30 Tex. Int'1 L.J 1.

Crivellaro "Conflicting Contrasts in Dallah v Government of Pakistan" (2011) 17 Colum. J. Eur. L.F 51.

Delaume, Georges R “United Kingdom: Arbitration Act 1979” (1979) 18 International Legal Materials 1248.

Digby QC, G. John "Is Australia unfriendly to arbitration?" (2012) 7(1) Construction Law International 38 .

Dundas, Hew. R "Recent Developments in English Arbitration Law: Arbitrations Involving Consumers, Whether to Hold a Hearing, Enforcement of Foreign Awards and a Post Script" (2009) 75(1) Arbitration 115.

Dundas, Hew. R "The Pro-Enforcement Assumption of the New York Convention: But...Enforcement of a Foreign Award Refused by English Court of Appeal: Dallah v Pakistan" (2009) 75(4) Arbitration 555.

Dundas, Hew. R "Competence-Competence and the Jurisdiction of the English Courts: the UK Supreme Court Decides - Dallah Real Estate \& Tourism Holding Co v Pakistan" (2011) 77(1) Arbitration 135.

Dundas, Hew. R "Jurisdictional Appeals and Security for Costs: Judicial Conflict Resolved" (2011) 77(2) Arbitration 266. 
Ghikas, Gerald W "A Principled Approach to Adjourning the Decision to Enforce under the Model Law and the New York Convention" Arbitration International (2006) 22, (1) 53.

Grierson, Jacob and Taok, Mirreille "Dallah: Conflicting Judgments from the U.K Supreme Court and the Paris Cour d'Appel “(2011) 28(4) J. Int Arb 407.

Gaillard. Emmanuel, "The Representations of International Arbitration" (2007) 236 (67) New York Law Journal.

Gaillard, Emmanuel "International Arbitration as a Transnational System of Justice - The Next Fifty Years, ICCA Congress Series No. 16, 2012, pp. 66-73.

Gu, Weixia "Judicial Review Over Arbitration in China: Assessing The Extent of the Latest Pro Arbitration Move by the Supreme People's Court in the People's Republic of China" (2009-2010) 27 Wisconsin International Law Journal 221.

Heneghan, Patrick \& Egerton-Peters, Jonathon "Dallah v Pakistan: Vive la différence?" (2011) 6 (3) Global Arbitration Rev. 25.

Hacking, Lord “The Story of the Arbitration Act 1979” (2010) 76 Arbitration 125.

Jaffe, Paul A. C "The Judicial Trend Toward Finality of Commercial Arbitral Awards in England" (1989) 24 Texas International Law Journal 67.

Khanna, Devika "Dallah: The Supreme Court's Positively Pro-Arbitration "No" to Enforcement” (2011) 28 J. of Int'l Arbitration 127.

Kawharu, Amokura "Arbitral Jurisdiction" (2008) 23 New Zealand Universities Law Review 238.

Kolodiej A J "Arbitration Act 1979: Genesis and Operation" (1987) 8(5) Company Lawyer 206.

Landau QC, Toby "United Kingdom: Arbitration Act of 1996" (1996) 35 International Legal Materials 155. 
Lew QC, Julian "Does National Court Involvement Undermine the International Arbitration Process.” (2008-2009) 24 Am. U. Int'1 Rev. 489.

Ma, Winnie (Jo-Mei) "Parallel Proceedings and International Commercial Arbitration: the International law association's Recommendations for Arbitrators" (2009) 2 Contemporary Asian Arbitration Journal 49.

Moss, Giuditta Cordero "Revision of the UNCITRAL Arbitration Rules: Further Steps" (2010) 13 (3) International Arbitration law Review 96.

Mustill, M "The new Lex Mercatoria: The first Twenty Five Years”, (1988) 4 Arbitration International 86.

Nell S.C, Gregory "Recent Developments in the Enforcement of Foreign Arbitral Awards in Australia" (2012) MLLANZ Journal 26 (1) 24.

Park, W. W "Judicial Supervision of Transnational Commercial Arbitration: The English Arbitration Act of 1979” (1980) 21 Harvard International Law Journal 87.

Park W. W "The Lex Loci Arbitri and International Commercial Arbitration” (1983) 32 International and Comparative Law Quarterly 21.

Park, W.W “The Arbitrator's Jurisdiction to Determine Jurisdiction”, in International Arbitration 2006: Back to Basics? (2007) ICCA Congress Series No. 13, 55.

Paulsson, Jan "The Role of Swedish Courts in Transnational Commercial Arbitration" (1980-1981) 21(2) Va. J. Int'1 L 211.

Paulsson, Jan "Delocalisation of International Commercial Arbitration: When and Why it Matters" (1983) 32 International and Comparative Law Quarterly 53.

Rau, Alan Scott "Arbitration and National Courts: Conflict and Co-operation: Understanding (and Misunderstanding) "Primary Jurisdiction" (2010) 21 American Review International Arbitration 47.

Runeland, Per and Blanke, Gordon "Recent Enforcement Cases Under the New York Convention In Europe and the CIS" (2009) 75(4) Arbitration 565. 
Shackleton, Stewart "The Internationalization of English Arbitration law" (2000) 11 (1)

ICC International Court of Arbitration Bulletin Vol. 16.

Willems, Melanie and Ely, Marcus "Dallah v Pakistan - French Courts Uphold the Award" (2011) 5 The Arbiter 3.

\section{Reports}

The Departmental Advisory Committee Report on Arbitration Law 989 ("Mustill Report”)

Lord Mance's Advisory Committee on Section 9 of the Arbitration Act 1996 - First Interim Report on the workings of section 69 of the 1996 Act in regard to maritime arbitrations in London before the Commercial and Admiralty Court.

The Statistical Appendix to the 1993 DAC report on the Special Categories under the Arbitration Act 1979 [1993] 9 Arbitration International 405.

Explanatory Note United Nations on International Trade Law Model Law on International Commercial Arbitration ("Model Law") as adopted by the United Nations Commission on International Trade Law on 21 June 1985 on 7 July 2005 UN doc A/40/17, annex I and A/61/17, annex I)

2013 International Arbitration Survey - Corporate Choices in International Arbitration: School of International Arbitration (SIA), Queen Mary, University of London.

2012 International Arbitration Survey: Current and Preferred Practices in the Arbitral Process, School of International Arbitration (SIA), Queen Mary, University of London.

2006 International Arbitration Study: Corporate Attitudes and Practices School of International Arbitration (SIA), Queen Mary, University of London.

2008 International Arbitration Study Recognition and Enforcement of Foreign Awards School of International Arbitration (SIA), Queen Mary, University of London. 
2010 International Arbitration Survey: Choices in International Arbitration School of International Arbitration (SIA), Queen Mary, University of London.

\section{Internet Materials}

Astigarraga, Jose I. "A Few Words on the Tension between Efficiency and Justice" (2011) Kluwer Arbitration Blog <www.kluwerarbitrationblog.com>.

van den Berg, A "The New York Convention of 1958: An Overview" (2008) ICCA $<$ http://www.arbitration-icca.org/articles.>.

Gary Born and Timothy Lindsay "Enforcement of International Arbitral Awards in England and the New York Convention. (2009) Kluwer Arbitration Blog $<$ www.kluwerarbitrationblog.com>.

Born, Gary "Who is most competent? Some comments on the Allocation of Jurisdictional competence under the English Arbitration Act 1996" (2010) Kluwer Arbitration Blog $<$ www.kluwerarbitrationblog.com>.

Born, Gary "Dallah and the New York Convention" (2011) Kluwer Arbitration Blog $<$ www.kluwerarbitrationblog.com>.

Born, Gary "The Impact of Dallah" (2011) Kluwer Arbitration Blog $<$ www.kluwerarbitrationblog.com>.

Born, Gary "Arbitration Agreements Versus Agency Deference" (2012) Kluwer Arbitration Blog <www.kluwerarbitrationblog.com>.

Bouchardie, Nicholas, Brumpton, Paul, von Krause, Christophe, Seraglini, Christophe and Wheal, Robert "Insight: In Dallah, the Paris Court of Appeal and UK Supreme Court Reach Contrary Decisions Applying Same Law to Same Facts" (2011) White \& Case Newsletters $<$ www.whitecase.com $>$.

Caher, Charlie "Early Impact of Dallah on the English courts" (2011) Commercial Dispute Resolution <www.cdr-news.com>. 
Caher, Charlie and Born, Gary "The Impact of Dallah" (2011) Kluwer Arbitration Blog $<$ www.kluwerarbitrationblog.com>.

Cannon, Andrew "Appeals on a Point of Law in the English Courts: Further Restrictions" (2012) Kluwer Arbitration Blog <www.kluwerarbitrationblog.com>.

Capper, Phillip "Refusing the enforcement of awards - where discretion 'may' be exercised" (2009) Kluwer Arbitration Blog <www.kluwerarbitrationblog.com>.

Chan, Darius "Options Available to An Unsuccessful Party In An Arbitration" (2011) Kluwer Arbitration Blog <www.kluwerarbitrationblog.com>.

Chan, Darius "Singapore Court of appeal re-affirms commitment to minimal intervention of arbitral awards at the intersection of illegality and public policy." (2011) Kluwer Arbitration Blog <www.kluwerarbitrationblog.com>.

Clark, James "Paris Court of Appeal upholds ICC award in Dallah case" (3 March 2011) Practical Law Company <www.practicallaw.com.>

Cowan, Paul "Jivraj v Hashwani - Are Arbitrators Employees?" (2011) Kluwer Arbitration Blog <www.kluwerarbitrationblog.com>.

D’Agnostino, Justin "Impartial: Yes. Neutral: Maybe Not" (2010) Kluwer Arbitration Blog <www.kluwerarbitrationblog.com>.

Davies, Kate "In Defence of Section 69 of the English Arbitration Act" (2010) Kluwer Arbitration Blog <www.kluwerarbitrationblog.com>.

Dawson, Blake, Folie, Alexandra \& Lees, Amanda "Mongolian BBQ: Victorian Court of Appeal fries Mongolian arbitral award (2011) Corporate Lawyers Association of New Zealand $<$ ww.lexology.com.>.

Garcia, Alejandro. L. "Is The Principle of Finality "Losing Its Appeal?" (2010) Kluwer Arbitration Blog <www.kluwerarbitrationblog.com>. 
Gearing, Matthew "The relationship between arbitrators and parties: is the pure status theory dead and buried." (2011) Kluwer Arbitration Blog $<$ www.kluwerarbitrationblog.com>.

George, Martin "Guest Editorial: Hess, Should Arbitration and European Procedural Law be separated or Co-ordinated?" (2010) Conflict of Laws <www.conflictoflaws.net>.

Gold, Marc "Canadian Courts One Year after Seidel: Pro-Arbitration and Still Holding" (2 August 2012) Kluwerblog <http://kluwerarbitrationblog.com>.

Graves, Jack "Court Litigation over Arbitration Agreements: is it Time for a New Default Rule?" (2012) Scholarly Works, Paper 413, Touro Law Centre $<$ http://digitalcommonstourolaw.edu/scholalryworks/413> at 15 .

Holland, Ben and Pendall, Guy "Game, Set and Match" (2011) The Commercial Litigation Journal 5.

Kleiman, Elie \& Spinelli, Julie "Dallah" One Test, Two Different Findings" (30 June 2011) International Law Office $<$ www.internationallawoffice.com.>.

Mcllwraith, Michael "Anti-Arbitration: The Train Has Left The Station" (2011) Kluwer Arbitration Blog <www.kluwerarbitrationblog.com>.

Moses, Margaret "Barring the Courthouse Door? Anti-Suit Injunctions in International Arbitration" (2011) Kluwer Arbitration Blog <www.kluwerarbitrationblog.com>.

Hetherington, Stuart, "Lack of uniformity in international arbitral awards" (2011) mondaq international law $<$ www.modaq.com/australia $>$.

Mallesons Stephen Jacques "Australian court enforces Mongolian award" (20110) Corporate Lawyers Association of New Zealand <www.lexology.com>.

Loukas A. Mistelis, "Is Arbitration Changing" (2009) Kluwer Arbitration Blog $<$ www.kluwerarbitrationblog.com>. 
Paulsson, Jan "Arbitration in Three Dimensions" LSE Law, Society and Economy Working Papers 2/2010 at www.lse.ac.uk/collections/law/wps/wps.hm (text of inagural lecture as Centennial professor at the LSE delivered 24 November 2009)'

Quereshi, Khawar “Too hot to handle?" (2010) New Law Journal 1225 $<$ www.newlawjournal.co.uk>.

Ray, Ashutosh "Dallah v Pakistan: Why The Buzz?" (2010) Lex Arbitri - the Indian Arbitration Blog < www.lexarbitri.blogspot.com>.

Rooney, Adam "Jurisprudence Arbitration update: the approach of the English Courts in Jivraj v Haswani [2010] EWCA Civ 712" (2011) La Lettre du Continentiuex 24 $<$ www.infoclient.gide.com>.

Rooney, Adam “Jurisprudence 2... Dallah Real Estate v Government of Pakistan: or "Put your Trust in Arbitration" (2011) La Lettre du Continentiuex 24 $<$ www.infoclient.gide.com>.

Sheppard, Colin "Guillotined closing oral submissions did not result in a 'serous irregularity' (2007 heck) Colin Sheppard <www.colinsheppard.co.uk>.

Sheppard. Colin "Primacy of Arbitration reemphasized by the House of Lords" (2008 check) Colin Sheppard <www.colinsheppard.co.uk>

Sheppard, Colin 'Requirements for a successful s. 68 'serous irregularity' application reviewed' (2009/2010 check) Colin Sheppard <www.colinsheppard.co.uk>.

Tevendale, Craig "Jivraj v Hashwani - Arbitrators Are Not Employees for the Purposes of Employment Equality" (2011) Kluwer Arbitration Blog $<$ www.kluwerarbitrationblog.com>.

Warren M, "Australia as a "safe and neutral arbitration seat", speaking notes Australian Centre for International Commercial Arbitration's "The Australian Option" Chinese Tour, Shanghai and Beijing, People's Republic of China, 6-7 June 2012.

Whittaker, John \& Friedman Paul "UK: A Challenging Possibility" (11 May 2011), IFLR, <http://www.iflr.com/Article/2836804/UK-A-challenging-possibility.html.>. 


\section{Internet Audio Visual Materials}

Gary Born keynote address at "Border Skirmishes: The Intersection Between Litigation and International Commercial Arbitration" (21 October 2011) University of Missouri School of Law, Centre for the Study of Dispute Resolution 2011 $<$ mms://streaming.missouri.edu/public/law/csdr2011/keynote.wmv>.

ICCA Conference Singapore 2012, International Arbitration: the Coming of a New Age?, Marina Bay Sands Expo and Convention Centre, Singapore (10-13 June 2012) "The relationship between international arbitration and the national judge: both arbitral seat and enforcement; anti-suit and anti-arbitration injunctions; bad faith decisions under the New York Convention; state liability for interfering in the international arbitration process (Breakout Session C2)", (Audio Visual Library Congress Series $<\mathrm{http}$ ://www.arbitration-icca.org/conferences-and-ongresses/ICCA_SINGAPORE_2012video-coverage.html.>)

LSE Arbitration Debate "Unlawful Laws - How far can arbitrators go?" (Pierre Mayer and Jan Paulsson, Moderator: V.V. Veeder), 23 May 2012, $<$ http://www.lse.ac.uk/collections/law/projects/tlp/events.htm.> 